\author{
Universidade de São Paulo \\ Faculdade de Medicina de Ribeirão Preto \\ SETOR DE MASTOLOGIA E ONCOLOGIA GINECOLÓGICA \\ DEPARTAMENTO DE GINECOLOGIA E OBSTETRÍCIA
}

Interação de célula tronco mesenquimal com células de linhagem do câncer de mama e avaliação de seu comportamento biológico

Orientada: Fernanda Marques Rey Orientador: Daniel Guimarães Tiezzi

Ribeirão Preto

2018 
Fernanda Marques Rey

\title{
Interação de célula tronco mesenquimal com células de linhagem do câncer de mama e avaliação de seu comportamento biológico
}

\author{
Tese apresentada à Faculdade \\ de Medicina de Ribeirão Preto \\ da Universidade de São Paulo \\ para obtenção do título de \\ Doutor em Ciências
}

Orientador: Daniel Guimarães Tiezzi

"Versão corrigida. A versão original encontra-se disponível tanto na Biblioteca da Unidade que aloja o Programa, quanto na Biblioteca Digital de Teses e Dissertações da USP (BDTD)"

Ribeirão Preto

2018 


\section{FOLHA DE APROVAÇÃO}

\section{Fernanda Marques Rey}

Interação de célula tronco mesenquimal com células de linhagem do câncer de mama e avaliação de seu comportamento biológico

Tese apresentada à Faculdade de Medicina de

Ribeirão Preto da Universidade de São Paulo para obtenção do título de Doutor em Ciências

Área de concentração: Ginecologia e Obstetrícia 
Aprovado em:

Banca Examinadora

Prof.Dr.

Instituição:

Assinatura:

Prof.Dr.

Instituição:

Assinatura:

Prof.Dr.

Instituição:

Assinatura:

Prof.Dr.

Instituição:

Assinatura: 
Prof.Dr.

Instituição:

Assinatura: 
Autorizo a reprodução e divulgação total ou parcial deste trabalho, por qualquer meio convencional ou eletrônico, para fins de estudo e pesquisa, desde que citada a fonte. 


\section{Ficha Catalográfica}

\section{Rey,Fernanda Marques}

Interação de célula tronco mesenquimal com células de linhagem do câncer de mama e avaliação de seu comportamento biológico

Ribeirão Preto, 2018.

90. : il. ; $30 \mathrm{~cm}$

Tese de Doutorado, apresentada à Faculdade de Medicina de Ribeirão Preto/USP.

Orientador: Daniel Guimarães Tiezzi

1.Câncer de mama 2.Transição epitélio mesenquima

3.Metástase 4.Célula tronco tumoral 


\section{Dedicatória}

Tenho como memória a frase "seu trabalho é estudar", continuo seguindo esse desejo de minha amada mãe Sandra Maria Marques Rey, que me fez filha amada dentro de um verdadeiro lar, agradeço por todo tempo ao seu lado.

Meus pais de coração, os avós Iracema da Silva Pinto e Geraldo Pinto, que me criaram, deram suporte e exemplo para continuar a vida da melhor forma que conseguir, meu coração

é grato por ter vocês em minha passagem. 


\section{Agradecimentos}

Seria injusto agradecer individualmente pessoas que nos ajudam no processo de construção e aprendizado, uma vez que todos os dias aprendemos com pequenos exemplos como é possível fazer a vida ser mais fácil e positiva de ser vivida. Desta forma, os passarinhos que pousam sob meu quintal pela manhã, meus animais de estimação, o porteiro que oferece um bom dia ou responde a um bom dia merecem ser agradecidos nesta tese, então faço aqui, genericamente, e de coração aberto um grande agradecimento as pessoas e acontecimentos que passaram por mim durante o período de construção deste trabalho.

Meu companheiro de jornada, Claudimar Amaro-Jabá, merece especial atenção, estamos juntos há tanto tempo e ao lado dele cresci como jovem adulta a mulher, sou extremamente grata por tê-lo em minha vida.

Ao amigo orientador Daniel Guimarães Tiezzi, que para mim é um exemplo a ser seguido, com idéias e insight sobre ciência e vida, que se faz admirar, um dia chego lá chefe!

Vi um exemplo de bondade e excelência em ciência ao conhecer Dr. José Russo, em meu período fora do país, tenho essa pessoa no coração e certamente seguirei seus exemplos.

Por fim agradeço à FAPESP pelo suporte financeiro durante este doutorado com o processo 2013/04659-7 e pelo apoio financeiro durante o treinamento com a bolsa de estágio em pesquisa no exterior (BEPE) processo 2016/02730-4. 


\section{RESUMO}

O câncer de mama é uma doença heterogênea que é caracterizada por células epiteliais de mama malignas. As células-tronco cancerígenas (CST) no câncer de mama podem aumentar o potencial de agressividade através do tumor. $O$ objetivo deste estudo é avaliar a expansão clonal do microambiente tumoral e a diferenciação celular após o estímulo com células estaminais mesenquimais.

As células MSC derivadas da geléia de Wharton foram co-cultivadas com MCF-7 em proporções de 1\%, 10\%, 30\%.

Após a exposição de MSC junto a MCF-7 com MSC mostrou alteração na localização da proteína e-caderina para o citoplasma e o núcleo. A proteína n-caderina foi deslocada para a membrana, a proteína $\beta$-catenina foi co-localizada no citoplasma e núcleo. Este fenômeno é confirmado por western blot com o aumento dos níveis de proteínas de e-caderina no citoplasma no MCF-7 após o estímulo do MSC. A co-cultura de MCF-7 com MSCs aumenta o número de mamoesferas e influencia o aumento de CD44+/CD24-, esse fenômeno foi possível sob estimulação de 30\% das células MSC. A linhagem celular de câncer de mama MCF-7 em associação com MSC pode aumentar o potencial de agressividade tumoral. Essa interação no microambiente do tumor é determinante para a expansão clonal e diferenciação celular, que são mecanismos relevantes no processo de disseminação metastática.

Palavras-chave: câncer de mama, célula tronco mesenquimal, expansão clonal, MCF- 7 


\section{ABSTRACT}

Breast cancer is a heterogeneous disease that is characterized by malignant breast epithelial cells. Cancer stem cells (CST) in breast cancer can boost a potential for aggressiveness through the tumor. The goal for this study is to evaluated the tumor microenvironment clonal expansion and cellular differentiation after stimulus with mesenchymal stem cells.

MSC cells derived from Wharton's jelly were co-cultured with MCF-7 in proportions $1 \%, 10 \%, 30 \%$.

After the exposure of MSC with MCF-7 showed alteration on localization of the protein e-cadherin to the cytoplasm and nucleus. The protein $\mathrm{n}$-cadherin were displaced predominantly to the membrane, the protein $\beta$-catenin were showed in cytoplasm and nucleus.

This phenomenon is confirmed to western blot with increasing the proteins levels of e-cadherin on cytoplasm in MCF-7 after MSC stimulus. The co-culture of MCF-7 with MSCs increase in the number of mammospheres and influence the increase of CD44+/CD24-, this phenomenon was possible under stimulation of $30 \%$ of MSC cells. The breast cancer cell line MCF-7 in association with MSC can boost a potential for aggressiveness through the tumor. This interaction on tumor microenvironment is determinant for the clonal expansion and cellular differentiation, which are relevant mechanisms in the process of metastatic dissemination.

Keywords: breast cancer, mesenchymal stem cells, clonal expansion, MCF-7 


\section{LISTA DE ILUSTRAÇÕES}

Figura 1: Transição epitélio-mesenquimal e formação de células CD44 /CD24- O fenótipo migratório das células neoplásicas, através do processo de transição epitélio-mesenquimal, confere às células bem diferenciadas características mesenquimais, dando início ao processo de invasão e formação metastática.

Figura 2: Células MCF-7 em cocultura $99 \% \mathrm{MCF} 7+1 \% \mathrm{MSC}$, sob foco 40X,em câmera DIC e FLUO para células com GFP+., é possível identificar e isolar este tipo celular por ser positivo para GFP.

Figura 3: População adquirida em FACS Canto II selecionadas para o perfil GFP+ CD44+CD24- para células MCF-7 e as coculturas 99\%MCF-7+1\%MSC, $90 \% \quad$ MCF-7+10\%MSC e $70 \%$ MCF-7+30\%MSC.

Figura 4: Monocamada de células MCF-7 e coculturas nas proporções $99 \% \mathrm{MCF} 7+1 \% \mathrm{MSC}, \quad 90 \% \quad \mathrm{MCF} 7+10 \% \mathrm{MSC} \quad$ e $\quad 70 \%$ MCF7+30\%MSC, sob foco de microscópio de lentes invertidas de 10X. Avaliação a migração celular coletiva após "scratch"nos tempos de $0,6,18$ e 24 horas até o fechamento da ferida.

Figura 5: Cocultura $99 \% \mathrm{MCF} 7+1 \% \mathrm{MSC}$, sob foco $8 \mathrm{X}$ em lupa. Gel de colágeno 3D sob foco $10 \mathrm{X}$ e em corte $Z$.

Figura 6: Cocultura $90 \%$ MCF $7+10 \%$ MSC sob foco $8 X$, em lupa. Gel de colágeno $3 \mathrm{D}$ sob foco $10 \mathrm{X}$ e em corte $Z$.

Figura 7: Cocultura $70 \%$ MCF7+30\%MSC sob foco $8 \mathrm{X}$ em lupa. Gel de colágeno $3 \mathrm{D}$ sob foco $10 \mathrm{X}$ e em corte $Z$. 
Figura 8: Imagem representativa das colônias formadas pelo ensaio clonogênico após 10 dias de cultivo fotos tiradas em microscópio confocal, realizado "stitching" das imagens.

Figura 9: células MCF-7 expressando GFP e marcadas E-caderina, DAPI com merge de três canais, gráfico da expressão da molécula E-caderina.

Figura 10: células MSC marcadas E-caderina, DAPI com merge de três canais, gráfico da expressão da molécula E-caderina.

Figura 11: cocultura 99\%MCF-7 1\%MSC expressando GFP e marcadas E-caderina, DAPI com merge de três canais, gráfico da expressão da molécula E-caderina.

Figura 12: cocultura 90\%MCF-7 10\%MSC expressando GFP e marcadas E-caderina, DAPI com merge de três canais, gráfico da expressão da molécula E-caderina.

Figura 13: cocultura 70\%MCF-7 30\%MSC expressando GFP e marcadas E-caderina, DAPI com merge de três canais, gráfico da expressão da molécula E-caderina.

Figura 14: cultura MCF-7 marcadas em sequencia GFP+, $\beta$-catenina, DAPI, merge de três canais, gráfico da expressão da molécula E-caderina.

Figura 15: células MSC marcadas em sequencia $\beta$-catenina, DAPI, merge de dois canais, gráfico da expressão da molécula $\beta$-catenina.

Figura 16: cocultura 99\%MCF7 1\%MSC marcadas em sequencia GFP+ ,ß-catenina, DAPI, merge de três canais, gráfico da expressão da molécula $\beta$-catenina. 
Figura 17: cocultura 90\%MCF7 10\%MSC marcadas em sequencia GFP+ ,ß-catenina, DAPI, merge de três canais, gráfico da expressão da molécula $\beta$-catenina.

Figura 18:cocultura 70\%MCF7 30\%MSC marcadas em sequencia GFP+ , $\beta$-catenina, DAPI, merge de três canais, gráfico da expressão da molécula $\beta$-catenina.

Figura 19:cultura MCF7 marcadas em sequencia GFP+,n-caderina, DAPI, merge de três canais, gráfico da expressão da molécula n-caderina.

Figura 20:cultura MSC marcadas em sequencia n-caderina, DAPI, merge de dois canais, gráfico da expressão da molécula n-caderina.

Figura 21:cocultura 99\% MCF7 1\%MSC marcadas em sequencia GFP+,n-caderina, DAPI, merge de três canais, gráfico da expressão da molécula n-caderina.

Figura 22: cocultura 90\% MCF7 10\%MSC marcadas em sequencia GFP+,n-caderina, DAPI, merge de três canais, gráfico da expressão da molécula $n$-caderina.

Figura 23: cocultura $70 \%$ MCF7 $30 \%$ MSC marcadas em sequencia GFP+,n-caderina, DAPI, merge de três canais, ggráfico da expressão da molécula n-caderina.

Figura 24: Camundongo com tumor inserido bilateralmente na quarta mama da fat pad; A: tumor localizado em parede abdominal com inserção de células MCF7; B: tumor com disseminação em parede abdominal, mama e linfonodo com inserção de cocultura $90 \% \mathrm{MCF} 7+10 \% \mathrm{MSC}$.

Figura 25: Reação de imunhistoquímica utilizando o anticorpo antie-caderina. A: tumor de animal do grupo MCF7, com marcação 
forte e focal; B: tumor de animal do grupo no grupo cocultura $90 \%$ MCF7+10\%MSC, com marcação fraco e difuso.

Figura 26: Reação de imunhistoquímica utilizando 0 anticorpo anti-vimentina. A: tumor de animal do grupo MCF7, com marcação negativa; B: tumor de animal do grupo no grupo cocultura $90 \%$ MCF7+10\%MSC, com marcação fraco e focal.

Figura 27: Reação de imunhistoquímica utilizando 0 anticorpo anti-b-catenina. A: tumor de animal do grupo MCF7, com marcação difuso fraco; B: tumor de animal do grupo no grupo cocultura $90 \%$ MCF7+10\%MSC, com marcação forte e difuso.

Figura 28: WB de lise celular MCF-7(total cell) e em sequencia $1 \%, 10 \%$, $30 \%$ e MCF-7 citoplasma para a proteína E-caderina.

\section{LISTA DE GRÁFICOS}

Gráfico 1: Células MCF-7 e em cocultura passadas por citometro de fluxo e adquiridas primeiramente para expressão positiva para GFP, após foram identificadas células que apresentaram o perfil de imunomarcação CD44+ e CD24-. O perfil de expressão foi analisado com o software FlowJo. A análise estatística adotada por análise de variância com pós teste de Tukey.

Gráfico 2: Número de mamoesferas formadas após 10 dias de cultivo em cultura MCF7 e nas coculturas 99\%MCF7+1\%MSC, $90 \%$ MCF $7+10 \% M S C$ e $70 \%$ MCF $7+30 \% M S C$

Gráfico 3: Mamoesferas com o perfil GFP+CD44+CD24- adquirida em FACS Canto II, em células MCF7, MSC e nas coculturas $99 \% \mathrm{MCF} 7+1 \% \mathrm{MSC}, 90 \% \mathrm{MCF} 7+10 \% \mathrm{MSC}$ e $70 \% \mathrm{MCF} 7+30 \%$. Mamoesferas foram contadas, tripsinizadas e passadas por FACs 
para quantificação dos marcadores de superfície celular CD44+/CD24-.

Gráfico 4: Monocamada de células MCF7 e cocultura nas proporções $99 \% \mathrm{MCF} 7+1 \% \mathrm{MSC}, \quad 90 \% \quad \mathrm{MCF} 7+10 \% \mathrm{MSC} \quad$ e $\quad 70 \%$ MCF $7+30 \% \mathrm{MSC}$.

Gráfico 5: Invasão de células MCF-7 em câmara de boyden após 24 horas sob estímulo de meio condicionado de MSC, coculturas e com células e seu meio condicionado. No eixo $X$ as condições quimioatraentes, no eixo $Y$ número de células que passaram pela barreira oferecida pelo matrigel e pela membrana porosa dentro da câmara de boyden.

Gráfico 6: Número de colônias formadas com o ensaio clonogênico. A capacidade de formação de colônias com o estímulo de 30\% de células mesenquimais na cultura de MCF-7 possibilitou aumento no tamanho do número de colônias e diminuição do tamanho das colônias.

Gráfico 7: Número de tumores formados em animais NOD/SCID gamma no grupo MCF-7 e no grupo cocultura $90 \%$ MCF $7+10 \% M S C$ com diferença estatística não significante $\mathrm{p}=0.174$.

Gráfico 8: ensaio de viabilidade MTT utilizando o estímulo do meio condicionado de MSC previamente por 1 hora.

Gráfico 9: Ensaio de viabilidade MTT após o estímulo de uso de $\mathrm{H}_{2} \mathrm{O}_{2}$

Gráfico 10: Ensaio de viabilidade Western Blotting com uso de H2AX para avaliação no dano de DNA. 


\section{LISTA ABREVIATURAS E SIGLAS}

CTT- Células tronco tumorais

ALDH-enzima aldeído dehidrogenase

EMT- transição epitélio-mesenquimal

FACs -fibroblastos associados ao carcinoma

CTM- células tronco mesenquimais

WJ -Geléia de Wharton

CEP -comitê de Ética em Pesquisa

DMEM -Dulbecco's Modified Eagle Medium

PBS- tampão phosphate buffered saline

DFSM -meio livre de soro Mammocult $₫$

BSA -albumina bovina

GFP -proteína fluorescente verde

MTT -methyl-thiazolyl-tetrazolium

WB -Western Blotting

ROS -espécies de oxigênio reativas

$\mathrm{H}_{2} \mathrm{O}_{2}$ - peróxido de hidrogênio

DMSO- Dimetilsulfóxido

RIPA- tampão de extração de proteínas

TBST- tampão Tris-buffered saline

SDS-PAGE- gel de poliacrilamida na presença de SDS

OD- densidade óptica

TBP- box-binding protein

RT-PCR- polimerase via transcriptase reversa em tempo real

FACS- citometria de fluxo ativado por fluorescência 
Sumário

$\begin{array}{ll}\text { RESUMO } & 10\end{array}$

ABSTRACT 11

LISTA DE ILUSTRAÇÕES

LISTA DE GRÁFICOS

LISTA ABREVIATURAS E SIGLAS 16

I INTRODUÇÃO 21

II OBJETIVOS 26

2.1 Objetivo geral 26

III MATERIAL E MÉTODOS 27

3.1 Seleção de pacientes e coleta de cordão umbilical 27

3.2 Cultura primária de MSC. 27

3.3 Citometria de fluxo. 28

3.4 Cocultura. 28

3.5 Teste de migração celular. 28

3.6 Teste de formação de mamoesferas. 29

3.7 Teste de invasão celular pela câmara de Boyden. 29

3.8 Cultura em gel de colágeno 3D. 30

3.9 Imunocitoquímica e imunofluorescência. 31

3.10 Ensaio clonogênico. 31

3.11 Ensaio de viabilidade por MTT 32

3.12 Ensaio de MTT para avaliação da proteção contra a produção de radicais livres e espécies de oxigénio reativas (ROS), induzidos pelo peróxido de hidrogénio $\left(\mathrm{H}_{2} \mathrm{O}_{2}\right)$. 32

3.13 Western Blotting (WB). 33

3.14 Western Blotting (WB) núcleo e citoplasma. 34

3.15 Tumorigenicidade em modelo animal. 34

3.16 Imunohistoquimica. $\quad 34$

3.17 ANÁLISE ESTATÍSTICA 36

IV RESULTADOS 37

4.1 Padronização de cultura primária de MSC. 37

4.2 Cocultura de células MSC e MCF7. 38 
4.3 Migração celular. 38

4.4 Citometria de Fluxo. 41

4.5 Teste de formação de mamoesferas. 42

4.6 Cultura em gel de colágeno 3D. 44

4.7 Tumorigenicidade em modelo animal. $\quad 47$

4.8 Imunohistoquímica. $\quad 49$

4.9 Teste de invasão celular pela câmara de Boyden. 51

4.10 Ensaio clonogênico. 53

4.12 Ensaio de viabilidade por MTT.

4.13 Ensaio de MTT para avaliação da proteção contra a produção de radicais livres e espécies de oxigénio reativas (ROS), induzidos pelo peróxido de hidrogénio $\left(\mathrm{H}_{2} \mathrm{O}_{2}\right)$. 55

4.14 Western Blotting quebra de DNA. 56

4.15 Western Blotting núcleo e citoplasma. 57

4.16 Imunocitoquímica e imunofluorescência. 58

V DISCUSSÃO $\quad 70$

5.1 Mudanças de marcadores celulares 70

5.2 Mudança do perfil de marcadores de superfície celular 74

5.3 Teste de invasão e migração celular por estímulo de MSC e de seu meio condicionado. $\quad 74$

5.4 Aumento do número de mamoesferas e mudança de marcador. 76

5.5 Imunohistoquimica $\quad 77$

5.6 A cultura em gel de colágeno 3D. 78

5.7 Crescimento de colônias na capacidade de proliferação celular 79

5.8 Ensaio de MTT para avaliação da proteção contra a produção de radicais livres e espécies de oxigénio reativas (ROS), induzidos pelo peróxido de hidrogénio $\left(\mathrm{H}_{2} \mathrm{O}_{2}\right)$. 80

5.9 Dano e reparação de DNA em células de câncer de mama em contato com MSC e seu meio condicionado 82

VI CONCLUSÃO 83

Referências Bibliográficas $\quad 84$ 


\section{INTRODUÇÃO}

Estima-se que cerca de 1,7 milhão de novos casos de câncer serão diagnosticados em 2018. O câncer de próstata é o câncer mais comum entre os homens (19\%), seguido por câncer de pulmão (14\%) e colorretal (9\%). Entre as mulheres, os cânceres de mama (30\%), pulmão (13\%) e colorretal (7\%) são os mais comuns (INCA, 2017). Cerca de 522 mil casos de óbito pela doença são reportados todo ano em nosso país. A disseminação metastática é o principal fator relacionado com a morte pela doença (Jemal, Siegel et al. 2010).

Enquanto a variabilidade na etiologia, apresentação da doença, diversidade de tratamento e as condições de saúde fornecem poucos dados para estimativa do prognóstico da doença (Moons et al. 2009), o foco de investigação nas causas, prognóstico e tratamento da doença de forma racional tem se intensificado. A compreensão destas variações que caracterizam o tumor são fundamentais para o desenvolvimento de novas terapias destinadas a atingir com sucesso tumores primários e metastáticos.

O prognóstico está intimamente relacionado com características preditoras na apresentação da doença, sendo a identificação, racionalização e elucidação sistemática de fatores causais relacionados com a piora da configuração da doença os motivos para o aprofundamento da investigação das lacunas na biologia do câncer. A disseminação metastática é o principal fator causal relacionado com a morte pela doença.

Células com capacidade de se espalhar a tecidos adjacentes e formar novas colônias são classificadas como metástases. A invasão a locais distantes e consequente formação de novos sítios micro e macroscópicos de células tumorais é um processo complexo com 
determinantes genéticos e bioquímicos que ainda permanecem incompreendidos(Hanahan \& Weinberg, 2000). Os tumores metastáticos tendem a crescer em múltiplos focos em órgãos distantes e são difíceis de remover cirurgicamente ou por irradiação. Estas células cancerígenas metastáticas são frequentemente resistentes ao tratamento com drogas quimioterapêuticas (Karlsson et al., 2017). Os quimioteráticos utilizados têm como alvo células tumorais em crescimento e com capacidade proliferativa, em vez de sua capacidade de se disseminar e crescer em locais distantes, que são as propriedades características das células cancerígenas metastáticas (Massagué et al. 2017).

Hanahan \& Weinberg, 2000 desenvolveram o modelo classificado como "The Hallmarks of Cancer", no qual os autores classificam os fatores causais para o desenvolvimento e progresso do câncer, com alterações essenciais que ditariam o crescimento e colonização do câncer. Os autores explicitam como a capacidade de invasão e metástase permite às células cancerígenas escaparem da massa tumoral primária e colonizarem novos sítios no corpo onde, pelo menos inicialmente, os nutrientes e o espaço não são limitantes. As metástases recém-formadas surgem como amálgamas de células cancerígenas e células de suporte normais recrutadas a partir do tecido do hospedeiro (Hanahan \& Weinberg, 2000).

Dentre os marcos causais para o desenvolvimento do câncer, especificamente investigamos a capacidade de invasão e metástase para o prognóstico do câncer

O processo metastático é entendido como uma cascata, para o sucesso deste processo complexo e necessário que células cancerígenas percorram determinado caminho sistemático que se iniciaria com invasão local; intravasamento de células cancerosas em vasos sanguíneos e linfáticos próximos; extravasamento de células cancerígenas a tecidos distantes; formação secundária tumoral e por formação de tumores macroscópicos. Sendo a invasão e metástase 
extremamente complexo e ainda incompletamente incompreendido (Hanahan \& Weinberg, 2000)

Dentre o conjunto de células cancerígenas lançadas à circulação, o completo sucesso de metástase é alcançado em menor número, e a explicação plausível para este fenômeno vêm que a população tumoral possua perfil heterogêneo, sendo necessário apenas uma pequena população a assumirem o potencial metastático. A heterogeneidade tumoral, em que células de uma mesma neoplasia apresentam diferentes capacidades funcionais e proliferativas, bem como se encontram em diferentes estágios de diferenciação (Reya, Morrison et al. 2001, Campbell and Polyak 2007), está intimamente relacionada com a hipótese para explicar a falha no tratamento da doença e a disseminação metastática (Razzak, Lin et al. 2008).

O modelo hierárquico, onde diferentes subpopulações no tumor exercem diferentes atividades biológicas tem sido proposto após a identificação de uma população de células com capacidade de iniciação e auto- renovação tanto em neoplasias hematológicas como em tumores sólidos (Nowell 1976).

O processo em múltiplos estágios de uma célula cancerígena que venha a se destacar do nicho primário, migrando e invadindo tecidos adjacentes é classificado como processo de transição epitélio mesenquima (EMT). O processo de EMT se explica por perda de adesão célula-célula, com remodelação da morfologia celular e capacidades funcionais. A medida que ocorra estímulo, células com características epiteliais, modificam sua configuração, agora com formato fusiforme para a repopulação de tecidos distantes. Ao final da repopulação, estas mesmas células reassumem sua função outrora estabelecida, retornando ao seu estado epitelial, este processo é chamado transição mesenquimal a epitelial (MET).

A plasticidade celular conferida pelo processo EMT e MET é essencial para manutenção fisiológica e homeostática do corpo. Células mesenquimais assumem esta função em manter o tecido homeostase, 
bem como para regenerar o tecido após danos. Estas células com perfil tronco tem a potencialidade de auto- renovação, repopulação e podem permanecer em estado quiescente por anos (Hanahan \& Weinberg, 2000.

A indução da EMT em células cancerígenas resulta em, mesmo que a curto período o fenótipo tronco celular com as mesmas capacidades adquiridas por células mesenquimais. Estes dados conferem a potencialidade para a EMT, o que origina as células com alta capacidade de migração e invasão, identificadas como células tronco tumorais (CTTs) (Mani, Guo et al. 2008).

$O$ entendimento de fatores e mecanismos que intensifiquem 0 potencial metastático ainda permanecem pouco compreendidos, sendo então uma real necessidade a intensificação no estudo da biologia tumoral.

Células tronco tumorais (CTT) no câncer de mama podem ser identificadas pela expressão de proteínas de membrana celular. A citometria de fluxo é utilizada para fenotipagem e caracterização desta população. A subpopulação de células ESA+/CD44+/CD24- tem uma alta capacidade de iniciação e auto-renovação tumoral no carcinoma de mama (Al-Hajj, Wicha et al. 2003).

A presença de CTTs nos carcinomas invasivos é muito variável. $\mathrm{Na}$ linhagem celular MCF-7, a ocorrência de células CD44+/CD24- não chega a $1 \%$. Na linhagem metastática MDA-MB-231 essa taxa chega até $90 \%$. Abraham BK et al analisaram a prevalência de células CD44+/CD24- no câncer de mama utilizando imunohistoquímica com dupla marcação e observaram uma variação de 0\% a 80\% (Abraham, Fritz et al. 2005). A variação na quantidade de CTT está intimamente relacionada com a capacidade de disseminação metastática bem como na resistência ao tratamento sistêmico no câncer de mama (Kasimir-Bauer, Hoffmann et al. 2012)

O perfil tronco celular descrito anteriormente por Al-Hajj e cols pode ser modulado. Mani e cols demonstraram que a expressão de 
fatores de transcrição (Twist1 e Snail) que estão envolvidos na indução da transição epitélio-mesenquimal (EMT) podem induzir um fenótipo tronco celular em linhagens de células imortalizadas do tecido mamário e que essa modificação fenotípica em células transformadas aumenta a capacidade de gerar tumores em modelos xenográficos (Al-Hajj, Wicha et al. 2003, Mani, Guo et al. 2008). Esses dados sugerem que a EMT é um importante processo molecular responsável pelo que chamamos de plasticidade celular.

A indução da EMT em células malignas culmina com fenótipo tronco celular com alta capacidade de promoção da doença maligna. Estes dados demonstram uma potencial ligação entre a EMT, que dá origem a células com capacidade de migração e invasão, com as células com propriedades de CTTs (Mani, Guo et al. 2008). Como alguns estudos têm demonstrado que a EMT aumenta o potencial tumorigênico de células de carcinoma (Hugo, Ackland et al. 2007), existe uma hipótese de que as CTTs não são uma entidade distinta, mas sim, células tumorais que transitoriamente adquirem propriedades de "stem cells" em conseqüência da EMT. Este modelo mostra a influência da EMT na progressão do câncer (Figura 1). 


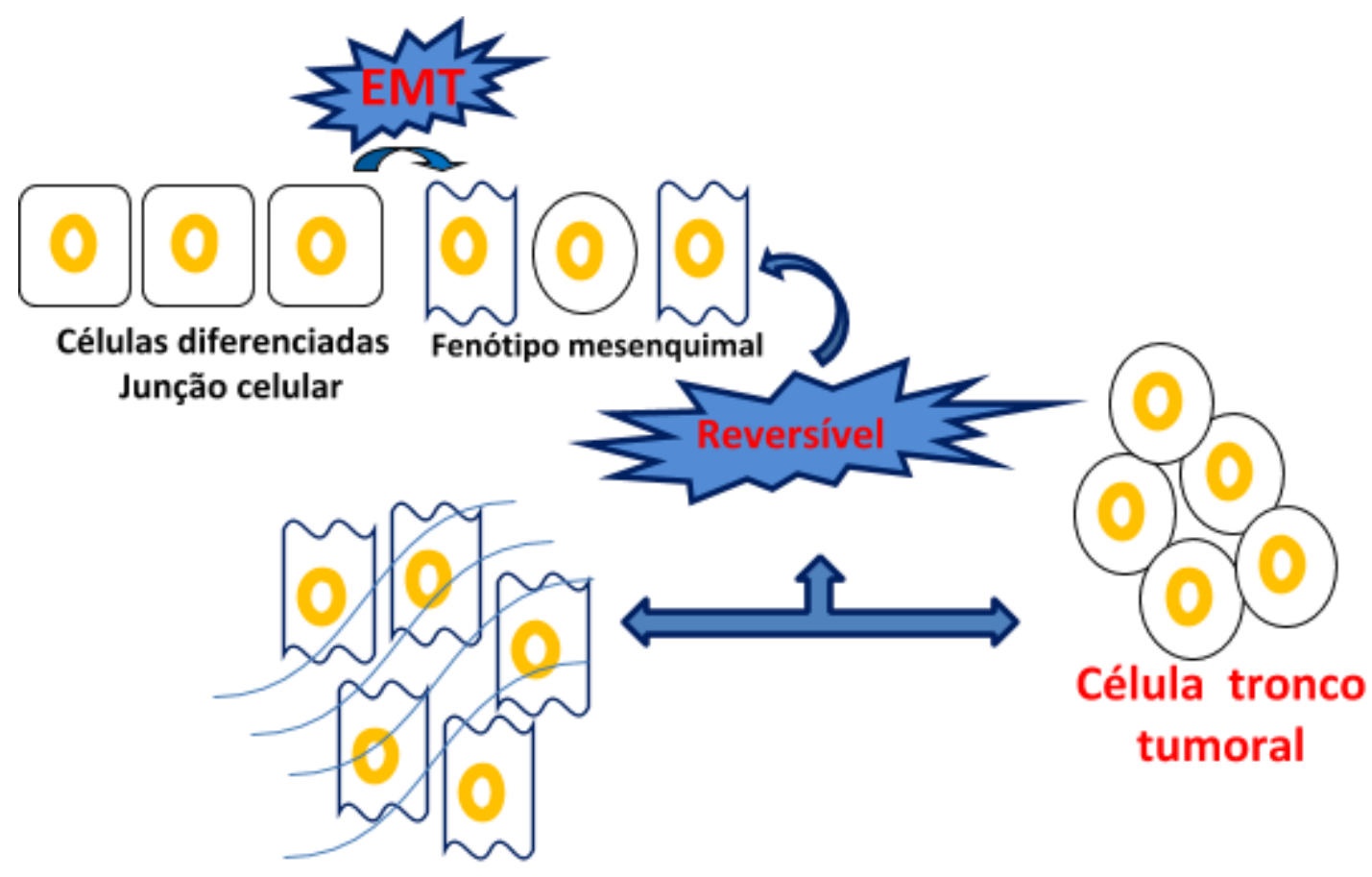

Célula tronco mesenquimal

Figura 1: Transição epitélio-mesenquimal e formação de células CD44/CD24- O fenótipo migratório das células neoplásicas, através do processo de transição epitélio-mesenquimal, confere às células bem diferenciadas características mesenquimais, dando início ao processo de invasão e formação metastática.

A ocorrência de EMT durante a progressão do tumor permite às células do tumor ainda não invasivo, adquirir a capacidade de infiltrar os tecidos vizinhos e conseqüentemente enviar metástases para locais distantes. A evidência mais convincente para o envolvimento de EMT na oncogênese é a capacidade dos reguladores EMT de induzir uma agressividade tumoral (Thiery 2002).

Uma observação cada vez mais evidente é a de que a expressão reduzida de genes envolvidos na adesão e comunicação célula-célula provavelmente está participando na promoção do processo de invasão e, por outro lado, a re-expressão desses genes é fundamental para a sobrevivência e nova adesão do processo metastático (Cowin, Rowlands et al. 2005). Assim, o processo de formação metastático possivelmente é determinado por vias de sinalização que controlam a re-expressão de 
genes relacionados com a adesão e comunicação célula-célula (Sheridan, Kishimoto et al. 2006)

A existência de células tronco tumorais no câncer de mama pode impulsionar um potencial de agressividade ao tumor. A sua interação ao microambiente tumoral é determinante na expansão clonal e diferenciação celular, os quais são mecanismos relevantes no processo de disseminação metastática (Albini and Sporn 2007, Liu, Ginestier et al. 2011).

Células tronco mesenquimais (CTM) ou do inglês mesenquimal stem cells (MSCs) são originárias do estroma tumoral e têm grande importância na carcinogênese de tumores sólidos, criando um microambiente favorável para a iniciação, promoção e progressão tumoral (Bhowmick, Neilson et al. 2004, Mueller and Fusenig 2004).

A diferenciação MSCs em fibroblastos associados ao carcinoma têm uma grande importância na neovascularização tumoral (Orimo, Gupta et al. 2005), controle da transição epitélio mesenquimal (EMT) (Radisky, Levy et al. 2005), modulação da resposta imune contra o tumor, instabilidade genética (Djouad, Plence et al. 2003, Radisky, Levy et al. 2005), e na síntese, deposição e remodelação da matriz extracelular (ECM) (Bhowmick, Neilson et al. 2004). Adicionalmente, estudos in vitro têm demonstrado uma influência do estroma na dinâmica de células tronco tumorais em tumores sólidos incluindo o câncer de mama (Huang, Li et al. 2010).

CTMs são definidas como células multipotentes, que podem ser isoladas e diferenciadas, formando distintos grupos celulares (Uccelli, Moretta et al. 2008). Células primitivas mesenquimais possuem a habilidade de expansão na cultura celular a qual remetem aspectos fisiológicos a um estado celular naïve (Troyer and Weiss 2008). Durante o desenvolvimento embrionário, MSCs provindas do mesênquima embrionário, são capazes da diferenciação e formação de outros tecidos como: ósseo, cartilaginoso, adiposo, entre outros (Troyer and Weiss 2008). 
A presença de MSCs em tecido humano saudável torna possível a renovação e reconstituição celular focal. Células mesenquimais podem ser selecionadas a partir da geléia de Wharton (WJ) do cordão umbilical humano, sendo uma forma interessante de utilização e cultivo deste tipo celular, uma vez que é relativamente fácil a coleta e o processamento da WJ do cordão umbilical (Mitchell, Weiss et al. 2003).

A associação de células tronco mesenquimais humanas (MSCs) a células de linhagem tumoral pode promover a observação de um fenômeno tumorigênico, pela interação celular, onde células tronco mesenquimais podem, pela indução da EMT, tornar possível um fenótipo mais agressivo às células de linhagem tumoral e com características tronco mesenquimais (Thiery 2002).

A capacidade invasiva de células tumorais na mama pode ser explicada pelo fato da presença de células pluripotentes no tecido, contribuem para a agressividade do tumor sólido, resta entender como o comportamento celular ocorre diante das alterações celulares adquiridas a partir do contato a células MCF-7 em cocultura com MSCs, possibilitando desta forma o entendimento dos mecanismos envolvendo o comportamento celular e molecular do câncer.

O entendimento da integração do tumor maligno e o estroma se torna um foco de estudo para avaliação do comportamento celular e molecular no câncer, na citoquimiotaxia e consequente agressividade da resposta de interação destes subtipos celulares envolvidos com o crescimento da população tumoral. 


\section{OBJETIVOS}

\subsection{Objetivo geral}

O objetivo principal do estudo é avaliar a influência da presença de células tronco mesenquimais em co-cultura com células do carcinoma de mama humano MCF-7, promoção e progressão da doença em modelos in vitro e in vivo.

\subsection{Objetivos específicos:}

1. Estudar os efeitos da cocultura de MSCs e da linhagem celular MCF-7 na:

a - porcentagem de células CD44+/CD24-;

b - capacidade de invasão e migração celular in vitro;

c - capacidade de formação de mamoesferas in vitro;

d.- capacidade de formação de colônias em cultura 2D e em gel de colágeno em 3D;

e - capacidade de proliferação e viabilidade;

f - capacidade de proteção a ROS;

g - proteção ao dano de DNA;

2. Estudo in vivo da capacidade de geração de tumores (tumorigenicidade) com células MCF-7 e em cocultura de CTMs e MCF-7 em modelos animais;

3. Análise de tecidos tumorais por imunohistoquímica;

4. Análise de tumores por imunocitoquímica. 


\section{MATERIAL E MÉTODOS}

\subsection{Seleção de pacientes e coleta de cordão umbilical.}

Foram convidadas a participar mulheres com idade entre 18 a 35 anos, independente da raça ou classe social, no pré-parto do Centro Obstétrico do Hospital das Clínicas da Faculdade de Medicina de Ribeirão Preto. Foram coletados quatro cordões umbilicais (cerca de $10 \mathrm{~cm}$ ) de mulheres após o parto, e mantidos sob condições assépticas até o extração das células da geléia de Wharton. Este projeto tem aprovação do Comitê de Ética em Pesquisa (CEP) do Hospital das Clínicas da FMRP-USP, processo HCRP no 053810/2012 parecer no 161.004. Todas as pacientes assinaram o termo de consentimento livre e esclarecido.

\subsection{Cultura primária de MSC.}

Após obtenção do cordão umbilical, no centro obstétrico do Hospital das Clínicas da Faculdade de Medicina de Ribeirão Preto USP, o cordão coletado foi transportado e mantido em solução salina estéril, a temperatura de $2^{\circ} \mathrm{C}$ até a remoção de WJ. Resumidamente o cordão foi dissecado, separado da veia e artérias e com lâmina de bisturi triturado em fragmentos de $1 \mathrm{~mm}$ sob uma placa de Petri úmida com meio (MTH - 1x Hanks +15mM HEPES pH 7,4 $+5 \%$ de soro fetal bovino). A WJ triturada foi digerida com solução de $1 \mathrm{mg} / \mathrm{ml}$ de Colagenase tipo IV, incubada em banho maria à $37^{\circ} \mathrm{C}$ por 20 minutos.

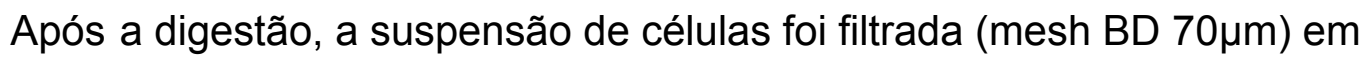
um tubo tipo falcon $50 \mathrm{ml}$ e lavada com PBS. Posteriormente as células são sedimentadas por centrifugação a $1100 \mathrm{rpm}$ à $4^{\circ} \mathrm{C}$ por 5 minutos. $\mathrm{O}$ sobrenadante é desprezado e o pellet de células é ressuspendido em 4000 $\mu$ l de Minimum Essential Medium (aMEN) suplementado com $20 \%$ de soro fetal bovino, $1 \% \mathrm{~L}$ - glutamina, $1 \%$ penicilina, $1 \%$ anfotericina $B$, $1 \%$ HEPES (protocolo modificado). Após os fragmentos digeridos foram semeados em placa de cultura celular com 6 poços (Costar, NY), com meio Dulbecco's Modified Eagle Medium (DMEM) (Invitrogen, Carlsbad, 
CA, E.U.A.) suplementado com $10 \%$ de soro fetal bovino (Sigma Aldrich, St Louis, MO, E.U.A.), 1\% L-glutamina (Invitrogen, Carsbad, CA, USA) , $1 \%$ de penicilina (Sigma Aldrich) até completarem confluência de $80 \%$. Após confluência, o poço foi lavado com PBS, ou solução salina, incubado com tripsina $0,25 \%$ (Sigma Aldrich, St Louis, MO, E.U.A) por aproximados 3 minutos ou até descolamento do conteúdo celular do poço. O conteúdo de cada 2 poços foi transferido para um tubo tipo falcon de $15 \mathrm{ml}$, igualado com igual volume de meio DMEM e centrifugado a $1100 \mathrm{rpm}$ à $4^{\circ} \mathrm{C}$ por 5 minutos. O sobrenadante foi

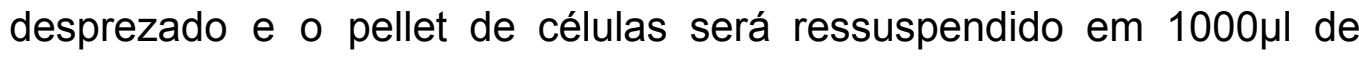
Dulbecco's Modified Eagle Medium (DMEM) (Invitrogen , Carlsbad, CA, E.U.A.), suplementado com $10 \%$ de soro fetal bovino (Sigma Aldrich, St Louis, MO, E.U.A.), 1\% L-glutamina (Invitrogen, Carsbad, CA, USA) 1\% de penicilina (Sigma Aldrich) semeado em garrafa de $25 \mathrm{~cm}^{2}$ mantida em estufa umidificada à $37^{\circ} \mathrm{C}$ com $5 \%$ de $\mathrm{CO}_{2}$. Este protocolo foi desenvolvido e adaptado para este projeto. Após a segunda passagem, o pellet de células foi encaminhado a Fundação Hemocentro de Ribeirão Preto, onde as células foram adquiridas em FACS Canto II (BD Biosciences, San Jose, CA), passadas por um painel de imunomarcadores de superfície celular para confirmação da identidade das células tronco mesenquimais, para isso, a população utilizada neste trabalho apresentou expressão positiva de: CD90, CD73 e CD45 e ausência de expressão de: CD45, CD34, CD14, CD11b, CD79a, CD19 e HLA-Dr, conforme recomendação adotada pela sociedade internacional de terapia celular (Dominici et al., 2006). Os protocolos a seguir foram realizados em colaboração junto ao departamento de biologia celular na faculdade de medicina da USP de Ribeirão Preto, no laboratório da professora Dra. Enilza Maria Espreafico e nas facilities da Universidade de São Paulo campus Ribeirão Preto. 


\subsection{Cocultura.}

Células MCF-7 foram compradas pelo ATCC (Manassas, Virgínia, EUA) expressando o marcador fluorescente GFP. Células foram semeadas em meio Dulbecco's Modified Eagle Medium (DMEM) (Invitrogen , Carlsbad , CA, E.U.A.) suplementado com $10 \%$ de soro fetal bovino (Sigma Aldrich, St Louis, MO, E.U.A.), 1\% L-glutamina (Invitrogen, Carsbad, CA, USA), 1\% de penicilina (Sigma Aldrich) em garrafas de culturas de $25 \mathrm{~cm}^{2}$ na proporção de $99 \% \mathrm{MCF} 7+1 \% \mathrm{MSC}$, $90 \%$ MCF $7+10 \%$ MSC e $70 \%$ MCF $7+30 \%$ MSC para 200.000 células e mantidas à $37^{\circ} \mathrm{C}$ com $5 \%$ de $\mathrm{CO}_{2}$ por 5 dias. Em seguida os ensaios de citometria de fluxo, migração celular, formação de esferas, colágeno 3D e tumorigenicidade animal foram realizados.

\subsection{Citometria de fluxo.}

As células tumorais MCF-7 em cocultura com MSC foram quantificadas para CD44+/CD24- com anticorpos anti-CD44 (APC)(BD Biosciences) e anti-CD24 (PE) (BD Biosciences) com protocolo adotado conforme recomendação do fabricante. Resumidamente, após incubação com os anticorpos, as amostras foram lavadas 2 vezes com PBS, e centrifugadas a $1.100 \mathrm{rpm}$ por 10 minutos. As células foram adquiridas em FACS Canto II (BD Biosciences, San Jose, CA) e as análises foram feitas usando o software FlowJo (TreeStar, USA).

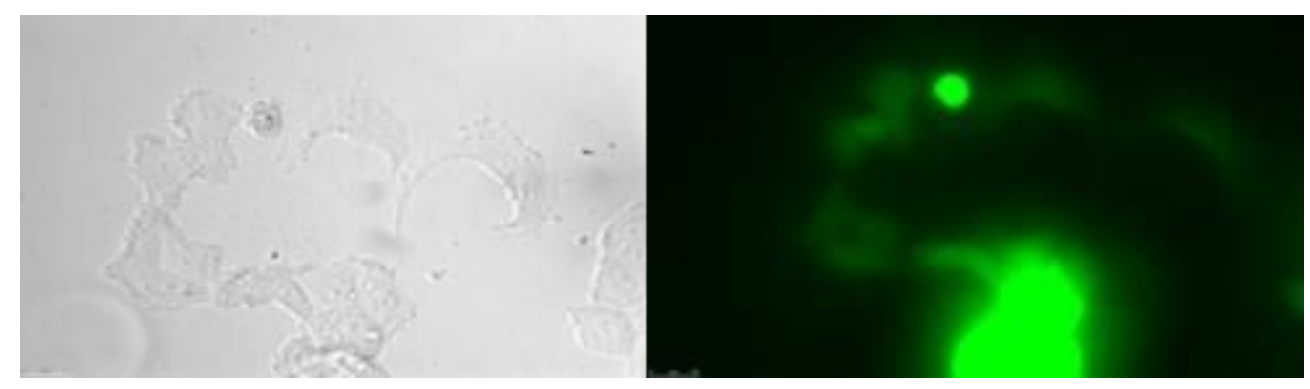

Figura 2: Células MCF-7 em cocultura 99\%MCF7+1\%MSC, sob foco 40X,em câmera DIC e FLUO para células com GFP+., é possível identificar e isolar este tipo celular por ser positivo para GFP. 


\subsection{Teste de formação de mamoesferas.}

O estudo de formação de mamoesferas foi baseando-se no artigo de Shaw et al, 2012. Após cinco dias de cocultura entre MCF7 e MSC, foram semeadas 10.000 células em um poço de placas de cultura (24-poços) de ultra-baixa aderência em meio livre de soro (DFSM) Mammocult $₫$ (Stem Cell Technologies) e mantidas a cultura por dez dias quando o número de esferas formadas foram quantificadas. O meio com esferas foi centrifugado a $300 \mathrm{~g}$ por $3 \mathrm{~min}$. Após o pellet foi ressuspendido

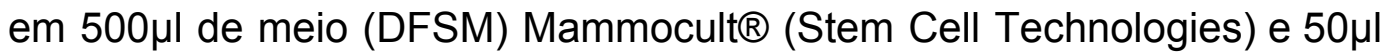
da solução celular foi colocada em um poço de uma placa de 96 poços, sendo então contadas as esferas. O valor encontrado multiplicado por 10. Após a contagem das esferas, elas foram dissociadas utilizando solução com tripsina $0,025 \%$ e realizado citometria de fluxo para análise de quantidade de células CD44+/CD24-.

\subsection{Teste de migração celular.}

O estudo de migração celular foi baseado no protocolo adotado por Karnoub et al, 2007. Células MCF7 em cocultura 99\% de MCF7 $+1 \%$ de MSC, $90 \%$ de MCF7 $+10 \%$ de MSC e $70 \%$ de MCF7 $+30 \%$ de MSC foram, tripsinizadas e semeadas em placas de 24 poços para 50.000 células totais. Após confluência do poço, as células foram estorvadas por 24 horas com redução de SBF em seu meio de cultivo e então os poços foram lavados com PBS 1X e duas linhas em formato de cruz foram traçadas sob o poço que serviram como marco das áreas a serem fotografadas. As linhas foram traçadas com ponteira P100 (Oxigen), células aderidas foram fotografadas em objetiva de 10X de microscópio de lentes invertidas no tempo de 0 hora, 6 horas, 18 horas e 24 horas para avaliação da migração celular. 


\subsection{Teste de invasão celular pela câmara de Boyden.}

O protocolo adotado para este experimento foi utilizado no trabalho de Chen, 2005. Células Tripsinizadas foram contadas e mantidas em

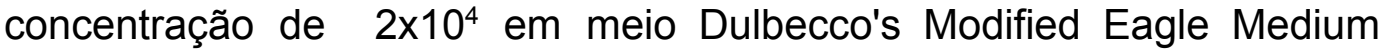
(DMEM) (Invitrogen, Carlsbad, CA, E.U.A.) para células MCF-7 e as coculturas 99\% MCF7+ 1\% MSC, 90\% MCF7+ 10\% MSC e $70 \%$ MCF $7+30 \%$ MSC suplementadas com $1 \%$ de penicilina (Sigma Aldrich). A câmara de Boyden (48 wells \#AP48, Neuroprobe, USA) foi limpa com água a seca com papel limpo. Foi colocado $27 \mu \mathrm{L}$ de meio condicionado na câmara inferior. Após foi posicionado sob os poços a membrana semi permeável poros de $8 \mu \mathrm{M}$ previamente recoberto com matrigel (Becton Dickinson) e acoplado à câmara superior, fechando com roscas. Foi adicionado $50 \mu \mathrm{L}$ da solução de células na câmara superior. Foi cultivado por $24 \mathrm{~h}$ e mantida em estufa umidificada à $37^{\circ} \mathrm{C}$ com $5 \%$ de $\mathrm{CO}_{2}$. Após as $24 \mathrm{~h}$, foi retirado a membrana, retirado o excedente de matrigel e meio de células contido na parte superior da membrana com auxílio de uma espátula tipo wiber embebida em PBS. Foi realizado coloração com Diff Quick em placa de petri, fixado com metanol gelado $100 \%$ e corado com cristal de violeta. As células que atravessaram a membrana foram fotografadas sob lente de microscópio invertido 40X e contadas para determinar a capacidade de invasão.

\subsection{Cultura em gel de colágeno 3D.}

Baseado no protocolo adotado por Tadashi et al, 1996, foi realizado o experimento tridimensional em colágeno de cauda de rato tipo I (Sigma-Aldrich, USA) 3mg/ml. O colágeno foi misturado a $12 \mathrm{mM} \mathrm{HCL}$, proporcional a 8 volumes, formando um colágeno ácido, posteriormente esta solução foi misturada a 1 volume de meio Dulbecco's Modified Eagle Medium (DMEM) (Invitrogen, Carlsbad, CA, E.U.A.) suplementado com 4,5g/l de D-Glucose (Biochrom, Germany) e neutralizado com 1M NaOH. Acrescentamos 1 volume do meio Dulbecco's Modified Eagle Medium (DMEM)(Invitrogen , Carlsbad , CA, E.U.A.) suplementado com 10\% de 
soro fetal bovino (Sigma Aldrich, St Louis, MO, E.U.A.), 1\% de penicilina (Sigma Aldrich, USA), mantendo essa solução em gelo . Posteriormente $450 \mu l$ desta solução de colágeno gel foi pipetada em poço de placas de cultura (24-poços) e incubada em estufa úmida a $37^{\circ} \mathrm{C}$ com $5 \%$ de $\mathrm{CO}_{2}$ por 30 minutos para gelificação. Células em coculturas na proporção de 99\%MCF7+1\%MSC, $90 \%$ MCF $7+10 \%$ MSC e $70 \%$ MCF $7+30 \%$ MSC foram utilizadas neste experimento, $250 \mu \mathrm{l}$ da solução celular com colágeno foi colocado por poço na proporção de 4000 células por poço. Foi avaliada a configuração de invasão celular no gel de colágeno e a morfologia celular neste complexo até o sétimo dia por microscopia invertida e fotos com plano $Z$.

\subsection{Ensaio clonogênico.}

Para o ensaio clonogênico, foi adotado o protocolo utilizado por Franken et al, 2006. Foram semeadas 500 células MSC, MCF-7 e em cocultura 99\% MCF7+ 1\% MSC, 90\% MCF7 + 10\% MSC e $70 \%$ MCF $7+30 \% M S C$ em placas de cultura celular de 6 poços (KASVI), com área de crescimento de $9,60 \mathrm{~cm}^{2}$, mantidas em meio Dulbecco's Modified Eagle Medium (DMEM) (Invitrogen, Carlsbad, CA, E.U.A.), suplementado com $10 \%$ de soro fetal bovino (Sigma Aldrich, St Louis, MO, E.U.A.), $1 \%$ L-glutamina (Invitrogen, Carsbad, CA, USA), 1\% de penicilina (Sigma Aldrich) e mantidas em cultura por período variável de 7 a 13 dias, enquanto e possível distinguir as colônias. Após este período placas foram fotografadas em microscópio confocal Eletromicroscópio Leica SP8 sob foco 10X, foram mensuradas colônias de células MCF-7 baseando-se em seu formato e quantidade de colônias, distinguindo-as por expressar o marcador fluorescente GFP. Este ensaio foi realizado em colaboração no laboratório do Prof. Dr. José Russo, no Fox Chase Cancer Center, Filadélfia, USA. 


\subsection{Imunocitoquímica e imunofluorescência.}

O protocolo utilizado para este experimento foi retirado e modificado pelas recomendações do fabricante Thermo Fisher. Células MSC, MCF7 e em cocultura 99\%MCF7+1\%MSC, 90\%MCF7+10\%MSC e $70 \%$ MCF $7+30 \%$ MSC foram tripsinizadas e semeadas sob lamínulas em placas de 24 poços para 50.000 células totais. Após confluência do poço e lamínulas, o meio de cultura foi aspirado e as células fixadas com paraformaldeído $4 \%$ por 20 minutos à temperatura ambiente. Em seguida, as lamínulas foram lavadas e as células permeabilizadas com $0,5 \%$ de Triton X-100 por 5 minutos. Foi realizado bloqueio da biotina endógena com $2 \%$ soro albumina bovina (BSA9647) (Sigma, EUA) por 2 horas. A marcação com os anticorpos primários e-caderina, vimentina e b-catenina e n-caderina foi executado com incubação por 2 horas. Após as lamínulas foram lavadas e incubadas com o anticorpo secundário, Alexa-Fluor 594, 488 (Thermo Fisher Scientific). As lamínulas foram montadas com a fluoromount conjugado com o fluorófero DAPI (Sigma-Aldrich) seladas e mantidas sob temperatura de 2 a $8^{\circ} \mathrm{C}$ até a realização de fotografias em microscópio multifoton LSM780, AxioObserver (Carl Zeiss).

\subsection{Western Blotting (WB) núcleo e citoplasma.}

Para realização foi utilizado o kit NER-PER ${ }^{\mathrm{TM}}$ (Thermo Fisher) e adotado protocolo recomendado pelo fabricante. Células MCF-7 em cocultura foram recolhidas por sorting. Brevemente células $2 \times 10^{6}$ células foram coletadas e lavadas com PBS a $500 \times \mathrm{g}$ durante 3 minutos, recolhendo o sobrenadante, deixando o sedimento celular, adicionando o reagente de extração citoplasmática I (CERI), reagente de extração citoplasmática II (CERII) e o reagente de extração nuclear (NER) com centrifugação e recolhimento do sobrenadante para extração das proteínas citoplasmática e nuclear. Após este passo seguiu-se para a quantificação das proteínas, fracionamento das proteínas da amostra em um gel de poliacrilamida, transferências dessas proteínas para 
membrana, incubação da membrana com anticorpo E-caderina 1:4000, GAPDH como controle endógeno 1:2000 a fim de avaliar a presença desta proteína em célula total e nas porções citoplasmáticas e nucleares. Este ensaio foi realizado em colaboração no laboratório do Prof. Dr. José Russo, no Fox Chase Cancer Center, Filadélfia, USA.

\subsection{Western Blotting (WB)}

Baseando-se no protocolo adotado por Ji el al. , 2017, foi realizado o teste para avaliação $H 2 A X$ fosforilada $(\gamma-H 2 A X)$. Para realização do teste de WB foi necessário realizar alguns passos: extração e quantificação das proteínas; fracionamento das proteínas da amostra em um gel de poliacrilamida; transferências dessas proteínas para uma membrana; incubação da membrana com um anticorpo para detectar a proteína específica a ser analisada e revelação dessa membrana para análise dos dados. Após cultivo celular as culturas foram tripsinizadas, descartado o sobrenadante e acrescentado o tampão de lise RIPA e inibidor de protease, sendo armazenado em ultra-freezer $-80^{\circ} \mathrm{C}$ até utilização das amostras. Após as amostras foram descongeladas rapidamente e foi utilizado anticorpo que detecção da histona $\mathrm{y}-\mathrm{H} 2 \mathrm{AX}$ fosforilada, para avaliar o nível de quebras de DNA (Watters, Smart et al. 2009). Inicialmente as amostras proteicas de culturas celulares MSC, MCF-7 e coculturas $99 \%$ MCF $7+1 \%$ MSC, $90 \%$ MCF $7+10 \%$ MSC e $70 \%$ MCF $7+30 \% M S C$ foram separadas por eletroforese em gel de poliacrilamida na presença de SDS (SDS-PAGE) e transferidas para membrana de nitrocelulose. A membrana foi bloqueada com tampão TBST (TBS 1X, 0,25\% Tween-20) contendo $5 \%$ de leite desnatado a temperatura ambiente por 30 minutos sob agitação. Em seguida, a membrana foi incubada por 1 hora em temperatura ambiente na presença de anticorpos anti-y-H2AX (ABCAM, ab11174) diluído em TBST 1:2000 e em consonância foi feito em outro gel de poliacrilamida, para a reação com o anticorpo anti-tubulina (Sigma 041M4798), diluído em TBST 
1:10000 como controle de carregamento, com incubação dos anticorpos primários por 1 hora em temperatura ambiente. Após esta incubação, as amostras foram lavadas com tampão contendo $5 \%$ de leite desnatado por 5 vezes e posteriormente os anticorpos secundários anti- mouse IgG (ABCAM, Ab-6789), diluído em TBST 1:10000 por 1 hora em temperatura ambiente. Por fim, a membrana foi tratada com reagentes quimioluminescentes e exposta a filme autorradiográfico para avaliação de quebra de DNA.

\subsection{Ensaio de viabilidade por MTT.}

A viabilidade celular foi medida utilizando o 3-(4,5 dimetiltiazol-2-il) bromide- 2,5 difenil tetrazólio MTT, com seguimento de protocolo recomendado pela empresa $\mathrm{ATCC}^{\mathrm{TM}}$.Foram semeadas 500 células MSC, MCF7 e em cocultura 99\%MCF7+1\%MSC, 90\%MCF7+10\%MSC e $70 \%$ MCF7+30\%MSC em placas de 96 poços. Após confluência, as células foram pré tratadas durante 24 horas com os meios de cultivos retirados das culturas de MSC, e das coculturas em 1\% MSC, 10\% MSC e 30\% MSC. As células foram lavadas com PBS ( $\mathrm{pH} 7.4$ ), adicionado de $180 \mathrm{~mL}$ DMEM e $20 \mu \mathrm{l}$ de solução de MTT $(5 \mathrm{mg} / \mathrm{ml})$ em cada poço e as

células foram incubadas durante 4 horas a $37^{\circ} \mathrm{C}$ em $5 \%$ de $\mathrm{CO}_{2}$ com a solução de MTT (Wang and Huang 2005). No final da incubação, o sobrenadante foi rejeitado e os cristais de formazan insolúveis foram dissolvidos em 100 ul de DMSO. A densidade óptica (OD) em cada poço foi medida a $570 \mathrm{~nm}$ no espectrofotometro. 
3.14 Ensaio de MTT para avaliação da proteção contra a produção de radicais livres e espécies de oxigênio reativas (ROS), induzidos pelo peróxido de hidrogénio $\left(\mathrm{H}_{2} \mathrm{O}_{2}\right)$.

As culturas foram tratadas com o mesmo protocolo adotado por MTT listado acima. Após as culturas foram expostas a $300 \mu \mathrm{mol}$ de $\mathrm{H}_{2} \mathrm{O}_{2} / \mathrm{L}$ durante uma hora. A placa foi lavada com PBS $(\mathrm{pH} 7.4)$, adicionado de $180 \mathrm{~mL}$ de DMEM e 20 ul de solução de MTT $(5 \mathrm{mg} / \mathrm{ml})$ em cada poço e então as células foram então incubadas durante 4 horas a $37^{\circ} \mathrm{C}$ em $5 \%$ de $\mathrm{CO}_{2}$ Células que não estiveram expostas a $\mathrm{H}_{2} \mathrm{O}_{2}$ foram incubadas nas mesmas condições que tratado. No final da incubação, o sobrenadante foi rejeitado e os cristais de formazan insolúveis foram dissolvidos em $100 \mu \mathrm{l}$ de DMSO. A densidade óptica (OD) em cada poço foi medida em $570 \mathrm{~nm}$ espectrofotómetro abs.

\subsection{Tumorigenicidade em modelo animal.}

Dezoito camundongos fêmea NOD/SCID com 10 meses foram utilizados para a resposta com injeção de células tumorais. Os animais foram divididos em grupos de avaliação da tumorigenicidade: animais com cocultura celular de $90 \%$ MCF $7+10 \%$ MSC e animais com células MCF-7 na concentração de $1 \times 10^{6}$ células por animal. Os animais foram anestesiados com $0,3 \mathrm{~mL}$ de Ketamina+Xilazina. A suspensão de células foi injetada na quarta mama da (fat pad) e os animais avaliados pelo período de 5 meses até formação de tumor sendo então sacrificados com super dose de anestésico. Os tumores foram coletados e foi realizada avaliação histológica nos diferentes grupos de animais.

\subsection{Imunohistoquimica.}

Os cortes histológicos parafinados passaram por um processo de desidratação com alcoóis em diferentes concentrações, diafanização com xilol (Merck, BR). Em seguida, foi realizada a recuperação antigênica com calor úmido, em banho-maria histológico à temperatura de $96^{\circ}$ a $98^{\circ} \mathrm{C}$ por 40 minutos. A recuperação antigênica foi padronizada, buscando-se 0 
melhor tampão a ser utilizado, que neste caso foi o tampão tris-EDTA (Tris(hydroxymethyl)aminomethane-EthylenediamineTetraacetic Acid) (Merck, BR) pH 9 com 0,05\% de Tween 20 (Across Organics, EUA). Ao término do procedimento para a recuperação antigênica, os cortes foram hidratados com solução PBS pH 7,4 e tratados com solução composta por $50 \%$ metanol (Merck, BR), 50\% PBS por 10 minutos, para inativação da peroxidase endógena. Em seguida, estes cortes foram incubados por 18 horas em câmara úmida à temperatura ambiente, com os anticorpos diluídos em PBS pH 7.4. Foram utilizados os anticorpos E-Cadherin (Thermo Scientific) na diluição 1:500, Beta-Catenin: (DAKO) na diluição: 1:100 e Vimentin (Biocare Medical) na diluição: 1:200. O sistema de amplificação empregado foi o Mach4 Universal HRP-Polymer Detection System (Biocare Medical, USA). Em seguida, o tecido foi lavado com PBS pH 7.4 com 0,05\% Tween 20 e incubado com o anticorpo secundário anti-camundongo isotipo lgG $(\mathrm{H}+\mathrm{L})$, feito em cavalo (cód. BA-2000 Vector Laboratories, UK), na diluição 1:200 por 1 hora em temperatura ambiente. Após a incubação, o tecido foi lavado com PBS pH $7.4 \mathrm{com}$ 0,05\% Tween 20 e incubado com o complexo avidina-biotina-peroxidase $(A B C)$ (Novocastra, UK) por 50 minutos em temperatura ambiente. A revelação foi realizada com o cromógeno 3,3 diaminobenzidina (DAB) (Sigma, EUA), misturado com 0,95\% peróxido de hidrogênio (H2O2) 30 volumes (Tec-Lab, BR) por 3 minutos à temperatura ambiente. A reação foi interrompida lavando o tecido com água destilada. A contracoloração foi feita com Hematoxilina de Harris. Em seguida, o tecido passou pelo processo de desidratação com alcoóis em diferentes concentrações e diafanização com xilol e finalmente a montagem da lamínula foi realizada em meio não aquoso com solução tolueno denominada Permount (Fisher Scientific, EUA). Como controle positivo da reação foi utilizado tumores de próstata do banco de tumores do departamento de patologia FMRP-USP. A leitura das lâminas foi feita por três examinadores de forma aleatória e "cega" em microscopia óptica comum. A reação foi avaliada de forma semi-quantificada em cruzes onde reações negativas (0) com o perfil de 
ausência de coloração nas células foram analisadas como marcação negativa, reações fracas $(0 /+e+)$ com o perfil de reação de fraca intensidade e focal e difusa foram analisadas em um mesmo grupo como marcação fraca $(+\mathrm{e}++)$ e reações moderadas e fortes $(++\mathrm{e}+++)$ com o perfil moderada intensidade e difusa e ou forte intensidade e focal foram analisadas em um mesmo grupo como marcação forte.

\subsection{ANÁLISE ESTATÍSTICA}

A análise estatística foi realizada utilizando o software GraphPad Prism 6 com análise de variância utilizando One-Way (ANOVA) e pós-teste Tukey's para todos os testes em exceção a análise de marcação por imunohistoquimica que foi utilizado o teste chi-square e ao ensaio de migração celular que foi adotado o teste Kruskal-Wallis e pós teste Dunns. Os dados foram apresentados como média \pm desvio padrão. Foram considerados níveis de significância de $p \leq 5 \%$. 


\section{RESULTADOS}

\subsection{Citometria de Fluxo.}

Células MSC foram cultivadas até a passagem 3 e semeadas em triplicata em placa de cultura celular de 6 poços e então cocultivadas com células MCF-7 nas proporções 99\%MCF $7+1 \% \mathrm{MSC}, \quad 90 \%$ MCF $7+10 \%$ MSC e $70 \%$ MCF $7+30 \%$ MSC e por fim $100 \%$ de MSC e $100 \%$ de MCF-7, mantidas à $37^{\circ} \mathrm{C}$ com $5 \%$ de $\mathrm{CO}_{2}$ por 5 dias. Foram quantificadas as células CD44+/CD24-com anticorpos anti CD44(APC) e anti-CD24 (PE), conforme figura 3.
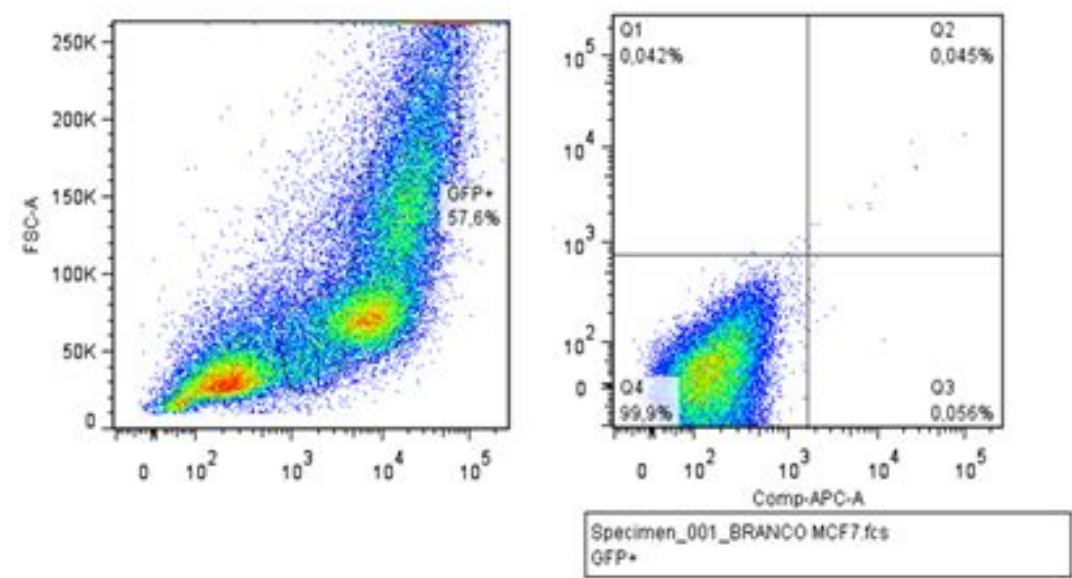

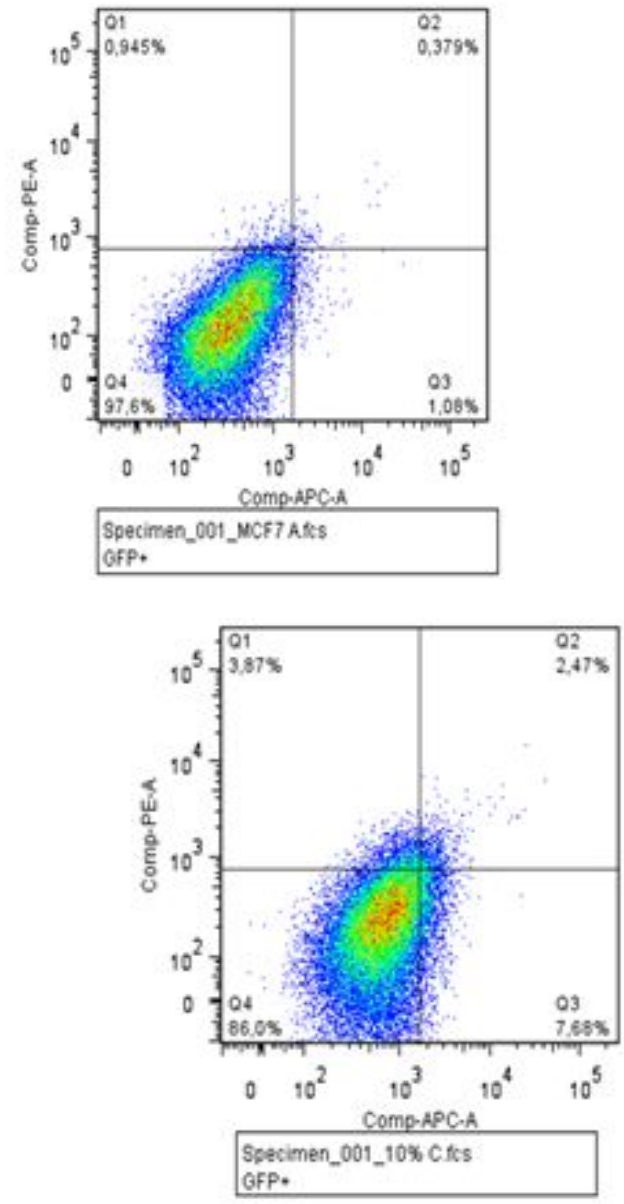
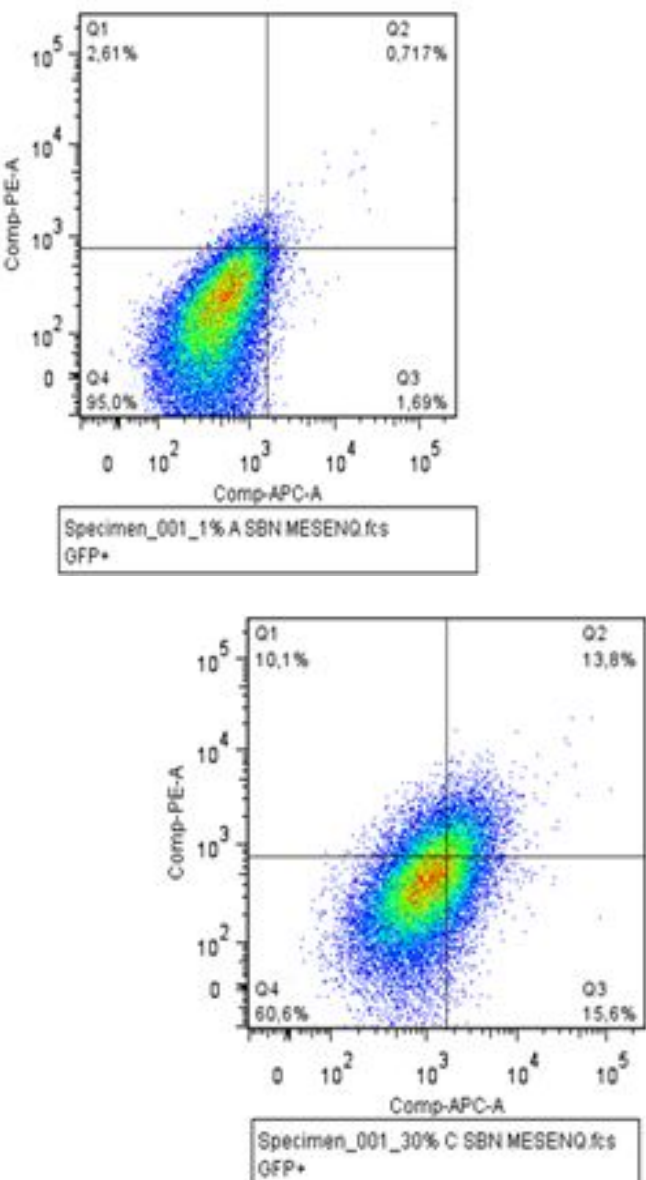

Figura 3: População adquirida em FACS Canto II selecionadas para o perfil GFP+ CD44+CD24para células MCF-7 e as coculturas 99\%MCF-7+1\%MSC, 90\% MCF-7+10\%MSC e $70 \%$ MCF-7+30\%MSC. 


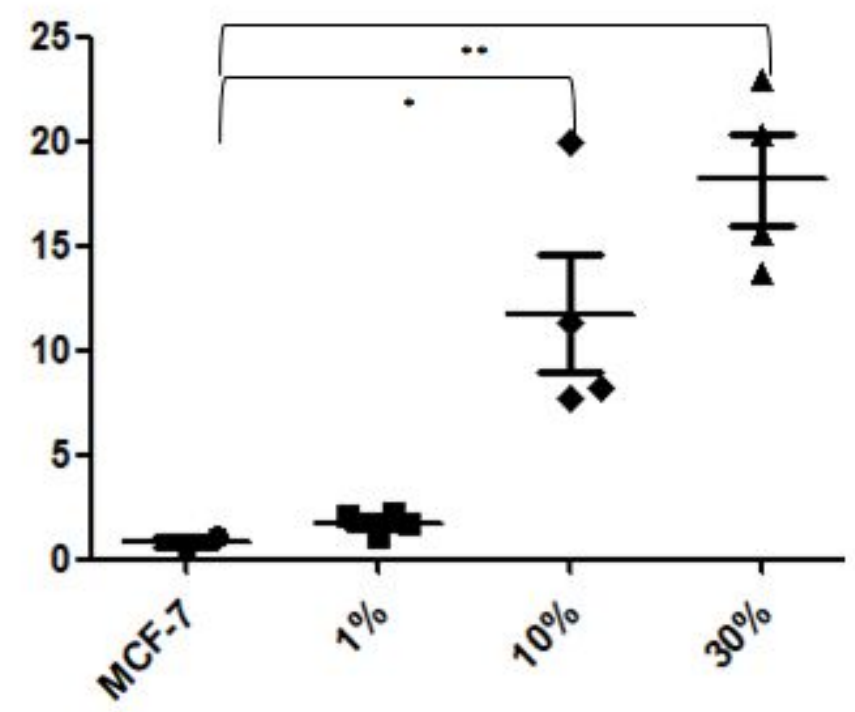

Gráfico 1: Células MCF-7 e em cocultura passadas por citometro de fluxo e adquiridas primeiramente para expressão positiva para GFP, após foram identificadas células que apresentaram o perfil de imunomarcação CD44+ e CD24-. O perfil de expressão foi analisado com o software FlowJo. A análise estatística adotada por análise de variância com pós teste de Tukey.

O gráfico 1 representa a análise das culturas de MSC e MCF-7 e das coculturas com células MCF-7 e MSC nas proporções 99\%MCF-7+1\%MSC, $90 \%$ MCF-7+10\%MSC e $70 \%$ MCF-7+30\%MSC.

Foi obtido resultado significativo quantificando células com perfil CD44+/CD24- comparados MCF-7 e à cocultura de 10\% MSC+ 90\% MCF-7 (95\% Cl of diff $-21,25$ to $-0,6186)$ e $30 \%$ MSC+ $70 \%$ MCF-7 (95\% $\mathrm{Cl}$ of diff-27,64 to $-7,011)$.

\subsection{Teste de formação de mamoesferas.}

Foram realizadas avaliações em duplicatas para avaliação de formação de mamoesferas, mantidas até o décimo dia de cultivo, suplementando o meio de cultivo com meio Mammocult $\circledast$ (Stem Cell Technologies) a cada 3 dias de incubação. Foi observada diferença significante na formação de mamoesferas em células controle MCF-7 
quando comparadas ao número de mamoesferas formadas em coculturas após cultivo por 10 dias. No gráfico 2 obtivemos resultado significativo sob o número de quantificação de mamoesferas MCF-7 vs $10 \% p<$ $0.001(95 \% \mathrm{Cl}$ of diff -141.5 to -31.00$)$, MCF-7 vs $30 \% \% \mathrm{p}<0.05(95 \% \mathrm{Cl}$ of diff -127.8 to -17.25$), 1 \%$ vs $10 \% p<0.05(95 \% \mathrm{Cl}$ of diff -114.0 to $-3.499)$, MCF-7 vs $1 \%, 1 \%$ vs $30 \%, 10 \%$ vs $30 \%$ não apresentaram diferenças significativas.

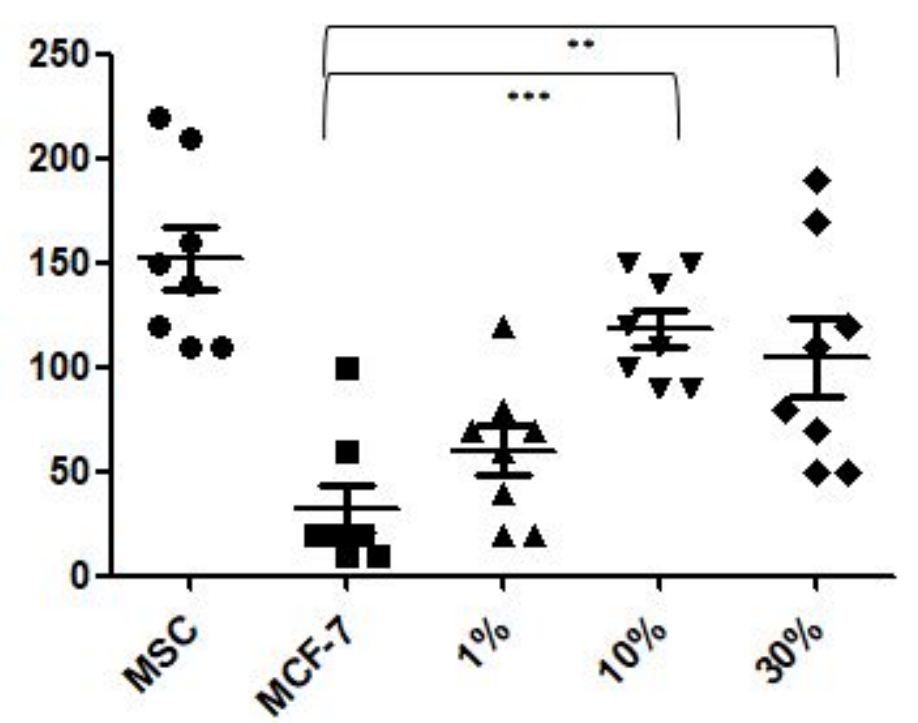

Gráfico 2: Número de mamoesferas formadas após 10 dias de cultivo em cultura MCF7 e nas coculturas $99 \% \mathrm{MCF} 7+1 \% \mathrm{MSC}, 90 \% \mathrm{MCF} 7+10 \% \mathrm{MSC}$ e $70 \% \mathrm{MCF} 7+30 \% \mathrm{MSC}$

As mamoesferas foram quantificadas para o perfil CD44+/CD24com anticorpos anti-CD44 (APC) e anti-CD24 (PE) por citometria de fluxo.

Foi quantificado o perfil CD44+/CD24- nas mamoesferas previamente contadas como mostra o gráfico 3 . Houve mudanças no perfil de expressão na cocultura 1, 10 e $30 \%$ de MSC quando comparada com a cultura de MCF-7 isoladamente, todas as coculturas apresentaram mudanças significativas no perfil de marcação celular CD44+/CD24- após influência de MSC na cultura. Juntamente com os dados de número de esferóides, aqui células MCF-7 GFP+ adquiridas em FACs apresentaram perfil de membrana característico para CTT após serem cultivadas na presença de células mesenquimais. 


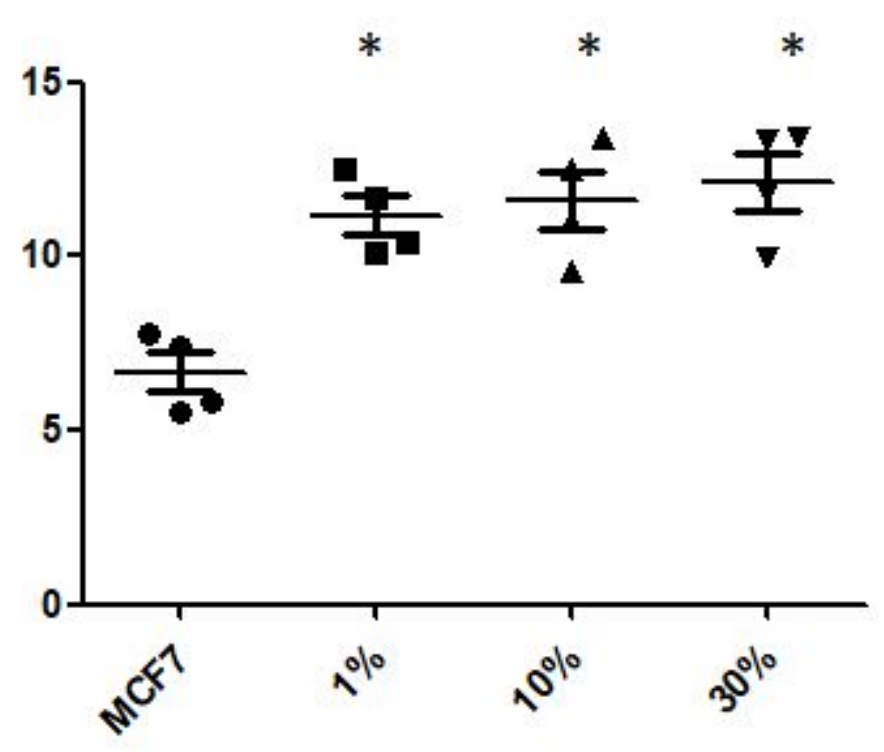

Gráfico 3: Mamoesferas com o perfil GFP+CD44+CD24- adquirida em FACS Canto II, em células MCF7, MSC e nas coculturas 99\%MCF7+1\%MSC, 90\% MCF7+10\%MSC e $70 \%$ MCF7+30\%. Mamoesferas foram contadas, tripsinizadas e passadas por FACs para quantificação dos marcadores de superfície celular CD44+/CD24-.

\subsection{Migração celular.}

Foram realizadas avaliações em triplicata das áreas de fechamento da ferida induzida pelo teste de Wound Healing. A mensuração da área de preenchimento celular foi analisada utilizando o software ImageJ. Foi possível analisar as alterações fenotípicas e tempo médio de migração decorrente da cultura celular da célula controle MCF-7, das coculturas e da célula MCF-7 sob influência de migração de meio de cultivo de célula mesenquimal com 5 dias de administração de meio de cultivo, como mostrado na Figura 4 e gráfico 4.

A influência da presença de células mesenquimais cocultivadas com células MCF-7 apresentou diferenças no tempo de fechamento da ferida produzida pelo teste de $\mathrm{WH}$, sendo maior a migração celular em todos estímulos com $1 \%, 10 \%$ e $30 \%$ de células mesenquimais cocultivadas com MCF-7 ou apenas sob influência do meio condicionado de MSC quando comparados à migração de MCF-7 cultivada em condições normais 


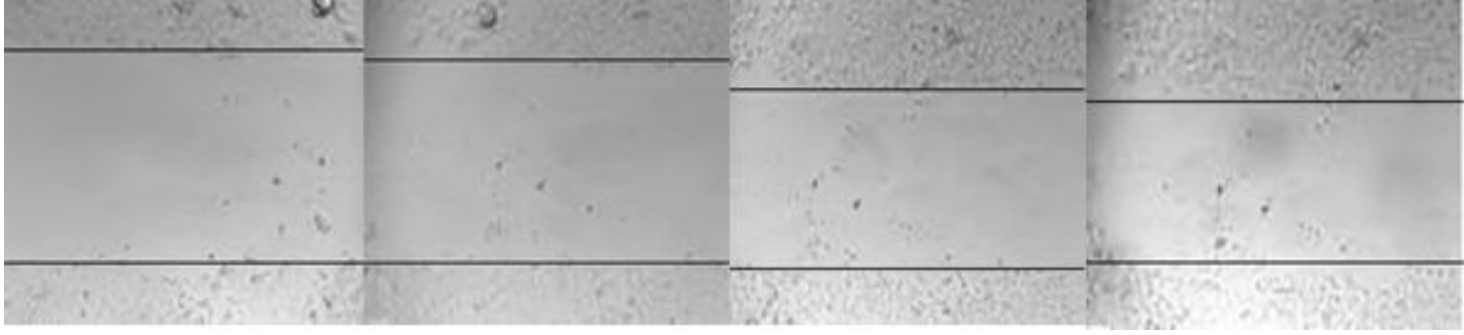

MCF-7

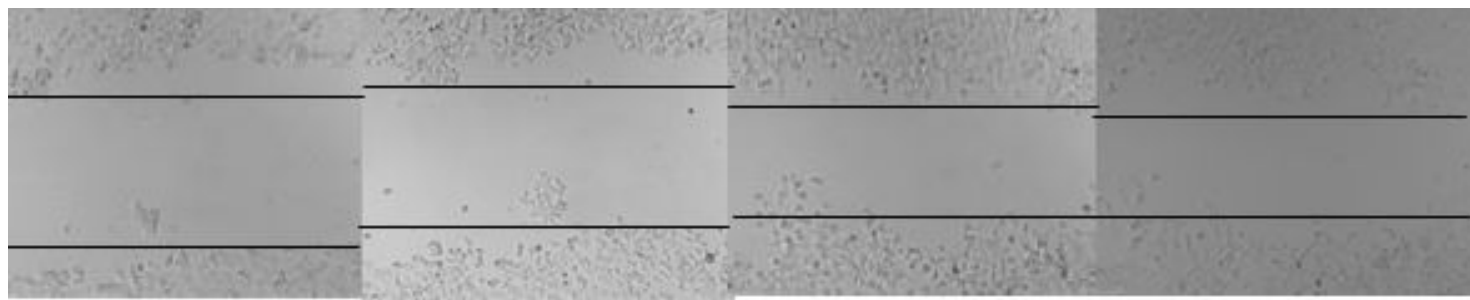

$99 \% \mathrm{MCF} 7+1 \% \mathrm{MSC}$

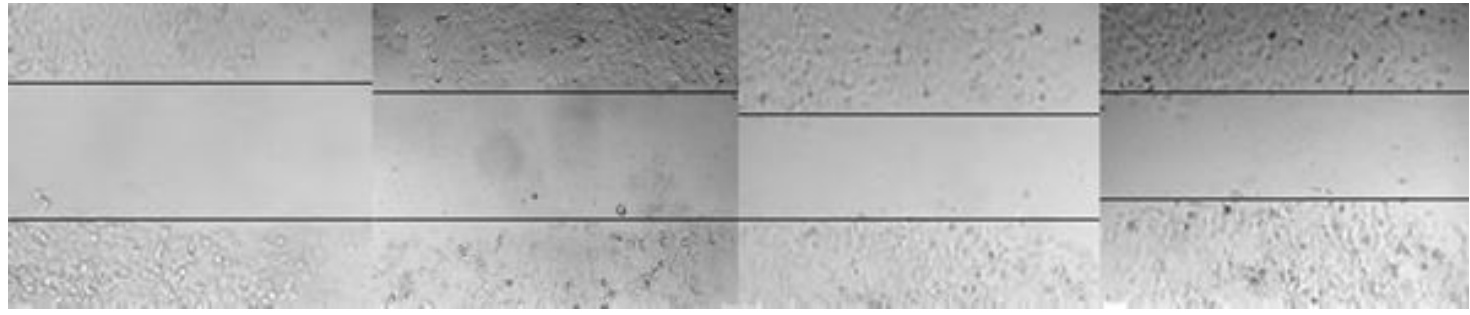

$90 \% \mathrm{MCF} 7+10 \% \mathrm{MSC}$

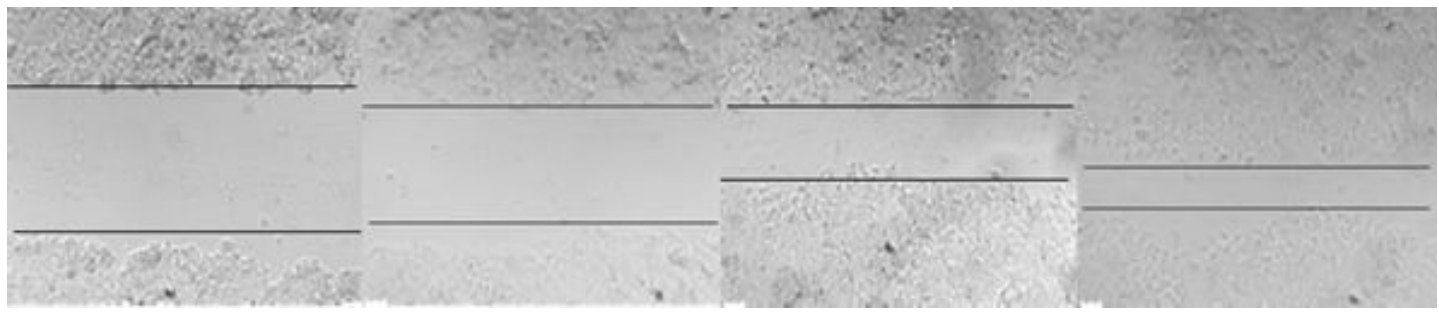

70\%MCF7+30\%MSC

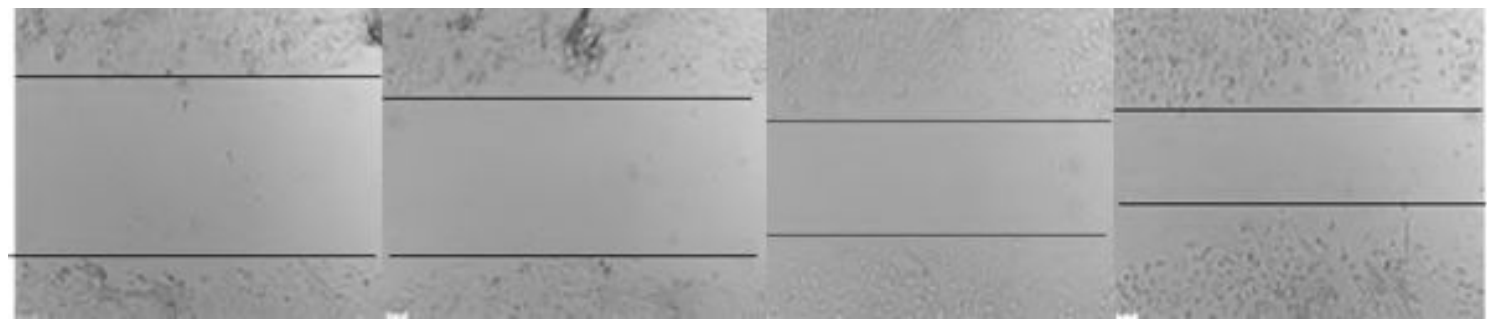

MCF7 em meio condicionado de MSC

Figura 4: Monocamada de células MCF-7 e coculturas nas proporções $99 \% \mathrm{MCF} 7+1 \% \mathrm{MSC}, 90 \%$ MCF7+10\%MSC e 70\% MCF7+30\%MSC, sob foco de microscópio de lentes invertidas de 10X. Avaliação a migração celular coletiva após "scratch"nos tempos de $0,6,18$ e 24 horas até o fechamento da ferida. 


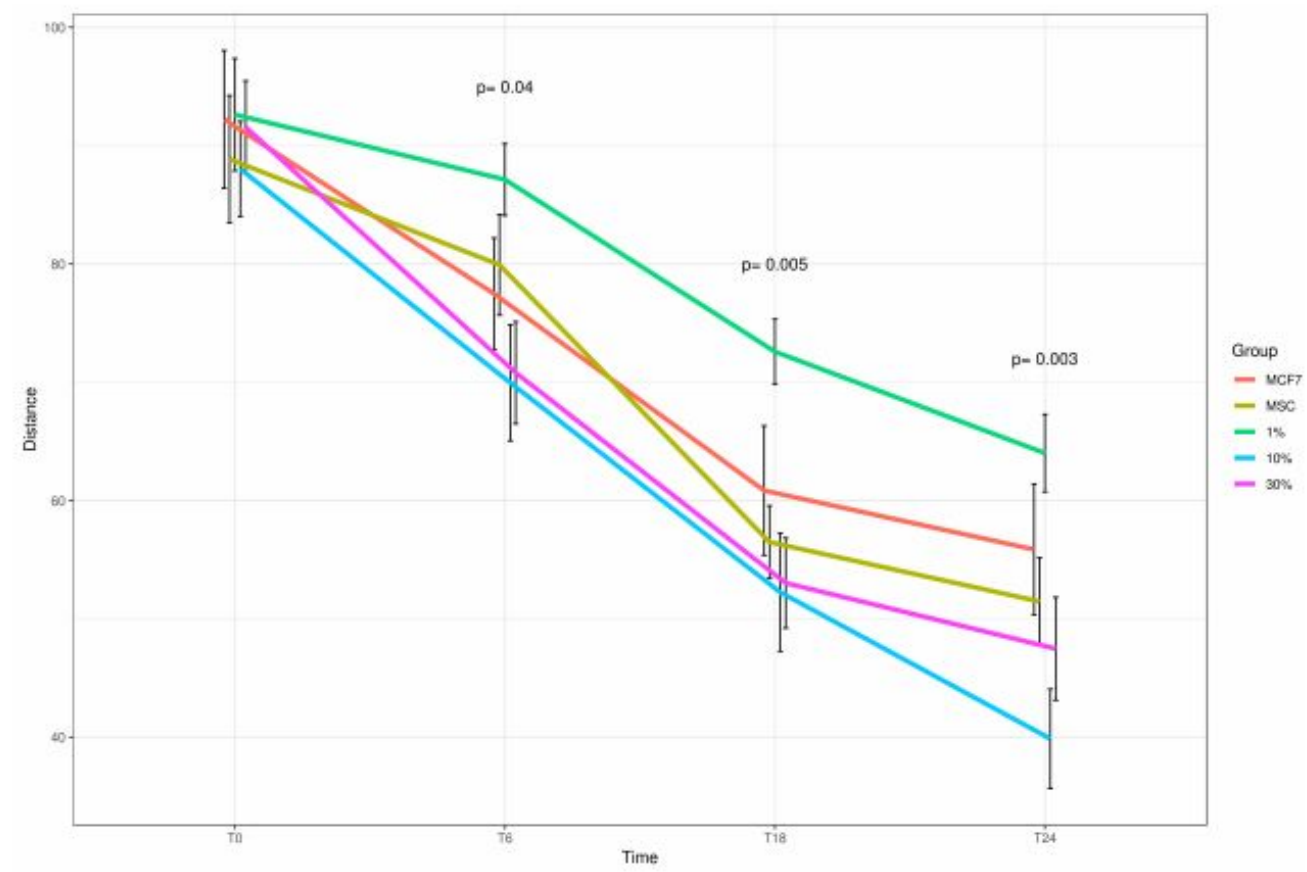

Gráfico 4: Monocamada de células MCF7 e cocultura nas proporções 99\%MCF7+1\%MSC, 90\% MCF $7+10 \%$ MSC e $70 \%$ MCF $7+30 \%$ MSC.

\subsection{Teste de invasão celular pela câmara de Boyden.}

Foi realizado ensaio de invasão celular em triplicatas e após o tempo de 24 horas, o ensaio foi interrompido e processado conforme protocolo adotado no método acima.

O controle positivo contendo células MCF-7 no superior e DMEM com soro bovino fetal (SBF) no inferior da câmara mostrou que células com esse estímulo invadiram a barreira de matrigel e a membrana com poros.

Os estímulos de meio de cocultura $1 \%$ e por meio condicionado de MSC foram efetivos para a invasão para a barreira de matrigel com a membrana com poros quando comparados ao controle MCF-7 com DMEM sem SBF, lembrando que todo o experimento foi realizado livre de SBF. Os valores de coculturas foram ajustados pelo número de células MCF-7 semeadas. 


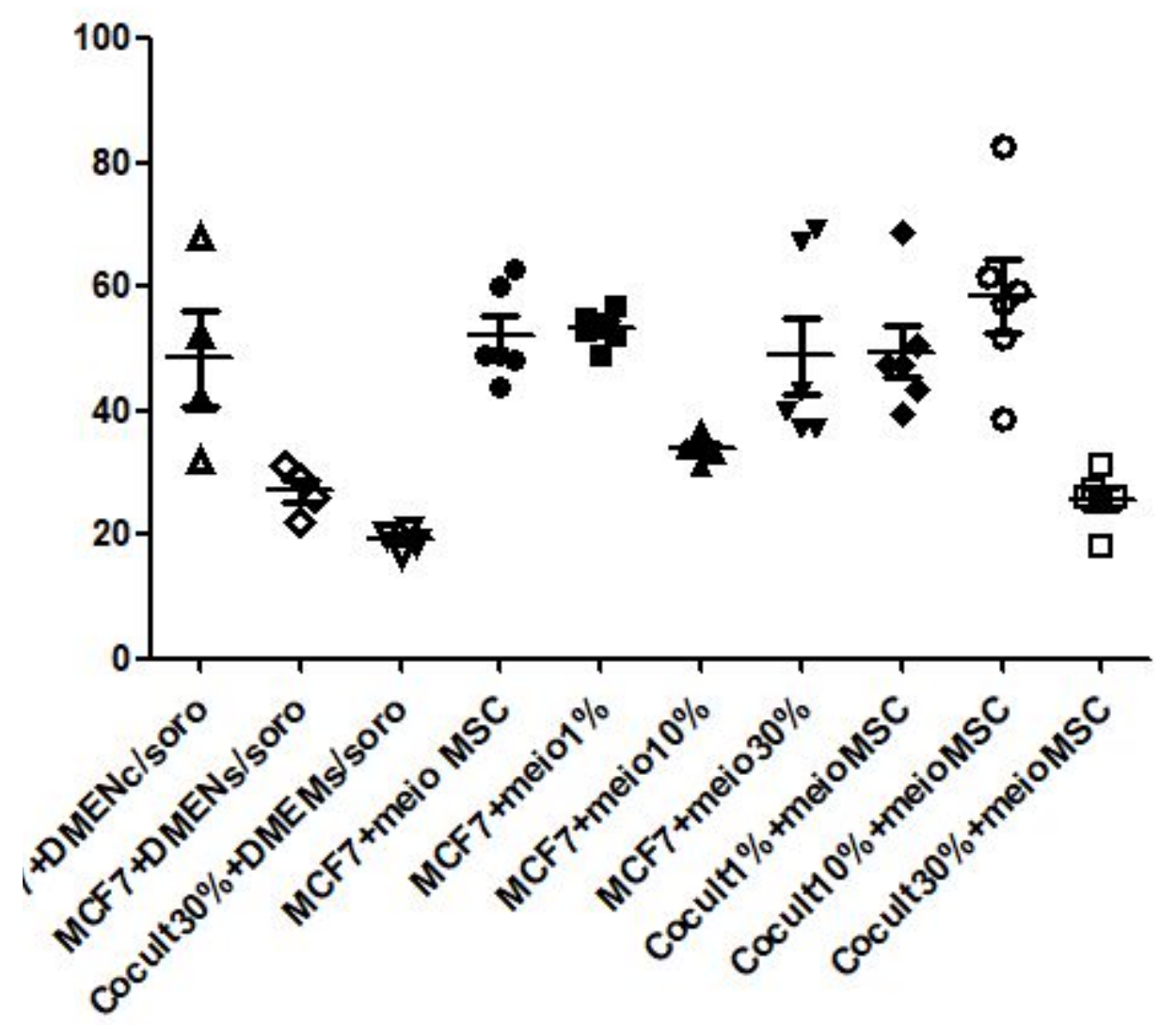

Gráfico 5: Invasão de células MCF-7 em câmara de boyden após 24 horas sob estímulo de meio condicionado de MSC, coculturas e com células e seu meio condicionado. No eixo X as condições quimioatraentes, no eixo Y número de células que passaram pela barreira oferecida pelo matrigel e pela membrana porosa dentro da câmara de boyden.

\subsection{Cultura em gel de colágeno 3D.}

Após gelificação do colágeno, foi padronizado mensuração da invasão celular no gel de colágeno e a morfologia celular nos dias 1, 3, 5 e 7 após início do experimento. As células MCF-7 utilizadas apresentavam GFP+. A foto foi realizada com lente FLUO para GFP+, DIC para imagem em cinza e a sobreposição das imagens foram retiradas utilizando Microscópio de Fluerescência Leica DMI600B. As imagens tiradas sob foco 8X utilizando Eletromicroscópio Leica MZFLIII com câmara DFC500. 


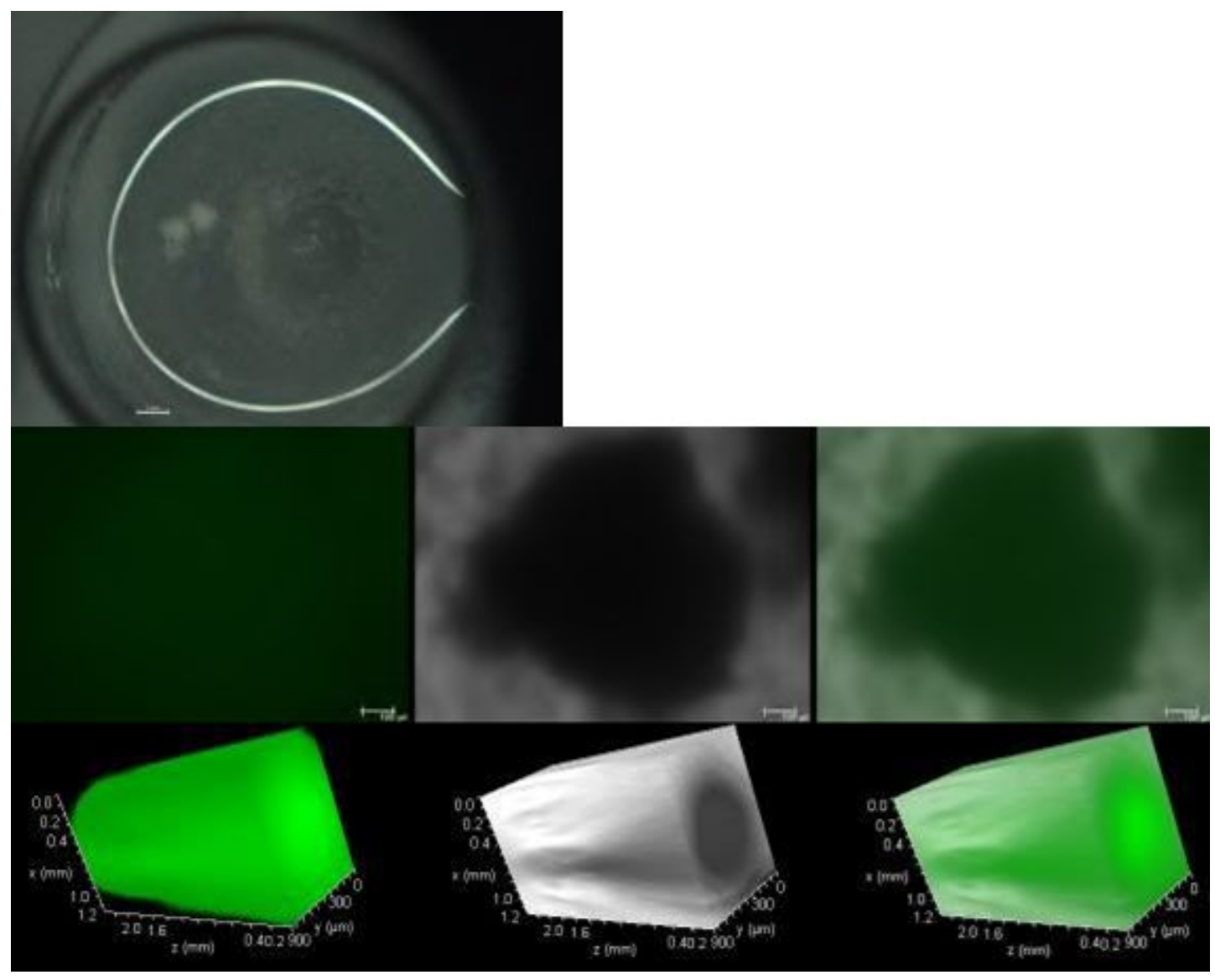

Figura 5: Cocultura $99 \% \mathrm{MCF} 7+1 \% \mathrm{MSC}$, sob foco $8 \mathrm{X}$ em lupa. Gel de colágeno 3D sob foco $10 \mathrm{X}$ e em corte $Z$.

As células em cocultura 99\%MCF7+1\%MSC adentraram no gel de colágeno 2,63 milímetros após 7 dias de análise em plano Z, conforme visto em figura 5. 


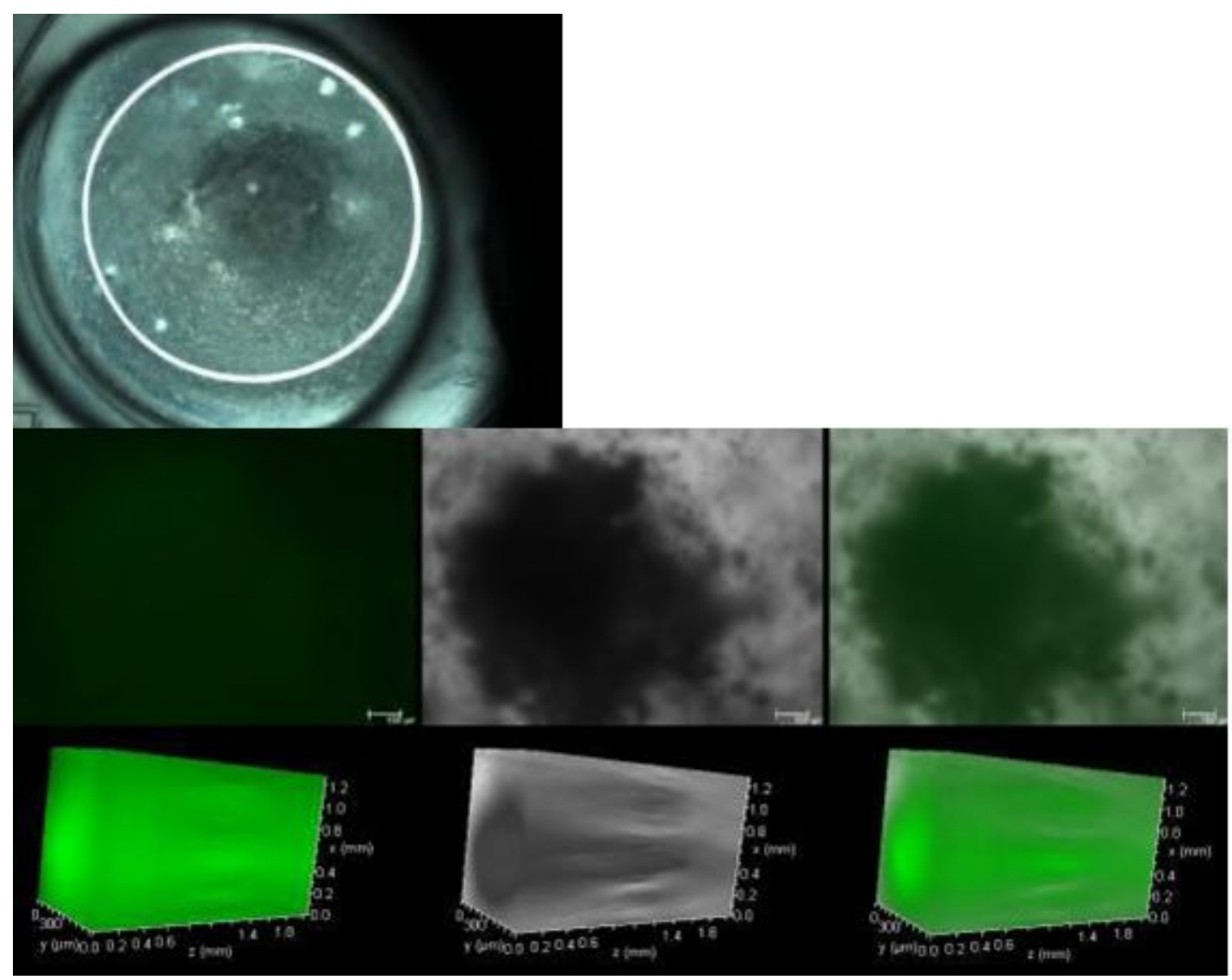

Figura 6: Cocultura $90 \%$ MCF7+10\%MSC sob foco $8 X$, em lupa. Gel de colágeno 3D sob foco $10 \mathrm{X}$ e em corte $Z$..

Células em cocultura 90\%MCF7+10\%MSC atingiram o gel de colágeno até a profundidade de 2,05 milímetros após 7 dias de análise em plano $Z$, conforme visto em figura 6. 


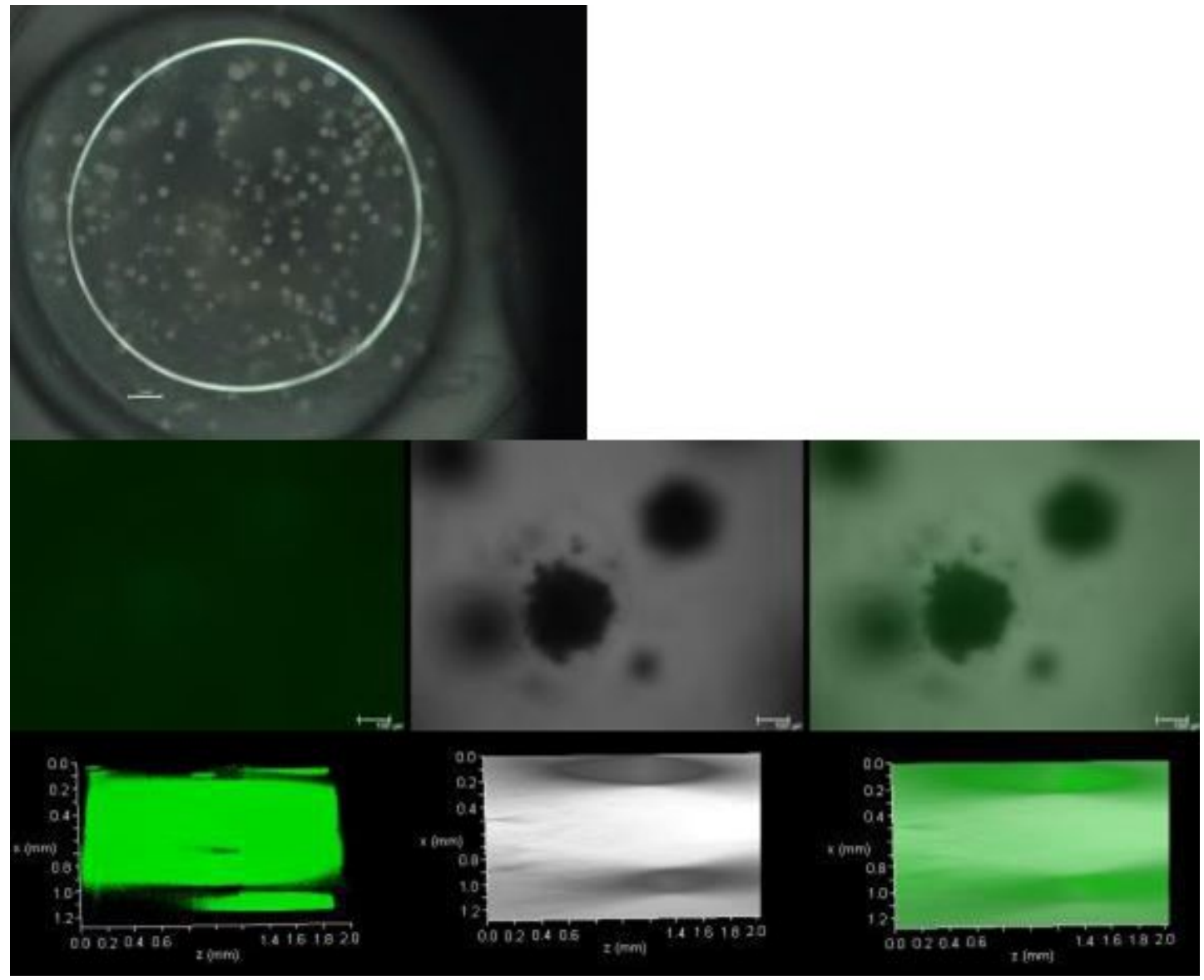

Figura 7: Cocultura 70\% MCF7+30\%MSC sob foco $8 \mathrm{X}$ em lupa. Gel de colágeno 3D sob foco $10 \mathrm{X}$ e em corte Z.

A cocultura de 70\%MCF7+30\%MSC invadiu 1,20 milímetros após 7 dias de análise em plano $Z$, atingindo, conforme visto em figura 7 . Nota-se que cocultura foi a única que apresentou perfil morfológico diferenciado das demais coculturas, mostrando células em menor tamanho e em diferentes planos na invasão pelo colágeno.

\subsection{Ensaio clonogênico.}

O ensaio foi realizado em triplicatas, finalizado após 10 dias, momento que o crescimento das colônias apresentavam tamanho adequado, com diferenciação entre as colônias e principalmente, evitando que o crescimento das colônias excedesse e permitisse a distinção entre colônias. 
Comparando as diferentes culturas, diante do tempo de cultivo para formação das colônias, verificou-se que existem diferenças entre o crescimento nas diferentes populações das colônias, tendo estas atividades proliferativas distintas.

Sobre o número de colônias formadas, foi verificado diferença entre os crescimentos e no tamanho das colônias. Pode-se notar que culturas que tinham em sua mistura mais células MSC apresentaram menor tamanho, assemelhando-se às células MSC utilizadas como controle no experimento.

Este comportamento de menor tamanho de colônias se justifica com a hipótese deste estudo, que trabalha a perspectiva da interação de linhagens de células com perfil epitelial e sua mudança biológica frente ao estímulo com células MSC. As colônias estão representadas na figura 8 , tumores com perfil epitelial, como o apresentado por MCF-7 ao estarem em estímulo a células MSC e seu substrato, venham a se comportar diferentemente, apresentando agora com caráter mesenquimal, após o estímulo com $30 \%$ de células mesenquimais, as colônias de MCF-7 apresentaram número e dimensões significativamente distintas de células MCF-7 cultivadas em 2D sem nenhum estímulo com probabilidade de significância $<0.05$. 


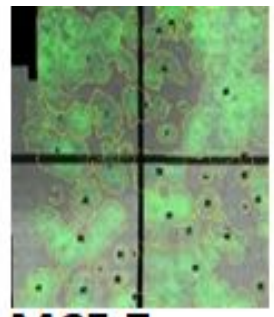

MCF-7
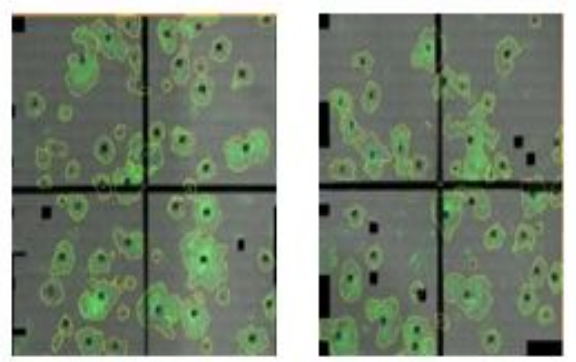

$90 \%$ MCF-7 + $10 \%$ MSC
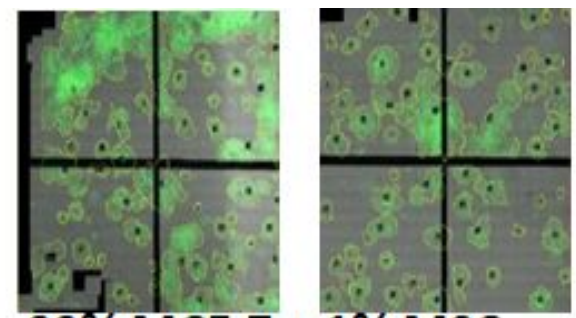

$99 \%$ MCF-7 + $1 \%$ MSC
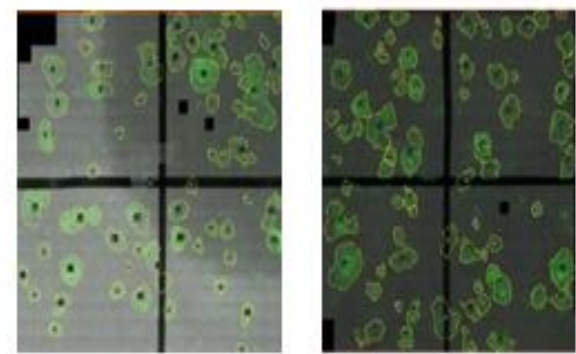

$70 \%$ MCF-7 + 30\% MSC

Figura 8: Imagem representativa das colônias formadas pelo ensaio clonogênico após 10 dias de cultivo fotos tiradas em microscópio confocal, realizado "stitching" das imagens.

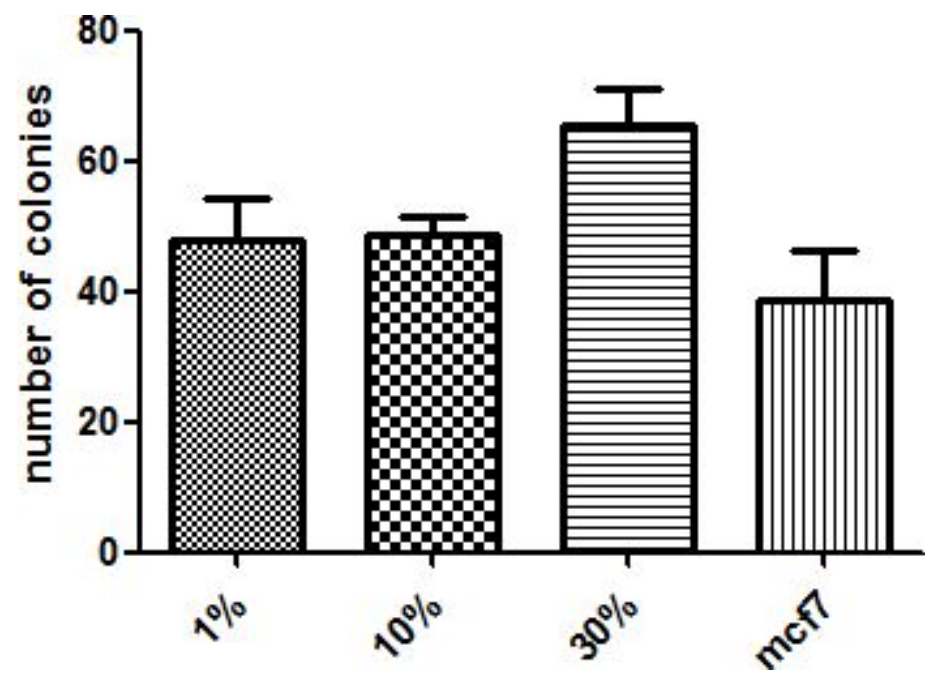

Gráfico 6: Número de colônias formadas com o ensaio clonogênico. A capacidade de formação de colônias com o estímulo de $30 \%$ de células mesenquimais na cultura de MCF-7 possibilitou aumento no tamanho do número de colônias e diminuição do tamanho das colônias.

\subsection{Imunocitoquímica e imunofluorescência.}

Foram realizados testes com marcação para $\beta$-catenina, e-caderina, n-caderina e vimentina. Células MCF-7 GFP+ foram cocultivadas com MSC e discriminadas nas marcações por expressarem 
GFP+. Para visualização do núcleo celular, as células foram montadas com ProLong (Thermo Fisher Scientifc) conjugado com DAPI para detecção do sinal nuclear. Os sinais de fluorescência foram observados e fotografados com o microscópio multifoton Leica SP5 e análise foi realizada utilizando o programa de imagens Fiji. Para análise de expressão, células GFP+ foram selecionadas e traçado reta sagital à célula, compreendendo as membranas, citoplasma e núcleo. A partir do sinal produzido pelo anticorpo foi realizado análise de intensidade de sinal.
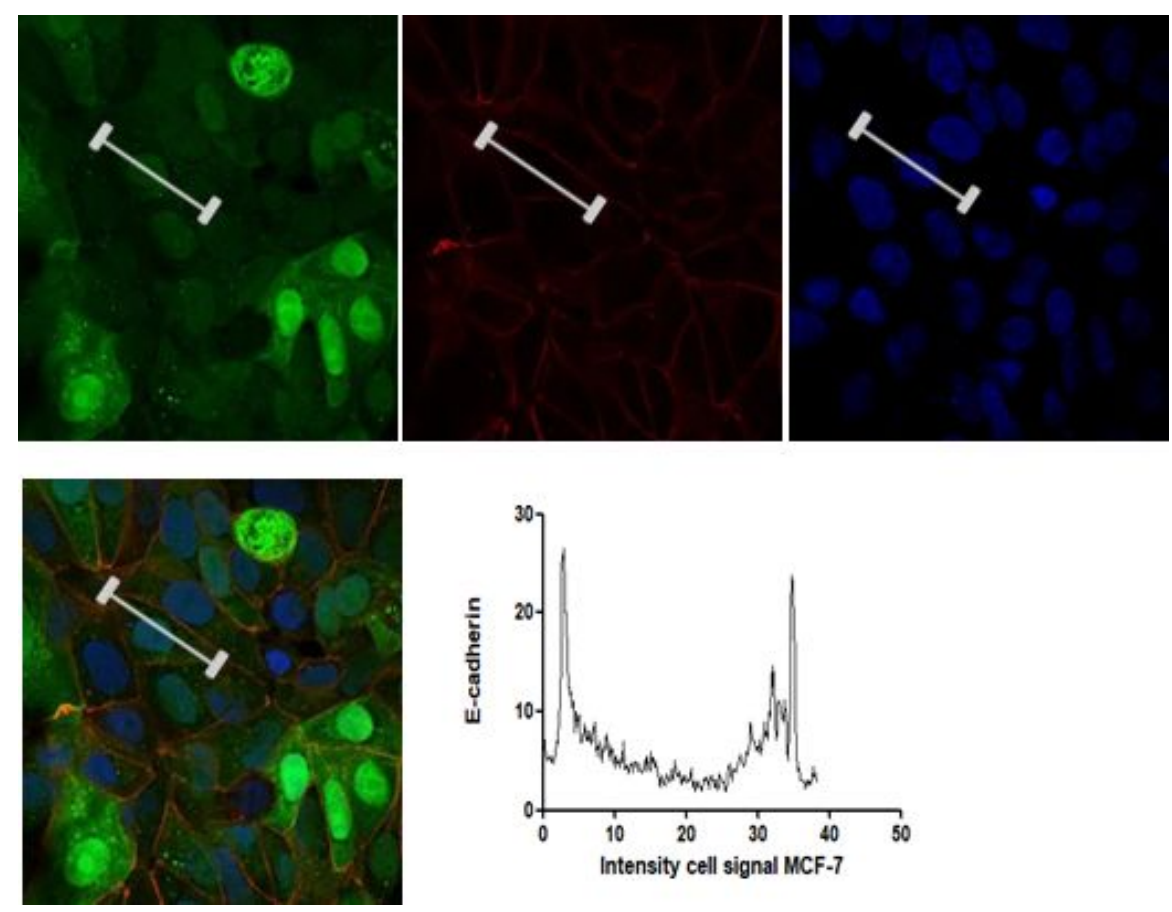

Figura 9: células MCF-7 expressando GFP e marcadas E-caderina, DAPI com merge de três canais, gráfico da expressão da molécula E-caderina. 

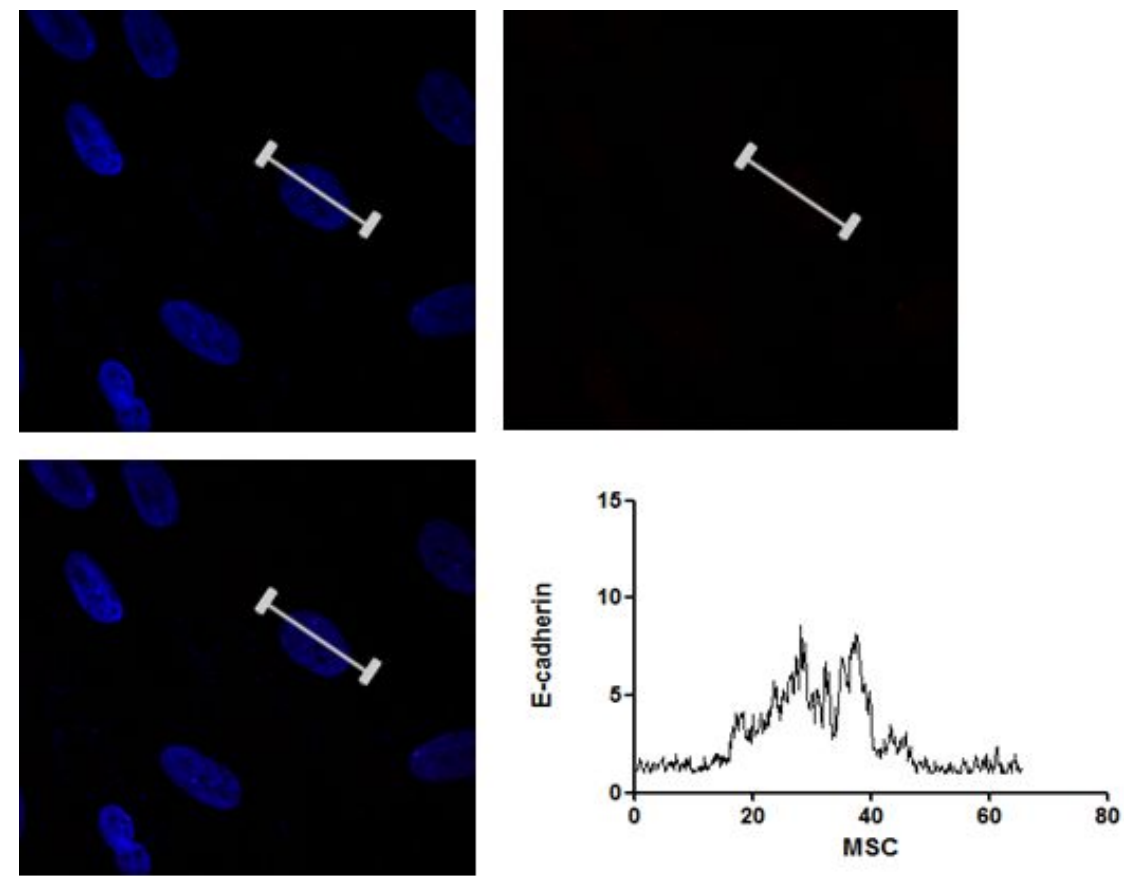

Figura 10: células MSC marcadas E-caderina, DAPI com merge de três canais, gráfico da expressão da molécula E-caderina.
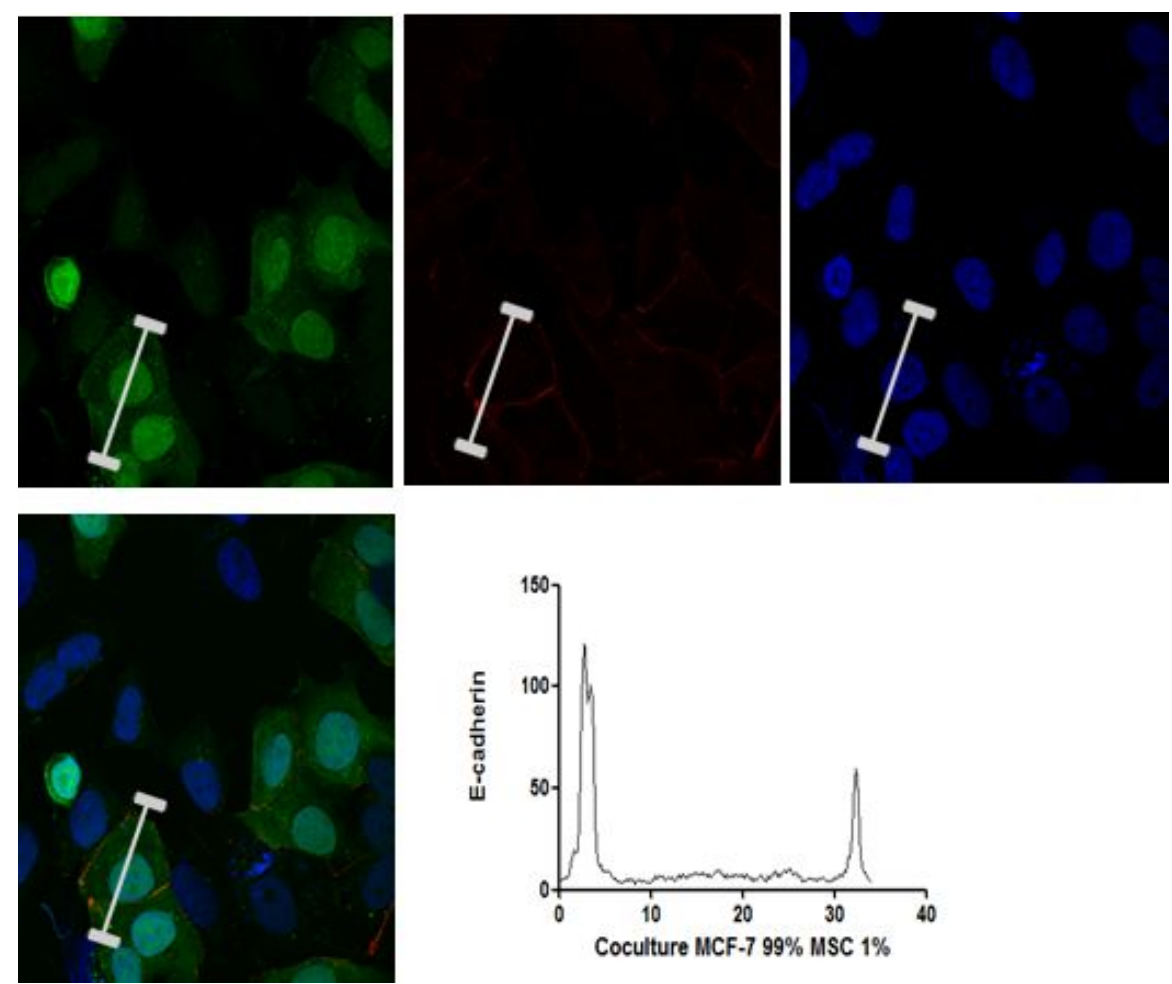

Figura 11: cocultura 99\%MCF-7 1\%MSC expressando GFP e marcadas E-caderina, DAPI com merge de três canais, gráfico da expressão da molécula E-caderina. 

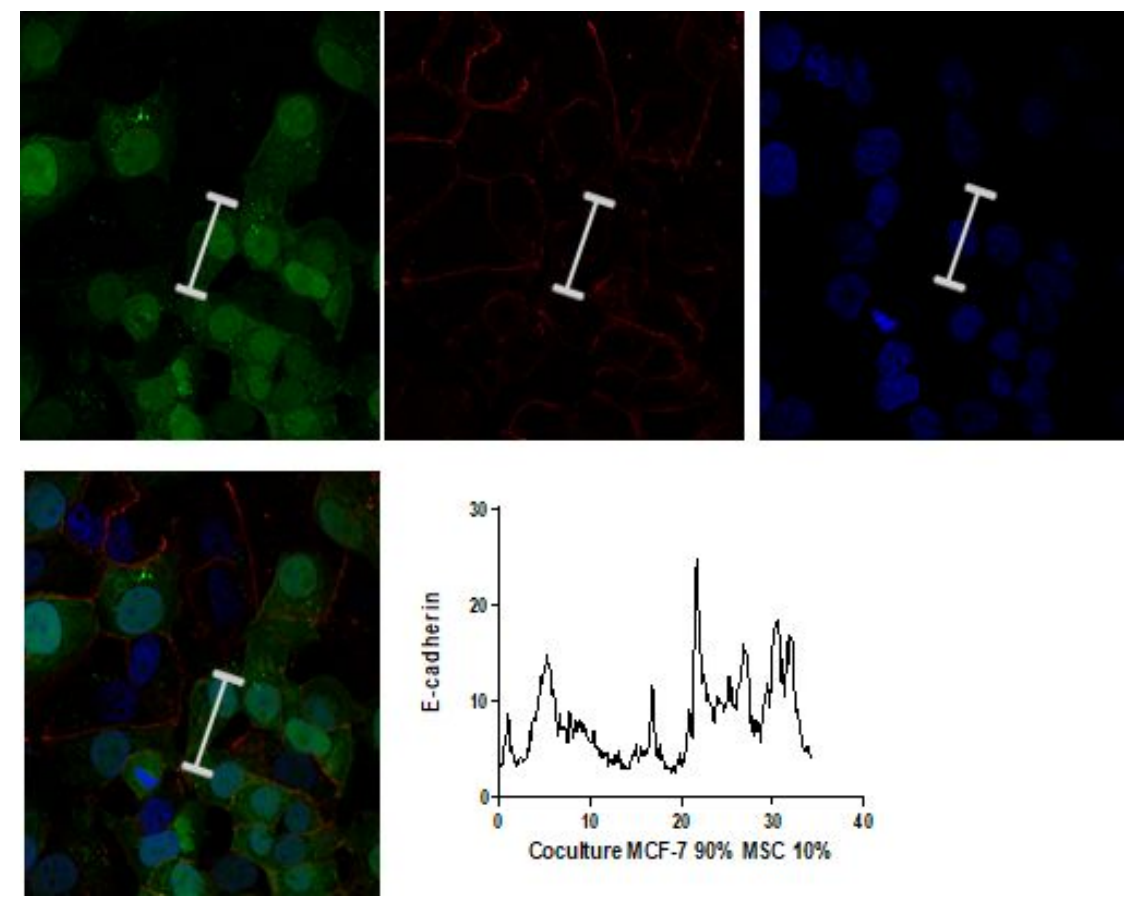

Figura 12: cocultura 90\%MCF-7 10\%MSC expressando GFP e marcadas E-caderina, DAPI com merge de três canais, gráfico da expressão da molécula E-caderina.
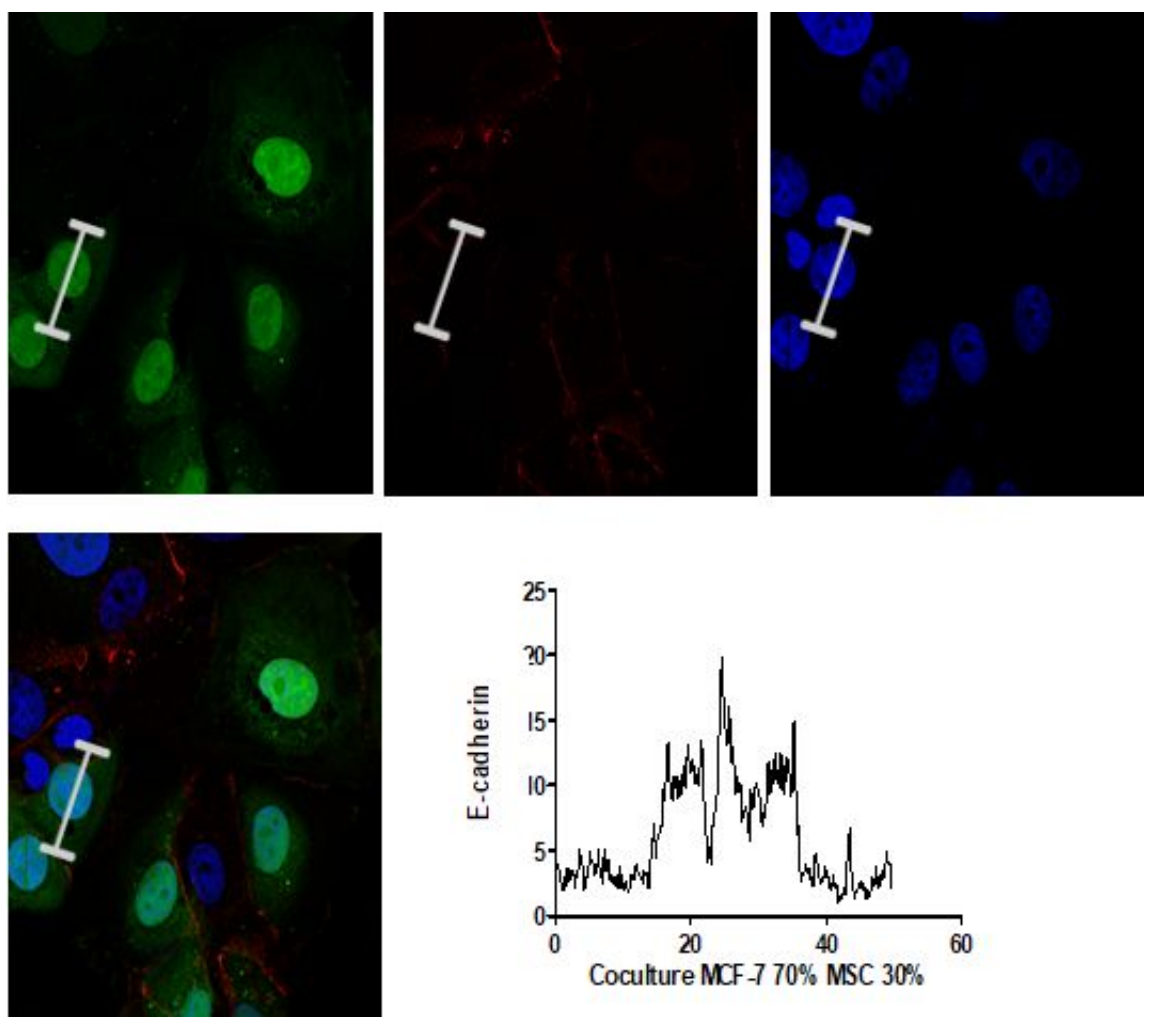

Figura 13: cocultura 70\%MCF-7 30\%MSC expressando GFP e marcadas E-caderina, DAPI com merge de três canais, gráfico da expressão da molécula E-caderina. 

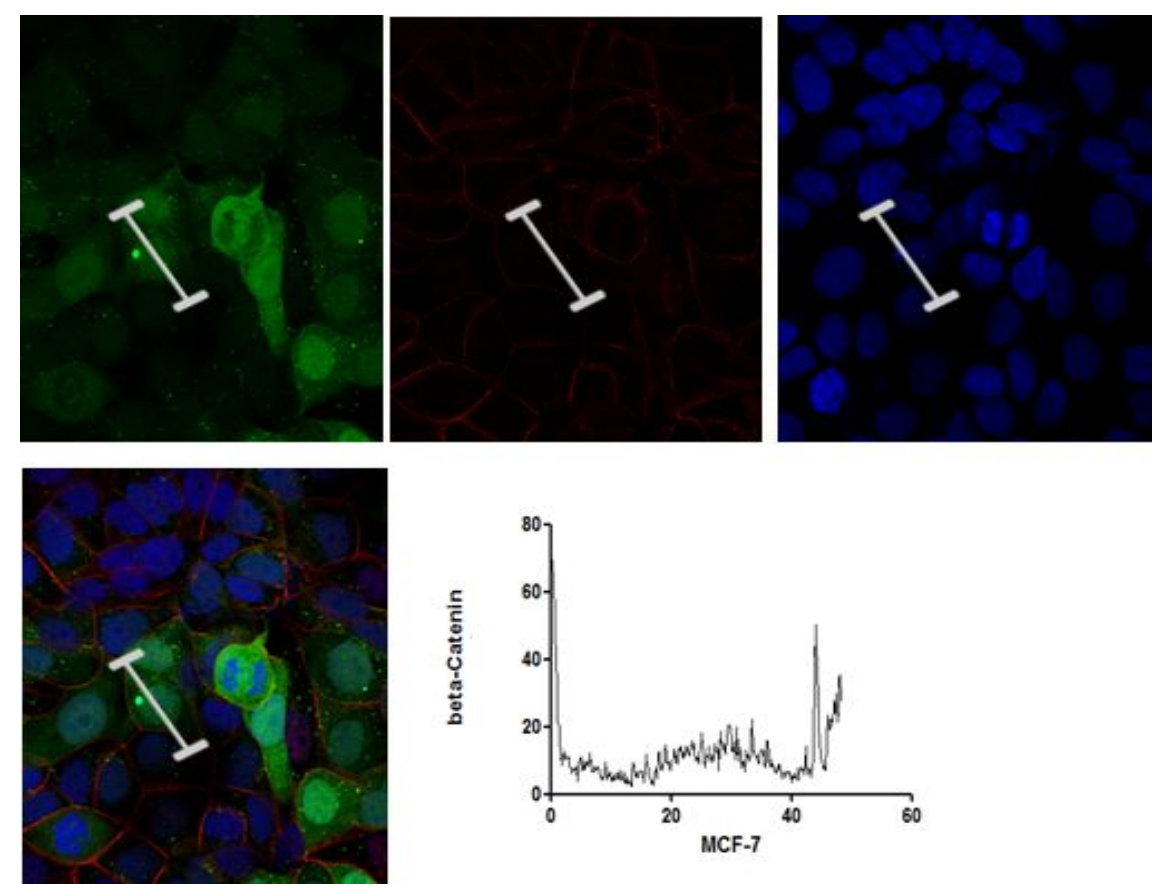

Figura 14: cultura MCF-7 marcadas em sequencia GFP+, $\beta$-catenina, DAPI, merge de três canais, gráfico da expressão da molécula E-caderina.
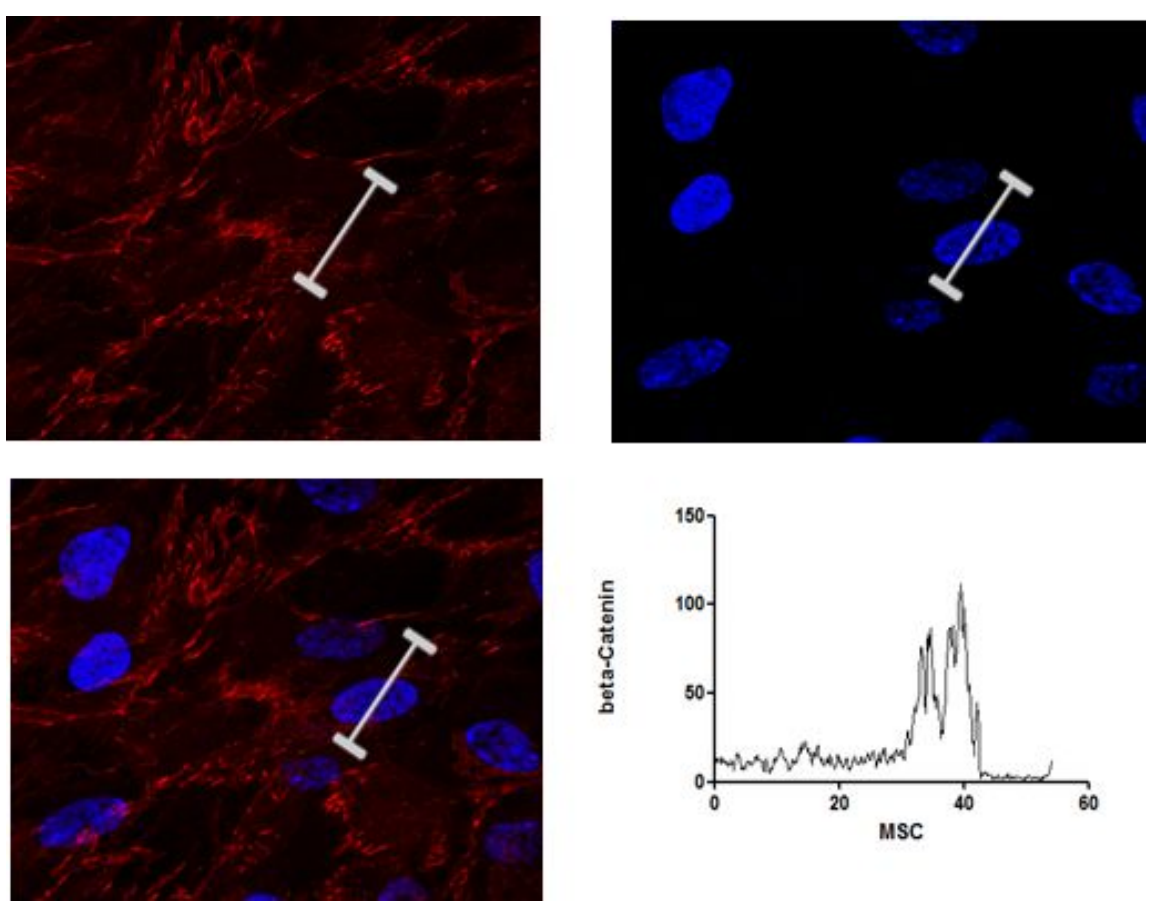

Figura 15: células MSC marcadas em sequencia $\beta$-catenina, DAPI, merge de dois canais, gráfico da expressão da molécula $\beta$-catenina. 

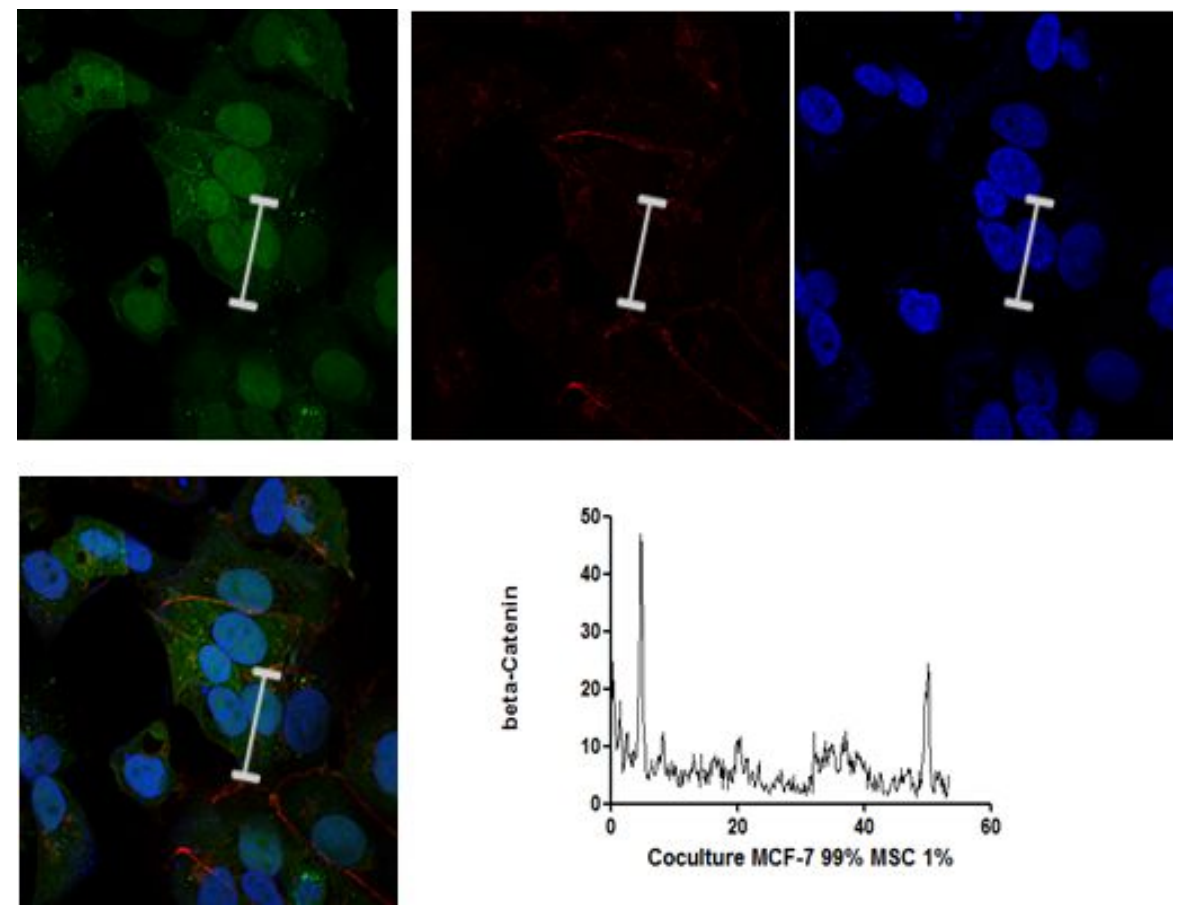

Figura 16: cocultura 99\%MCF7 1\%MSC marcadas em sequencia GFP+ , $\beta$-catenina, DAPI, merge de três canais, gráfico da expressão da molécula $\beta$-catenina.
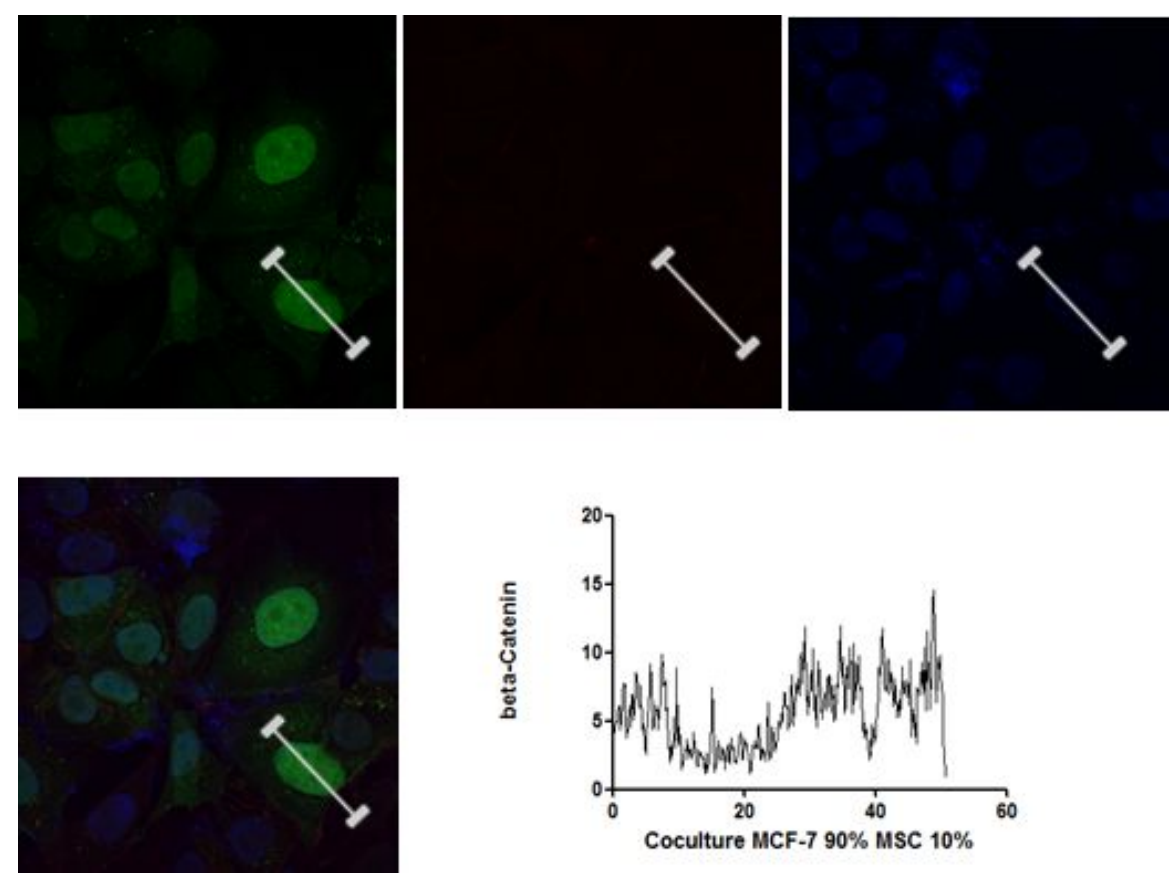

Figura 17: cocultura 90\%MCF7 10\%MSC marcadas em sequencia GFP+ , $\beta$-catenina, DAPI, merge de três canais, gráfico da expressão da molécula $\beta$-catenina. 

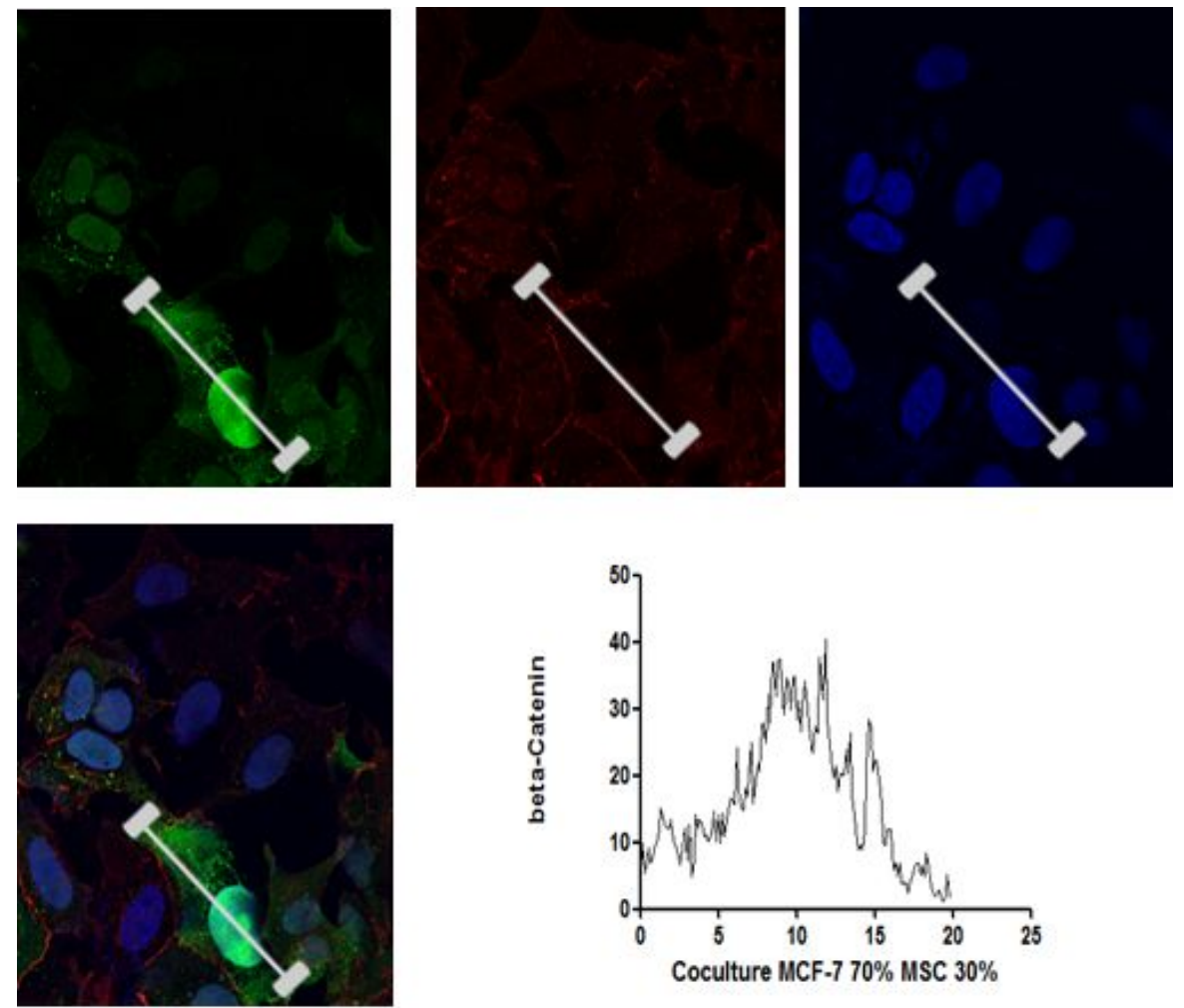

Figura 18:cocultura 70\%MCF7 $30 \%$ MSC marcadas em sequencia GFP+ $\beta$-catenina, DAPI, merge de três canais, gráfico da expressão da molécula $\beta$-catenina.
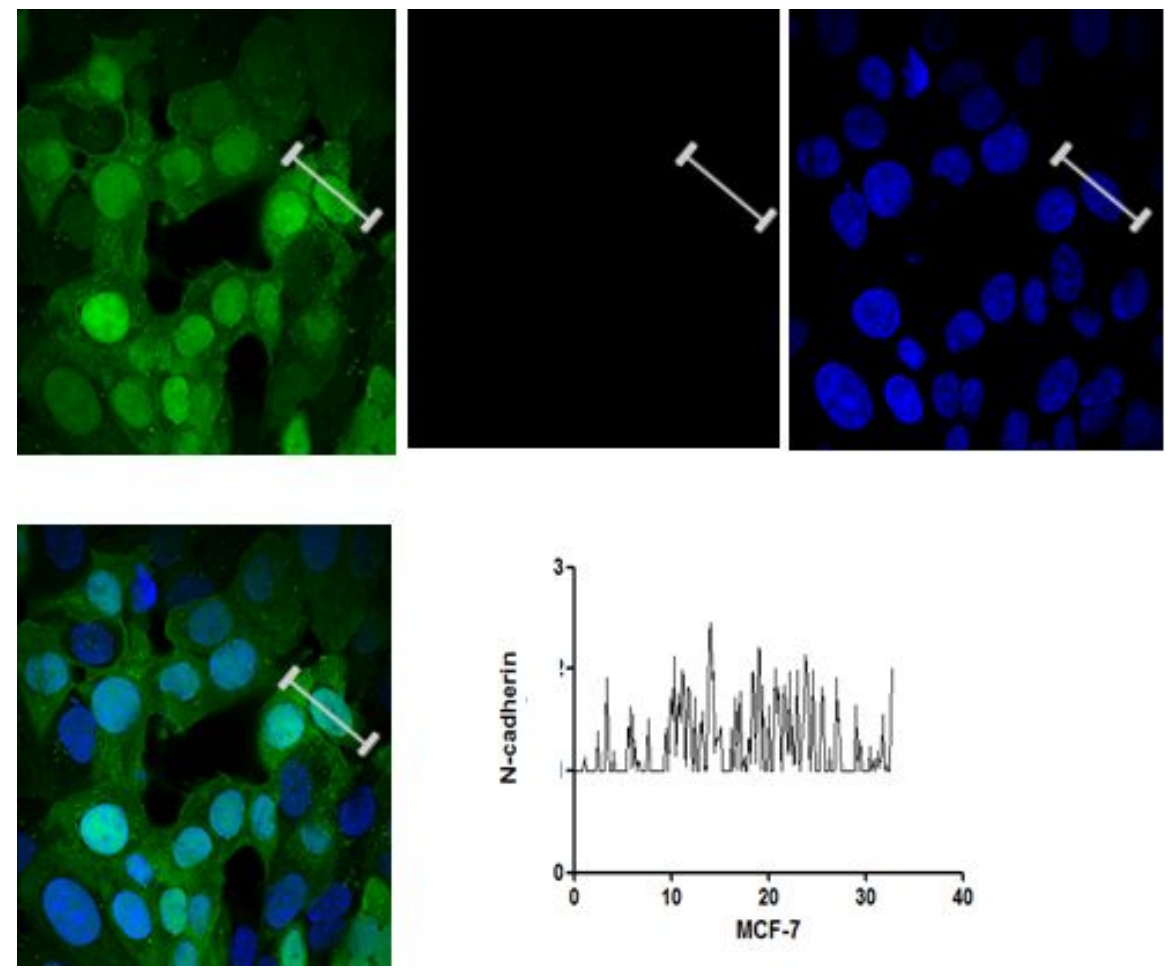

Figura 19:cultura MCF7 marcadas em sequencia GFP+,n-caderina, DAPI, merge de três canais, gráfico da expressão da molécula n-caderina. 

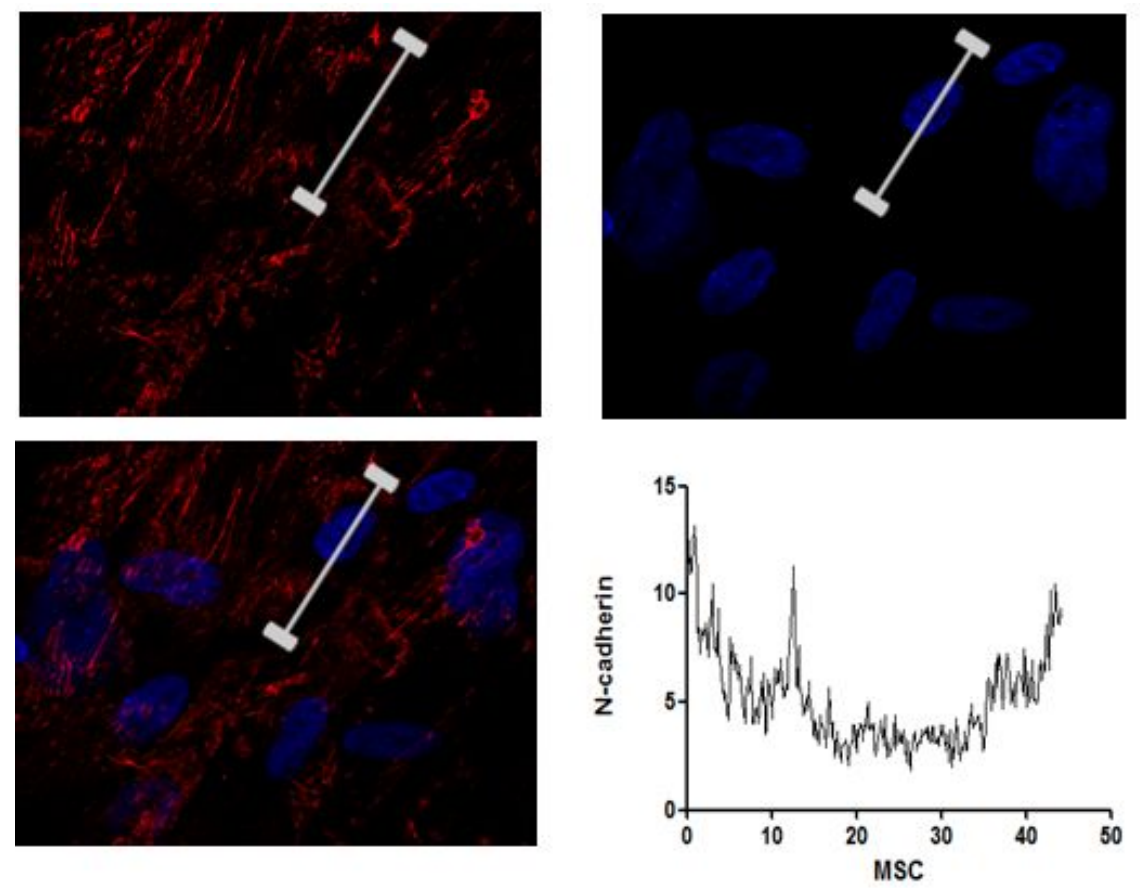

Figura 20:cultura MSC marcadas em sequencia n-caderina, DAPI, merge de dois canais, gráfico da expressão da molécula n-caderina.
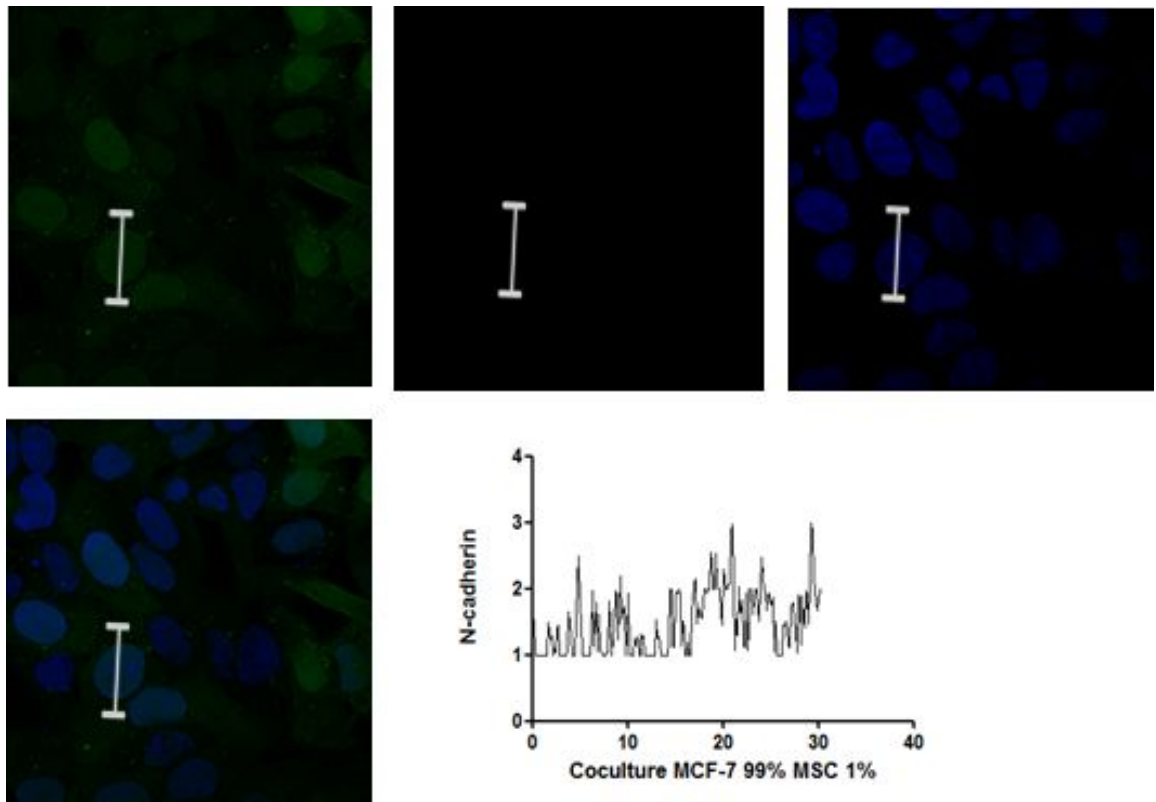

Figura 21:cocultura 99\% MCF7 1\%MSC marcadas em sequencia GFP+,n-caderina, DAPI, merge de três canais, gráfico da expressão da molécula n-caderina. 

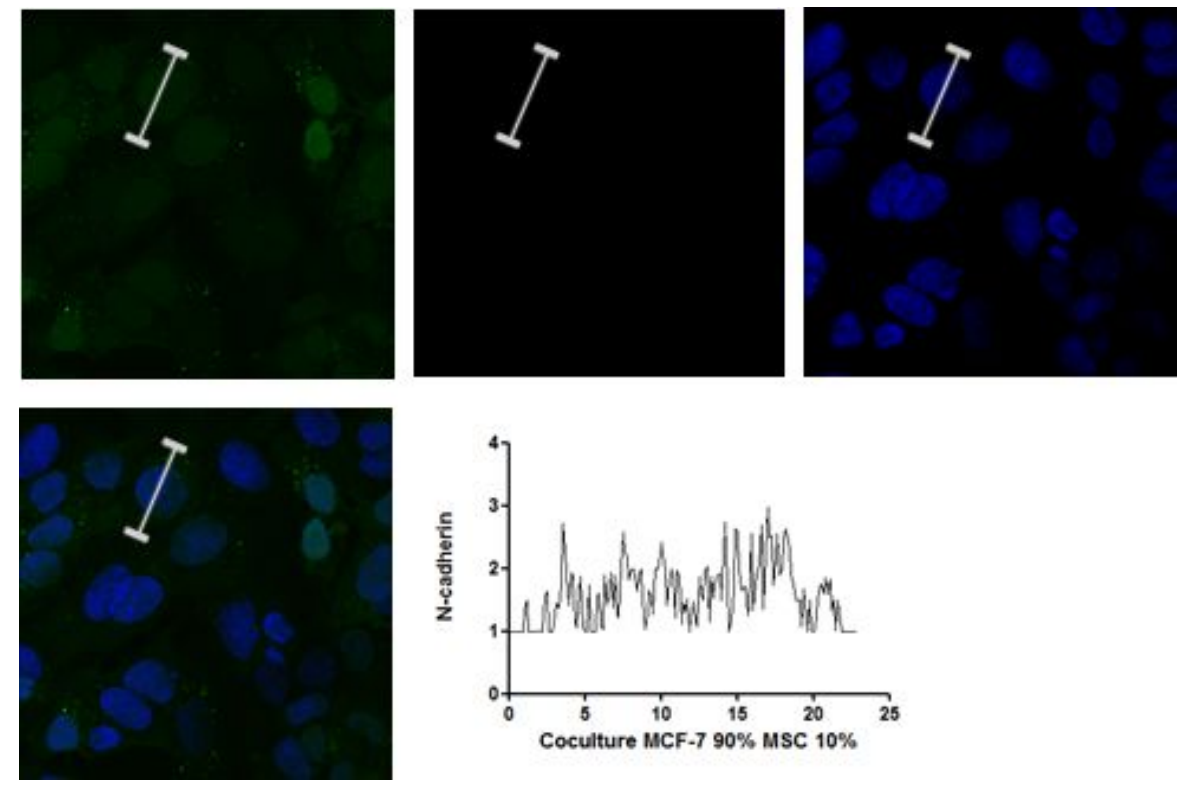

Figura 22: cocultura 90\% MCF7 10\%MSC marcadas em sequencia GFP+,n-caderina, DAPI, merge de três canais, gráfico da expressão da molécula n-caderina.
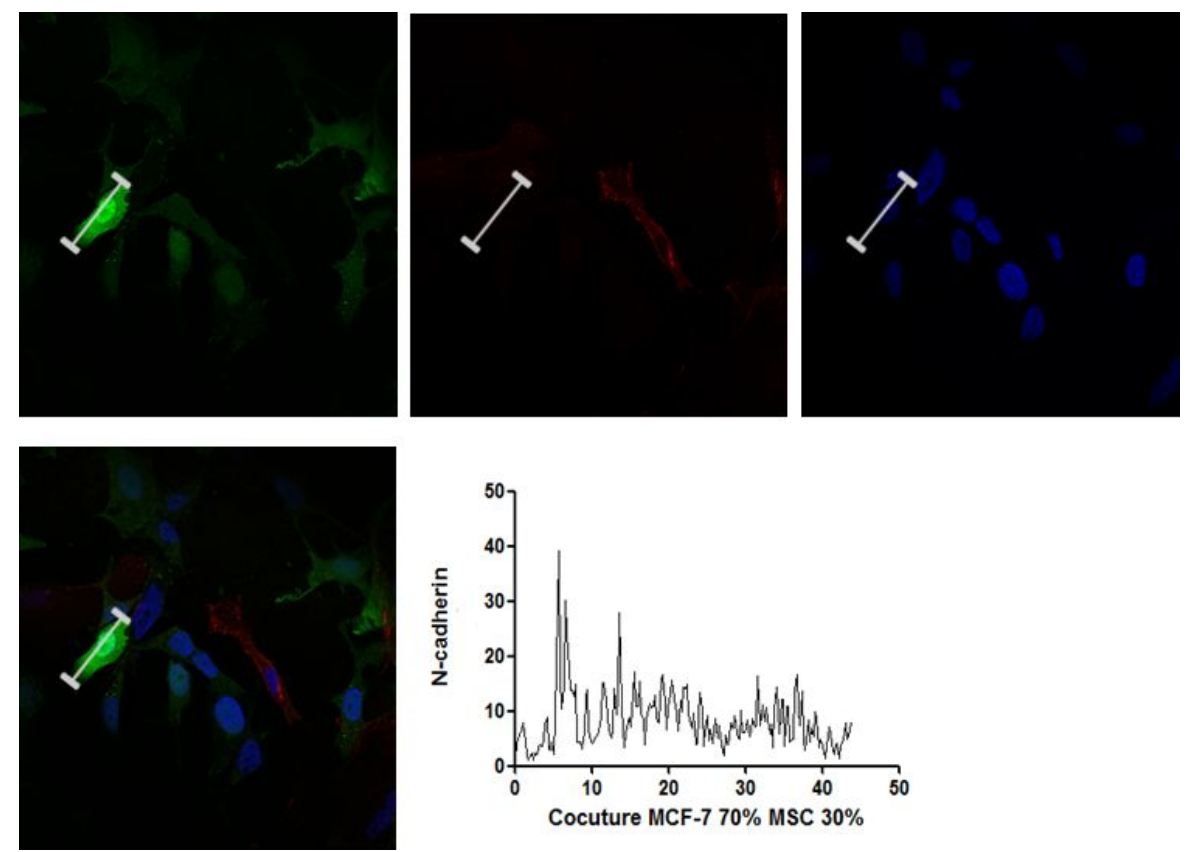

Figura 23: cocultura 70\% MCF7 30\%MSC marcadas em sequencia GFP+,n-caderina, DAPI, merge de três canais, ggráfico da expressão da molécula n-caderina.

\subsection{Tumorigenicidade em modelo animal.}

No primeiro ensaio foi implantado células MCF-7 e em cocultura 90\%MCF7+10\%MSC em 8 camundongos SWISS nude fêmeas a fim de testar a concentração celular a injetar no animal. Neste modelo mostrou não ser viável, pois os animais não desenvolveram crescimento tumoral 
após 12 semanas. No segundo ensaio foram utilizados 9 camundongos NOD/SCID fêmeas com 14 semanas de idade para avaliação tumorigenicidade, como forma de teste piloto. Neste teste 3 grupos com 3 animais por grupo para avaliação crescimento e disseminação tumoral foi

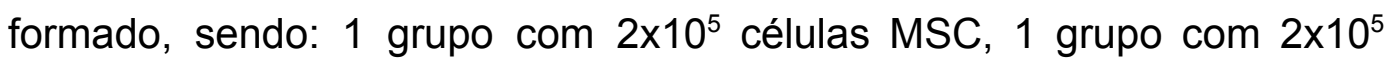
células MSC e fragmento de tumor, 1 grupo com fragmento de tumor. Dois animais, um do grupo com células MSC e um do grupo com fragmento de tumor vieram a óbito após implante de tumor e células.

Os animais foram monitorados por oito semanas até a observação por medição e palpação para formação do tumor. Após o período de oito semanas, os demais animais foram sacrificados e seus tumores congelados. Este teste piloto foi importante para delimitação da melhor cobaia a ser utilizada no protocolo de tumorigenicidade em modelo animal.

Como terceiro teste foi utilizado camundongos NOD/SCID fêmeas divididos em 2 grupos com 8 animais por grupo para avaliação crescimento e disseminação tumoral, sendo: 1 grupo com $1 \times 10^{6}$ células MCF-7, 1 grupo com $1 \times 10^{6}$ de células em cocultura $90 \% \mathrm{MCF} 7+10 \% \mathrm{MSC}$. Dois animais do grupo MCF-7 vieram a óbito na oitava e nona semana após injeção e um animal do grupo cocultura veio a óbito na décima semana após injeção com células.

Os animais foram sacrificados em sua décima oitava semana de cuidados, devido a idade avançada dos animais (um ano e três meses de vida). Todos os animais do grupo MCF-7 apresentaram tumor em parede abdominal e em glândula mamária e 4 animais do grupo cocultura apresentaram tumor em parede abdominal e em glândula mamária. Foram recolhidos os tumores, glândulas mamárias e pulmão, incluídos em parafina para análise histológica.

Observou-se crescimento tumoral localizado nos animais injetados somente o pool de células MCF-7. O possível observar o crescimento tumoral disseminado na parede abdominal, mama e linfonodos nos animais injetados com a cocultura $90 \% \mathrm{MCF} 7+10 \% \mathrm{MSC}$, visto na figura 
24. A análise estatística não apresentou diferença significativa possivelmente pelos grupos de animais serem pequenos para o ensaio, apenas 6-7 animais, conforme gráfico 5 .
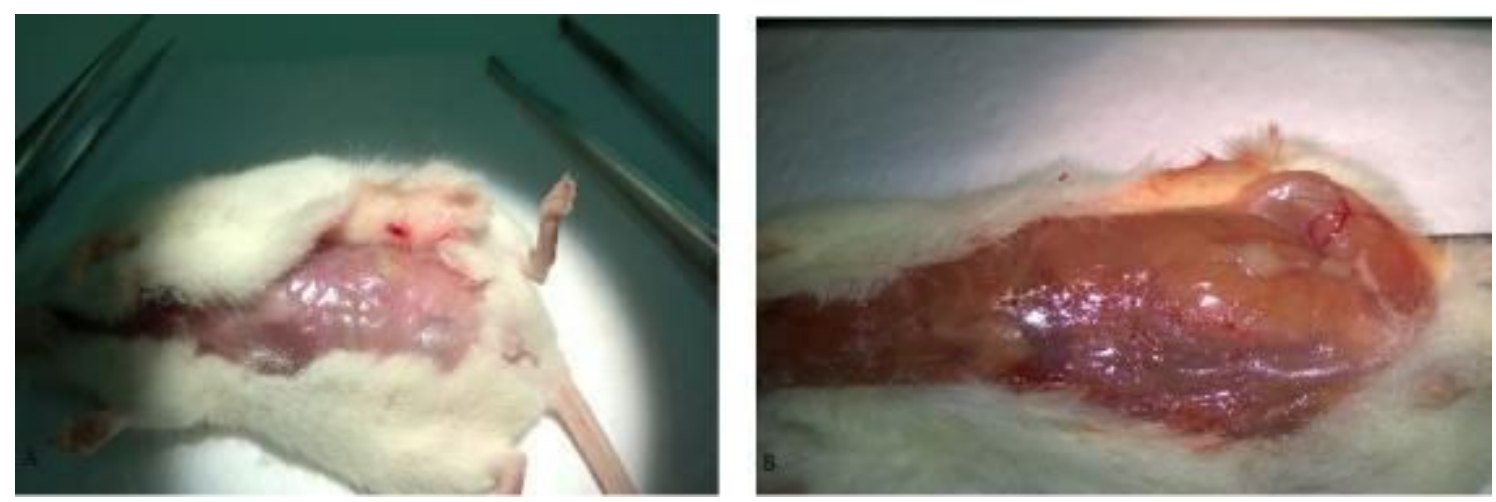

Figura 24: Camundongo com tumor inserido bilateralmente na quarta mama da fat pad; A: tumor localizado em parede abdominal com inserção de células MCF7; B: tumor com disseminação em parede abdominal, mama e linfonodo com inserção de cocultura 90\%MCF7+10\%MSC.

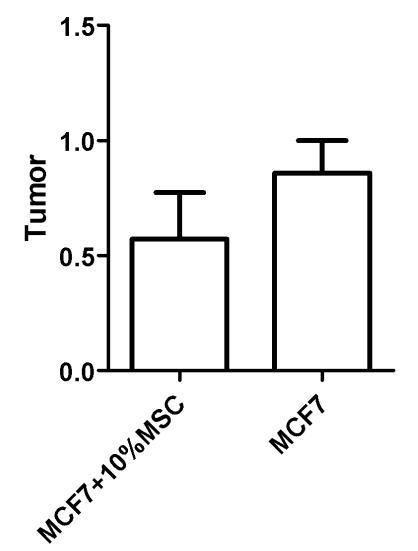

Gráfico 7: Número de tumores formados em animais NOD/SCID gamma no grupo MCF-7 e no grupo cocultura 90\% MCF7+10\%MSC com diferença estatística não significante $p=0.174$.

\subsection{Imunohistoquímica.}

Foi realizada imunomarcação para os tumores obtidos dos animais MCF-7 e a cocultura MCF-7 +1\%MSC para a marcação com e-caderina, vimentina e b-catenina. Foi utilizado o teste chi-square para a análise estatística. A comparação entre os grupos MCF-7 e cocultura mostrou que existe uma tendência para diminuição da expressão de e-caderina $(p=0.133614)$ e aumento da expressão de vimentina $(p=0.67329)$ e de b-catenina $(p=0.57075)$. 

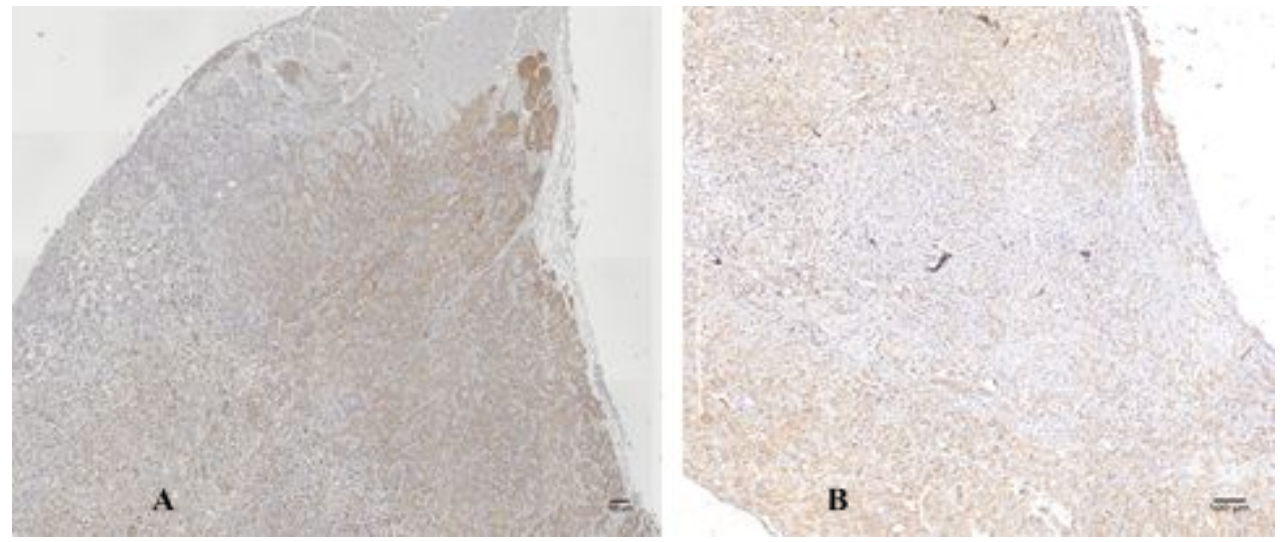

Figura 25: Reação de imunhistoquímica utilizando o anticorpo anti- e-caderina. A: tumor de animal do grupo MCF7, com marcação forte e focal; B: tumor de animal do grupo no grupo cocultura $90 \%$ MCF7+10\%MSC, com marcação fraco e difuso.
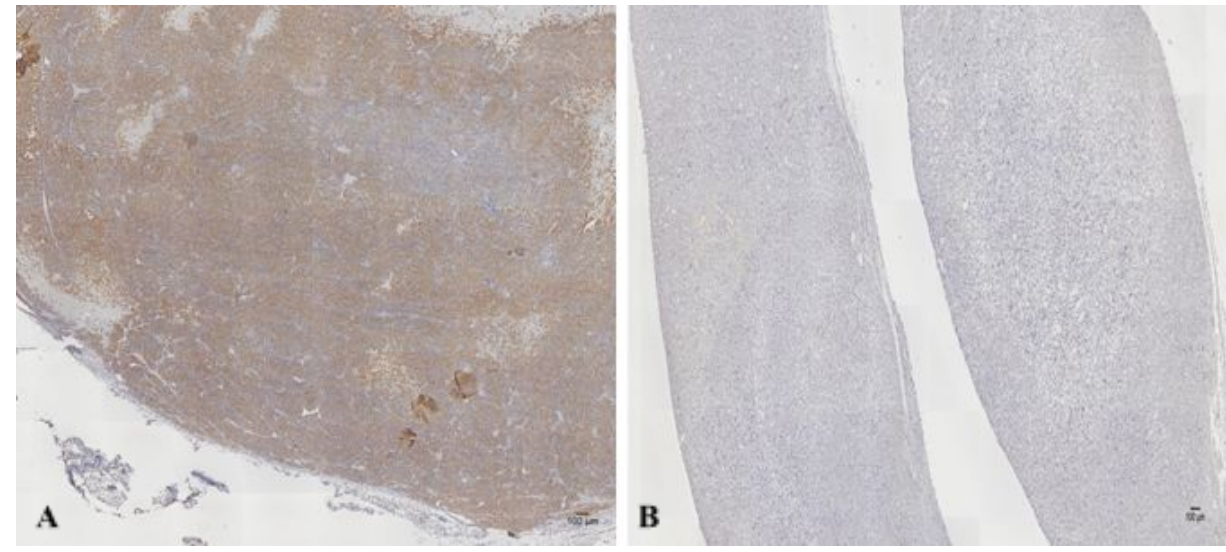

Figura 26: Reação de imunhistoquímica utilizando o anticorpo anti-vimentina. A: tumor de animal do grupo MCF7, com marcação negativa; B: tumor de animal do grupo no grupo cocultura $90 \%$ MCF7+10\%MSC, com marcação fraco e focal.

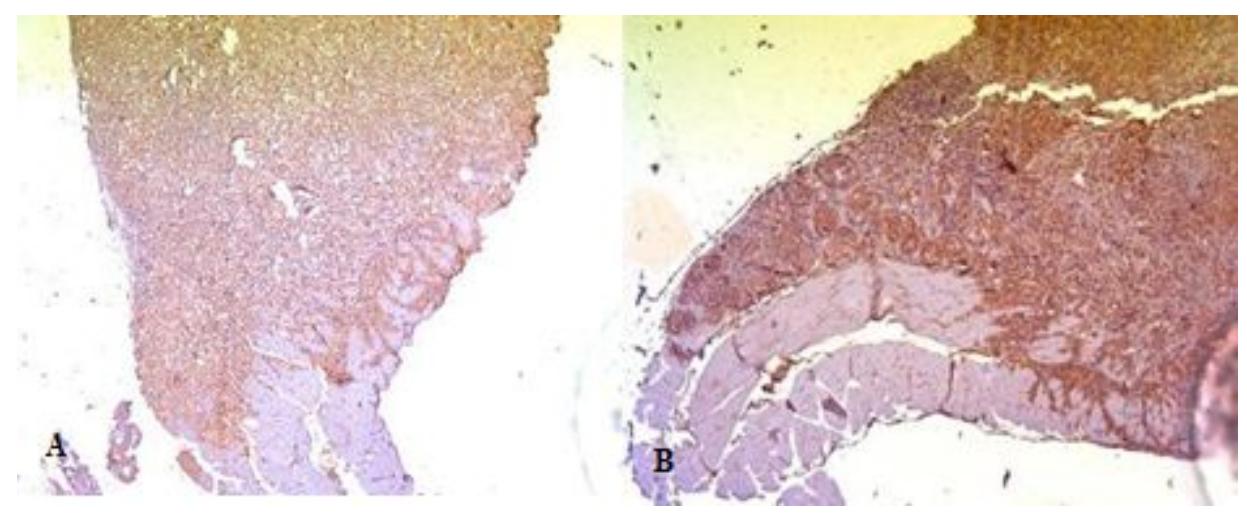

Figura 27: Reação de imunhistoquímica utilizando o anticorpo anti-b-catenina. A: tumor de animal do grupo MCF7, com marcação difuso fraco; B: tumor de animal do grupo no grupo cocultura $90 \%$ MCF7+10\%MSC, com marcação forte e difuso. 


\subsection{Ensaio de viabilidade por MTT}

Foi realizado ensaio de MTT para avaliar uma possível citotoxidade associada a meio condicionado de células MSC.

O controle de morte foi diferente estatisticamente de todas as culturas. O controle de vida não se diferenciou de nenhuma das culturas do experimento, exceto do controle de morte.

As culturas apresentaram índice de viabilidade superior quando comparada com o controle de vida, demonstrando que o meio condicionado de MSC não provoca citotoxidade com as culturas apresentadas e auxilia na viabilidade destas culturas, conforme demonstrado no gráfico 8 abaixo.

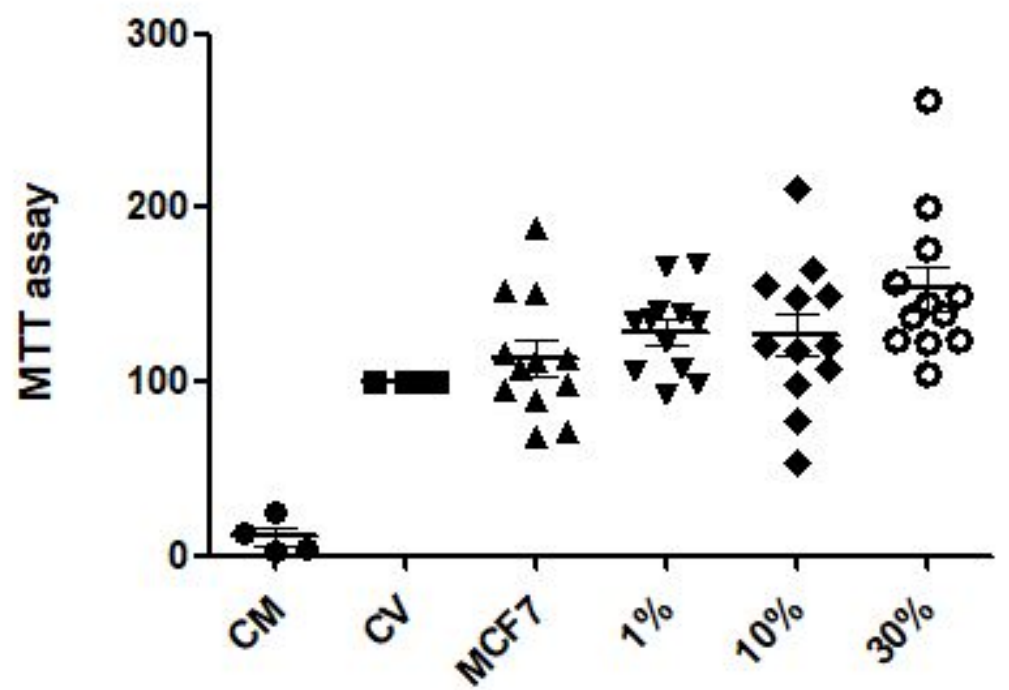

Gráfico 8: ensaio de viabilidade MTT utilizando o estímulo do meio condicionado de MSC previamente por 1 hora.

4.11 Ensaio de MTT para avaliação da proteção contra a produção de radicais livres e espécies de oxigênio reativas (ROS), induzidos pelo peróxido de hidrogênio $\left(\mathrm{H}_{2} \mathrm{O}_{2}\right)$.

Foi realizado MTT estímulo por 1 hora com peróxido de hidrogênio.

A utilização deste teste auxiliou o entendimento de proteção celular frente ao estresse oxidativo após estímulo com peróxido de hidrogênio. 
Células MCF-7 em contato com células MSC permitiu proteção frente a ação deletéria conferida pelo estresse oxidativo, medida que as culturas com células MSC impedem ou diminuem a ação dos radicais livres.

Ao analisar o controle de vida, sem utilização de peróxido de hidrogênio, em comparação com outras culturas foi observado que células MCF-7 cultivadas com $30 \%$ de células MSC expostas por 1 hora ao meio condicionado de MSC e posteriormente expostas a peróxido de hidrogênio, apresentaram índice de sobrevivência similar ao controle de vida, sendo estas culturas com $70 \%$ de MCF-7 e $30 \%$ de MSC menos susceptíveis aos danos provocados pelo estresse oxidativo.

Todas as demais culturas $1 \%, 10 \%$ e $30 \%$ apresentaram diferença frente ao controle de vida(CV) $p<0.0001$. Da mesma forma todas as culturas foram diferentes do controle de morte $(C M) p<0.0001$.

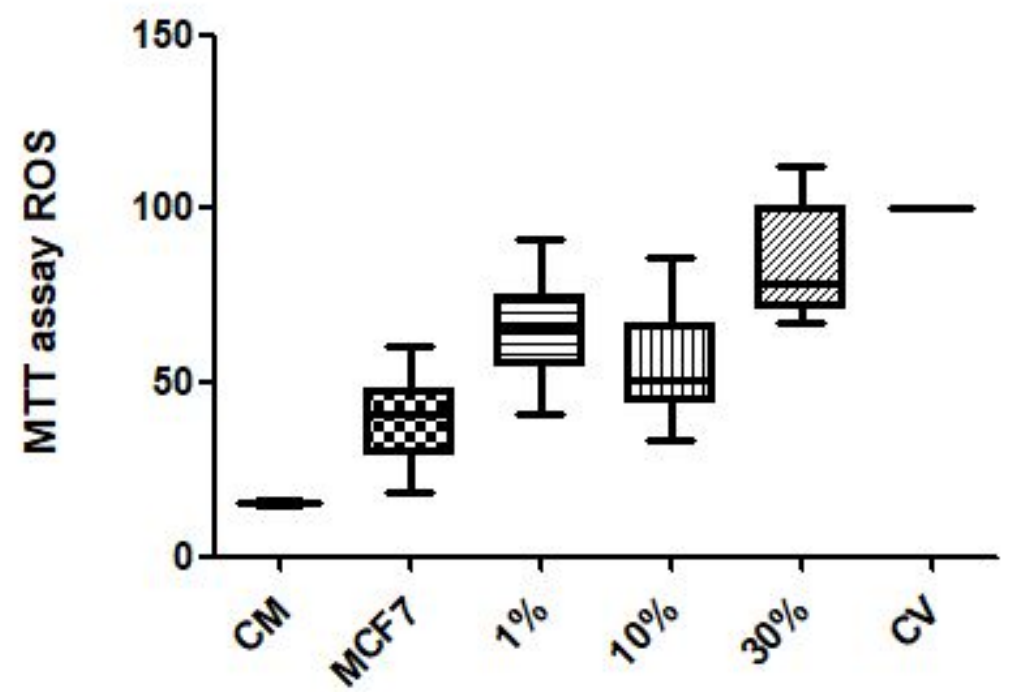

Gráfico 9: Ensaio de viabilidade MTT após o estímulo de uso de $\mathrm{H}_{2} \mathrm{O}_{2}$

\subsection{Western Blotting quebra de DNA.}

O teste de avaliação de dano de DNA para verificar sobrevivência celular diante a exposição da célula MCF-7 em cocultura com MSC e seu meio condicionado, na manutenção de cromatina e dano celular para verificação da estabilidade biológica. $O$ ensaio mostrou alta estabilidade de cromatina, refletindo baixa atividade de reparação de DNA em células 
MSC. A cocultura de $30 \%$ MSC e $70 \%$ MCF-7 mostrou com mesmo índice de reparação da célula MSC isolada.

Células MSC demostraram maior estabilidade na reparação de DNA e coculturas $1 \%, 10 \%$ e $30 \%$ se comportaram de forma diferente que células MCF-7 isoladas, apresentando um índice gradativo que quanto mais células MSC apresentou a cocultura, maior o índice de estabilidade de cromatina, baixo índice de dano e reparação de DNA.

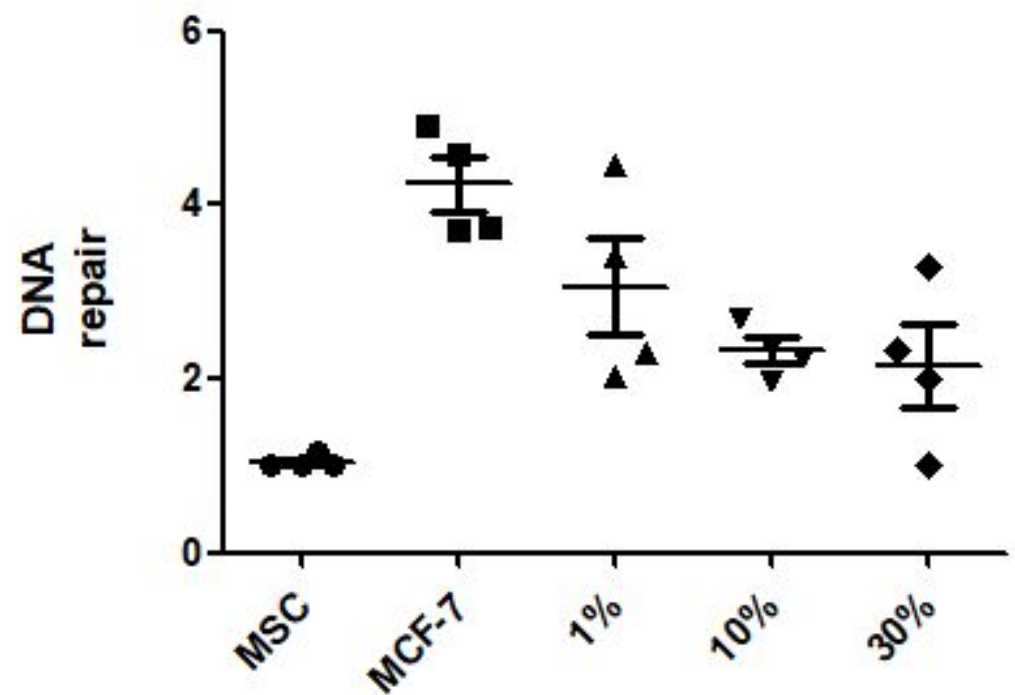

Gráfico 10: Ensaio de viabilidade Western Blotting com uso de H2AX para avaliação no dano de DNA.

\subsection{Western Blotting núcleo e citoplasma.}

Foram realizados avaliação do perfil de expressão da proteína e-caderina pelo ensaio de Western blot em célula total lisada e em sua porção citoplasmática. Células MCF-7 em coculturas foram passadas por sorting, lisadas e separados seus conteúdos celulares em célula total e citoplasma, o mesmo procedimento ocorreu com a linhagem MCF-7 sem estímulo de MSC.

Foi observado mudança do perfil de expressão proteica de e-caderina em citoplasma de cocultura $30 \%$. 


\section{E-Caderina} GAPDH

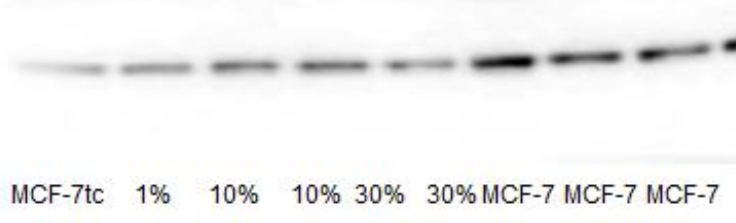

Figura 28: WB de lise celular MCF-7(total cell) e em sequencia 1\%, 10\%, 30\% e MCF-7 citoplasma para a proteína E-caderina. 


\section{DISCUSSÃO}

O câncer de mama é uma doença heterogênea que é caracterizada por ter caráter maligno das células epiteliais da mama e é capaz de sofrer metástase a distantes áreas do corpo. Este câncer pode ser dividido em cinco grandes grupos: receptor de hormônio positivo: luminal $A$ e B; receptor de hormônio negativo: normal breast-like, HER-2+ e basal-like (Russo and Russo 2004).

Os tipos luminais tem características de apresentarem células tumorais em contato com o lúmen dos ductos mamários, tendo então os mesmos marcadores na camada luminal epitelial que células ductais de mama. Os tipos Luminal A e B distinguem se que A apresenta alta expressão de receptor de estrógeno (ER), e baixa expressão de genes de proliferação enquanto que o subtipo $B$ apresenta ER expresso em baixo nível e alto índice proliferativo.

A linhagem de célula com caráter epitelial MCF-7 derivada do Michigan Cancer Foundation-7 em 1973 originada de uma efusão pleural de paciente com 69 anos com patologia de carcinoma invasivo ductal é uma linhagem com fenótipo tumoral, aderente ao substrato, ER+. Apresenta característica cuboidal, com padrão de presença de microvilos, acúmulo de vesículas secretórias, presença de desmossomos, tonofilamentos e lúmen intracitoplasmático (Soule, Vazguez et al. 1973, Burdall, Hanby et al. 2003, Russo and Russo 2004).

\subsection{Mudança do perfil de marcadores de superfície celular.}

Marcadores de superfície celular são utilizados para descrever células tronco tumorais em diferentes tipos de câncer (Albini and Sporn 2007).

O marcador de superfície celular CD44+ é uma glicoproteína que está envolvido com proliferação celular, diferenciação, migração, angiogênese e sobrevivência, este marcador em conjunto com CD24- é 
utilizado para adquirir e isolar células tronco tumorais (Naor, 2002), fornecendo a comunicação entre citoesqueleto, membrana plasmática regulando a morfologia e motilidade celular.

Células MCF-7 apresentam alta expressão de CD24 e quantidades negativas ou pouco detectáveis de CD44, sendo facilmente detectável por citometria de fluxo (Albini and Sporn 2007).

Dados adquiridos, neste estudo, nas culturas por citometria de fluxo mostraram modificação do perfil isolado de células MCF-7 que quando cultivadas juntamente com células mesenquimais modificaram seu perfil para CD44 ${ }^{\text {high }} / C D 24^{\text {low }}$, sendo comparativamente diferentes que células MCF-7 cultivadas sozinhas, este perfil de células com marcadores CD44+/24- apresentam características mesenquimais a tumores.

O perfil CD44 high/CD24 $4^{\text {low }}$ em câncer de mama está fortemente associado com perfil de stem cell, com células tumorais mais indiferenciadas e invasivas (Uchino et al. 2010, Shackleton et al. 2006), esses dados obtidos na avaliação do perfil celular por citometria de fluxo são equivalentes a evidenciar o "ganho" do perfil tronco à linhagem de células de tumor epitelial MCF-7, que somados a outros achados comprovam a mudança de perfil somente epitelial para stem cell, com isso pode-se associar este perfil a maior capacidade migratória, invasiva e com marcadores de maior agressividade tumoral.

\subsection{Aumento do número de mamoesferas e mudança de marcador.}

Ao realizar o teste de mamoesferas é possível adquirir informações acerca de características da cultura celular investigada. Comparando-se o ensaio de mamoesferas com ensaio de cultura em 3D é possível verificar a forma irregular do aglomerado celular, sendo completamente distinto que no ambiente de cultivo em 2D.

O modelo de emprego do ensaio de mamoesferas torna possível também mimetizar o pequeno nicho da glândula mamária ou de tumores, 
sendo possível avaliar, contar, mapear, isolar células específicas, como por exemplo com características tronco com perfil CD44+/CD24-.

Este trabalho foi possível quantificar que a influência de MSC em contato com a célula tumoral MCF-7 para o aumento do número de mamoesferas comparado com MCF-7 isoladamente, sendo que as coculturas com 10 e $30 \%$ de células MSC influenciam o aumento de mamoesferas, a cocultura $1 \%$ não apresentou mudanças no número de mamoesferas.

Uma das explicações trazidas por Ito e colaboradores trabalha a explicação para a formação de mamoesferas influenciada pela interação com MSC. O autor coloca que MSC podem secretar EGF, assim como estimular a ativação de receptores de EGF, modulando desta forma a proliferação de mamoesferas (Ito, Zimdahl et al. 2012). A proteína EGF, da sigla em inglês epidermal growth factor, tem função de proliferação e migração celular, sua mutação e atividade aumentada está associada incidência de câncer (Tomas et al. 2014).

Foi encontrado o perfil tronco tumoral em mamoesferas de células MCF-7 adquirido por citometria de fluxo por marcação CD44+/CD24- com o estímulo de $1 \%, 10 \%$ e $30 \%$ de células MSC.

\subsection{Teste de invasão e migração celular por estímulo de MSC e} de seu meio condicionado.

Células mesenquimais são requeridas constantemente para reparo, regeneração, proliferação, manutenção da função morfológica durante a vida. Neste trabalho foi quantificado o fechamento da ferida de WH com o estímulo do cultivo de células MCF-7 com células MSC, sendo que a influência de MSC e seu meio condicionado mostraram a reorganização da colônia em migração em células tumorais MCF-7.

A linhagem celular MCF-7 é considerada pouco agressiva, invasiva e com baixo potencial metastático. O estímulo com células e meio condicionado de MSC, $10 \%$ e $30 \%$ fez com que células MCF-7 
migrassem, avaliado pelo ensaio de wound healing, e fechassem a confluência do poço no ensaio sob estímulo, porém nossos dados não apresentaram diferença estatística por variações no ensaio, trazendo a dedução que o estímulo não trouxe modificações no potencial migratório porém acompanhou a hipótese do estudo, que a condição de existência de MSC e seu meio condicionado promovem mudança de perfil de marcadores celulares CD44 high/CD24 low e geram mudanças neste microambiente tumoral.

A identificação da quimiotaxia que influencia MCF-7 em sua capacidade migratória e de invasão se torna importante para elucidar o potencial de agressividade proporcionado pela influência de MSC em conjunto ou em contato com células tumorais.

Os achados encontrados neste trabalho estão em consonância com os trabalhos de Ito e colaboradores que avaliaram o potencial proliferativo in vivo de células tumorais em interação com MSC provindas da medula óssea (Ito, Zimdahl et al. 2012).

Para a avaliação do potencial de invasão foi utilizado o ensaio com a câmara de Boyden que dispõe de uma câmara com dois compartimentos separada por um filtro com microporos, a fim de avaliar a quimiotaxia, motilidade celular e capacidade de invasão (Russo and Russo 2004), empregando uma matriz extracelular conhecida como Matrigel.

A capacidade de células ultrapassarem a barreira oferecida por Matrigel e por pequenos poros por estímulos quimiotáticos podem contribuir para avaliação do potencial invasão e progressão das células tumorais. Este desempenho assemelha-se ao comportamento biológico in vivo durante a metástase, sendo necessário de que células metastáticas migrem e degradem a membrana basal e o estroma subjacente (Benton et al. 2011).

Este trabalho foi possível quantificar células que invadiram o Matrigel a fim de avaliar quais estímulos foram capazes de provocar maior influxo de células tumorais neste experimento. 
O estímulo do meio condicionado de MSC foi importante para aumentar a invasão de células tumorais MCF-7. Da mesma forma o meio condicionado de da cocultura de 99\%MCF-7 e 1\% de MSC mostrou aumentar o potencial de invasão de células MCF-7.

Esta pesquisa trabalhou formas de entendimento sobre 0 comportamento celular de tumores in vitro a fim de trazer respostas que podem ser utilizadas no melhor adequação de terapias alvo pautadas na observação de fenomenologia do câncer. É sabido que as metástases são responsáveis por $90 \%$ das mortes por câncer, apesar dessa significância clínica, o entendimento dos mecanismos celular e molecular ainda são pouco compreendidos (Albini and Sporn 2007).

A plasticidade celular em células tronco é um facilitador no estado de transição epitélio mesênquima, o que vem sendo postulado como um importante evento durante a fase inicial da metástase do câncer (Thiery et al. 2003).

É importante ressaltar que nenhum estímulo foi completo em aumentar a invasão de células MCF-7 a ponto de serem mais agressivas que o estímulo oferecido pelo SBF, no entanto a avaliação da mudança do comportamento celular frente a quimiotaxia oferecida pelo meio condicionado de MSC foi suficiente para quantificar que células MCF-7 invadem e migram mais quando em contato com o meio condicionado de MSC.

\subsection{A cultura em gel de colágeno 3D.}

O ensaio de cultura em 3D representa um grande significado no estudo de modelos de câncer mimetizando o microambiente in vivo de células tumorais, sendo uma ferramenta de caracterização das células estudadas.

A morfologia das células em $2 \mathrm{D}$ apresentam diferenças nas caracterizações celulares por estarem ancoradas ao material de poliestireno, células crescem em modelo plano, apresentando formado 
em monocamada, com interação celular baseada em estímulos célula a célula. Embora usualmente empregada pela facilidade em experimentação e pela rotina bem estabelecida de protocolos para pesquisação, a resposta obtida pela cultura $2 \mathrm{D}$ porventura pode estar minimizada se comparada a modelos 3D (Dhimolea et al. 2010).

Neste trabalho foi realizado experimento utilizando matriz de colágeno para mimetizar o microambiente de interação celular de células MCF-7 com células mesenquimais para avaliar mudanças de perfil durante a transição epitélio mesênquima.

No experimento adotado, foi realizado um "sanduíche" composto por colágeno-células-colágeno, ao qual foi avaliado por 7 dias 0 comportamento celular frente a invasão e a morfologia celular. Nota-se que células MCF- 7 cocultivadas com $1 \%$ de células MSC apresentam fenótipo arredondado, apresentando 2,63 de invasão, formando poucas colônias de grande diâmetro.

Culturas com $10 \%$ de MSC invadiram em média 2,05 da matrix de colágeno, apresentarem menos interação célula-célula distinguindo-se pela formação de colônias espalhadas pelo substrato e menores. Culturas com $30 \%$ de MSC invadiram a matriz de colágeno de forma distinta dos demais estímulos, formando pequenos aglomerados celulares com média de 1,20 de invasão da matriz de colágeno, apresentaram menor interação epitelial, caracterizado pelo fenômeno EMT, demonstrando a plasticidade que a interação com MSC promove.

A análise da formação de tumores evidenciada pela visão macroscópica retirada por lupa mostra o perfil de microtumores em diferentes níveis de invasão da matriz de colágeno. O menor estímulo ofertado por interação a MSC promove um aglomerado celular mais robusto, com poucas colônias enquanto maior estímulo a MSC promove menores colônias, em diferentes níveis no plano vertical do colágeno, estando mais espalhadas.

A avaliação do modelo de crescimento em cultura 3D forneceu dados não obtidos até o momento em literatura sobre a interação de 
MCF-7 com MSC. Com o modelo 3D é possível observar o movimento da cultura celular de forma detalhada a fim de aumentar a espacialidade advinda pelo microambiente, tendo as células possibilidade de migrar então para diferentes direções, sendo os dados importantes complementos aos achados obtidos também pelo modelo em 2D.

\subsection{Crescimento de colônias na capacidade de proliferação} celular.

O ensaio clonogênico é um excelente mecanismo de avaliação do crescimento celular de forma a avaliar o crescimento da colônia para determinados estímulos, obtendo então uma resposta clara para o comportamento biológico do tumor.

Neste trabalho o ensaio clonogênico apresentou maior atividade de crescimento de colônia entre os grupos. Este índice de crescimento é esperado em tumores agressivos, como o câncer de mama metastático (Albini and Sporn 2007), o resultado em número de colônias e em tamanho de colônias, revela que a interação de células MCF-7 com MSC diminui o tamanho das colônias, demonstrando então a capacidade aumentada das colônias estimuladas por MSC em sua capacidade proliferativa, assim como realizado no estudo de Fedr e colaboradores, que utilizou deste recurso para identificar a capacidade clonogênica e proliferativa de células tronco cancerígenas de amostras biológicas de pacientes e linhagens celulares (Fedr et al.2013).

Este resultado assemelha-se aos dados obtidos em cultura 3D, a medida que a maior interação com MSC muda a habilidade de divisão e formação de colônias de células tumorais, estando estas em número e tamanho distintos de células tumorais de câncer de mama MCF-7 isolados.

O teste de MTT, ensaio de avaliação colorimétrica de atividade metabólica celular, é um aliado a fim de quantificar o índice de proliferação e viabilidade produzido por determinados estímulos. Neste 
trabalho foi possível verificar o estímulo produzido pelo meio condicionado de MSC às culturas de MCF-7 e coculturas revelaram aumento da capacidade de viabilidade celular.

A capacidade proliferativa de uma população específica é requerida para avaliar seu potencial metastático. Somando os dados deste experimento com aumento de marcadores CD44+/CD24- nas populações em cocultura, aumento de migração, invasão, mudança de perfil de colônias em 3D é possível incumbir o fenômeno epitélio mesênquima pautado no estímulo por MSC e seu subproduto para a modificação do microambiente tumoral.

\subsection{Mudanças de marcadores celulares.}

A transição epitélio mesênquima é correlata com fenótipo mais agressivo de câncer de mama, alterando o perfil celular tumoral, com perda de características epiteliais, alteração de marcadores celulares, perda de adesão celular e aumento de migração e invasão à corrente sanguínea e tecidos adjacentes (Christiansen, 2006).

Durante a progressão tumoral as proteínas envolvidas com fenótipos epiteliais são descoladas para o citoplasma e núcleo celular, podendo a expressão destas proteínas estão aumentadas em tumores metastáticos.

Ao avaliar a expressão de E-caderina com base no tamanho da metástase Chao, Y. et al, 2012 verificou que maiores focos de metástase apresentaram menor expressão de E-caderina de membrana. O autor ressalta a importância do fenômeno EMT para a plasticidade celular como mecanismo contínuo de reposicionamento da célula tumoral proporcionando vantagem sobre a sobrevivência e a disseminação (Chao, Wu et al. 2012).

Este trabalho foi realizado marcação com 0 anticorpo anti-ecaderina para células MCF-7 em diversos estímulos com células MSC e junto ao seu meio condicionado. Esta avaliação levou a reproduzir 
a localização desta caderina com mudança de sua co-localização conforme estímulo de células MSC. A influência de células MSC mostrou mudança do perfil de marcação de E-caderina de membrana para citoplasma e preferencialmente núcleo.

A perda de E-caderina em membrana favorece não somente um distúrbio na junção celular célula-célula, mas também permite a perda da arquitetura celular normal (Wells, Yates et al. 2008).

Rubin et al, 2001 realizou em seu trabalho avaliação de TMA de tumores de próstata metastáticos. $O$ autor infere que a expressão de E-caderina apresenta-se em estados de regulação transitória, uma vez que em sua amostragem a E-caderina é expressa em tumores em fase inicial, marcação alta em tumores maiores e por fim tumores metastáticos apresentaram marcação vasta em toda sua amostragem sendo apenas alguns casos a expressão de $\mathrm{E}$-caderina se encontra aberrante. $\mathrm{O}$ autor coloca também a ausência ou baixa expressão proteica em imunohistoquímica do marcador de Vimentina em sua amostragem (Rubin, Mucci et al. 2001).

No câncer de mama metastático também foi mostrado aumento da expressão proteica de E-caderina em comparação com tumores primários. Tumores podem vir a reexpressar E-caderina pelo fato de células metastáticas apresentarem plasticidade celular devido fenômeno da EMT. A adesão celular e a motilidade celular usualmente são re vistas como opostas no fenômeno epitélio mesênquima (Wells, Yates et al. 2008).

A $\beta$-catenina na superfície celular, juntamente com a E-caderina é muito importante para a supressão da migração de invasão de células cancerígenas pautado na estabilização da junção celular.

A $\beta$-catenina pertence a família do complexo de aderência caderina/catenina de junções celulares, estabilizando o contato célula-célula. Esta proteína está associada a E-caderina, ambas dependentes da molécula de $\mathrm{Ca}^{2+}$ na adesão celular. 
A proteína $\beta$-catenina está preferencialmente localizada na membrana celular em sua maior parte, o perfil basal epitelial de células de câncer apresentam geralmente marcação positiva desse anticorpo. A localização da $\beta$-catenina na membrana celular em células cancerígenas mostrou ser importante na supressão da invasão e migração tumoral, uma vez que faz parte da estabilidade da junção células (Brabletz, Jung et al. 2001).

A mudança da co-localização celular da expressão de $\beta$-catenina de membrana para núcleo e citoplasma está associada ao fenótipo invasivo, enquanto o perfil de expressão de membrana e citoplasma está envolvido com fenótipo epitelial (Chao, Wu et al. 2012).

O marcador $\beta$-catenina nuclear foi associado a estudos com amostras teciduais de pacientes com metástase óssea comparados a câncer sem metástase (Calvi, Adams et al. 2003). O marcador $\beta$-catenina na membrana de células tronco previnem a ativação da via canônica de sinalização Wnt, sendo a $\beta$-catenina o mediador desta via.

$\mathrm{Da}$ mesma forma as marcações com o anticorpo $\beta$-catenina adquiridas no multifoton mostraram marcação em citoplasma e núcleo em células MSC e na cocultura $30 \%$ MSC $70 \%$ MCF-7, com perfil diferenciado de marcação em células MCF-7 e em outras coculturas, as células MCF-7 foram discriminadas por apresentarem GFP+, sendo a marcação em membrana predominante nestas culturas. Consequentemente o perfil CD44+ e a mudança de co-localização de $\beta$-catenina são perfis importantes em tumores metastáticos (Sorlie, Wang et al. 2006).

A proteína E-caderina e $\mathrm{N}$-caderina compartilham características estrutural e funcional, compartilhando a função de estabelecer a adesão celular, ambos são expressos em superfície celular e apresentam dependência do canal de cálcio.

$\mathrm{N}$-caderina inibe a protrusão celular, controlando a direção onde a célula irá migrar. A característica de existir uma reduzida ação de adesão focal desta proteína produz uma significativa diminuição da aderência 
focal nas junções intracelulares, está aumentada em células em transição epitélio mesênquima (Wells, Yates et al. 2008).

Para Gumbiner a expressão de caderinas, sendo esta uma resistência a adesão, influenciam no comportamento e classificação das células, independente do tipo de caderina expresso (Gumbiner 2005).

A expressão de $\mathrm{N}$-caderina em células MCF-7 foram nulas neste trabalho, enquanto células MSC apresentavam marcação para este anticorpo predominantemente em membrana. Houve marcação em células MCF-7 cultivada com $30 \%$ de MSC, selecionada por expressar GFP+. Esta marcação foi presente somente em células MCF-7 quando exposta por 5 dias com células MSC.

A quantidade de expressão e a localização da proteína de adesão celular $\mathrm{N}$-caderina pode determinar a classificação do perfil celular (Gumbiner 2005). Neste estudo foi quantificado a presença de N-caderina sendo modificada sua apresentação em células MCF-7 expostas a células MSC e seu subproduto.

\subsection{Imunohistoquimica.}

Os testes in vivo não apresentaram diferenças entre o número de tumores coletado e tamanho avaliados, no entanto devido ao pequeno número de animais é difícil estabelecer uma conclusão relativa ao crescimento tumoral, comprometendo hipóteses sobre o tema. As amostras retiradas foram marcadas com a reação de imunohistoquímia para os anticorpos anti e-caderina, vimentina e $\beta$-catenina.

Os resultados obtidos com a imunomarcação sugerem que a expressão diminuída de e-caderina predispõe maior potencial infiltrativo e invasivo aos tecidos periféricos. Da mesma forma a indicação de aumento da expressão de vimentina e $\beta$-catenina denota potencial mais agressivo e infiltrativo de células tumorais, indicando promoção da transição epitélio mesenquima nos animais com tumores provindos da cocultura com células mesenquimais. 
Embora promissores, tanto testes in vivo quanto realização e análise de marcadores relacionados com a transição epitélio mesenquima por imunohistoquímica em tumores de cobaias carecem mais números de indivíduos para fechamento de hipótese, sendo este um fator limitante deste estudo. Desta forma os resultados obtidos não suportam conclusão e sim um indicador, as ser avaliado a posteriori ou comparado com outras evidências na literatura.

5.8 Ensaio de MTT para avaliação da proteção contra a produção de radicais livres e espécies de oxigênio reativas (ROS), induzidos pelo peróxido de hidrogénio $\left(\mathrm{H}_{2} \mathrm{O}_{2}\right)$.

O ensaio colorimétrico com peróxido de hidrogênio apresenta resultados para compreensão da proteção celular frente a uma fonte de stress. A apoptose é um mecanismo fisiológico de proteção a células normais, populações celulares com perfil metastático tendem a ser mais resistentes a apoptose. Esta afirmação trabalhada por Eccles e colaboradores vai de encontro com a teoria que a transição epitélio mesenquimal apresenta mudanças na motilidade celular e resistência a apoptose (Eccles et al. 2007).

Os achados encontrados após estímulo frente a proteção contra apoptose a partir da proteção contra produção de radicais livres e espécies reativas de oxigênio foram em todas as coculturas $1 \%, 10 \%$ e $30 \%$ de estímulo por MSC e estas apresentaram-se diferentes do controle de morte. O estímulo com peróxido a MCF-7 deixou a cultura com mesmo índice de apoptose que o controle de morte. Apenas a cocultura $30 \%$ de MSC apresentou mesmo índice de vida que a cultura sem o estímulo ao peróxido de hidrogênio.

Todos estes dados conferem resposta sob análise quantitativa acerca da proteção sobre a apoptose em células tumorais quando em contato por 5 dias com células mesenquimais em diferentes concentrações, ou seja, células mesenquimais desempenham papel de 
sobrevivência ao tumor, incremento fundamental para o processo de disseminação e metástase de células tumorais em um ambiente fisiológico.

Espécies reativas de oxigênio (ROS) interagem com o DNA, estes podem causar uma oxidação das bases do DNA o que levaria a um pareamento incorreto de bases ou a quebra do DNA. Fatores exógenos e o produto do metabolismo celular ocasionam esses fatores. A instabilidade celular relacionada do dano de DNA provocado pelo peróxido de hidrogênio e a produção de espécies reativas de oxigênio pode estar associados a indução e transformação de malignidade celular.

No trabalho de Kim et al o uso de peróxido de hidrogênio promove a EMT via HIF-1 $\alpha$ e TGF- $\beta 1$, além de aumentar genes relacionados a sobrevivência e proliferação, sendo desta forma que ROS contribui para carcinogênese (Soon, Kim et al. 2013). A ativação de HIF-1 tem um papel importante na resistência a apoptose, invasão, metástase, angiogênese e imortalização, estando a expressão de HIF-1 associado ao aumento de mortalidade por câncer (Semenza et al. 2003).

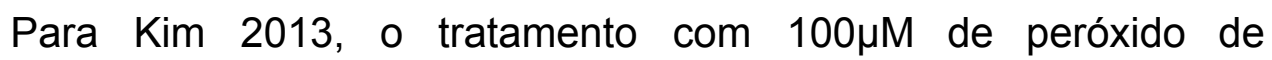
hidrogênio aumentou o nível de expressão de SLUG e TWIST-1 e diminuiu a expressão de E-caderina em células malignas de mesotelioma HM513 (Soon, Kim et al. 2013).

Este trabalho trouxe algumas respostas quanto a influência de peróxido em células de câncer estimuladas com células mesenquimais e seu meio condicionado, obviamente muitas perguntas poderiam ser feitas e respondidas em futuros estudos acerca deste tema.

\subsection{Dano e reparação de DNA em células de câncer de mama em contato com MSC e seu meio condicionado.}

Basicamente células do corpo sofrem danos em seu DNA, caso não ocorra reparação esta instabilidade contribui para anormalidade que pode favorecer a apoptose celular, ocorrendo alguma resistência a 
apoptose ocorre o comprometimento da função celular, podendo então estar relacionada com mutações e com o desenvolvimento do câncer. Esse dano pode ser devido a fatores exógenos, como radiação, quimioterapia ou agentes ambientais ou endógenos como reações do próprio metabolismo intracelular (Ali, Rakha et al. 2016).

A integridade do DNA é mantida pela replicação do DNA com exatidão ou o reparo de DNA. Sendo a ativação de via de reparo se torna uma ferramenta para manutenção celular. Células mesenquimais apresentam baixo índice de reparação de DNA, apresentando alta estabilidade de cromatina.

Bao et al, 2006 em seu trabalho mostra resistência a radioterapia em células tronco tumorais preferencialmente devido ao controle de dano do DNA e aumento na capacidade de reparação de DNA (Bao et al. 2006).

Neste trabalho foi realizado estudo sobre quebra e reparação de DNA comparativamente com células MCF-7 e em contato com células MSC. Houve uma gradação na estabilidade celular relativa a função de reparação de DNA, ou seja, quanto maior o contato por cocultura de células MCF-7 com MSC maior foi a estabilidade celular.

Estes dados fornecem resposta importante sobre o perfil do microambiente de contato de células cancerígenas juntamente com células mesenquimais, acarretando então células de câncer de mama MCF-7 a apresentarem maior estabilidade de DNA quando cocultivadas com células MSC. Seria interessante utilizar células MCF-7 com perfil tronco CD44+/CD24- para avaliar se este resultado se estabeleceria na mesma condição com células com perfil tronco tumoral, porém hipótese de novo teste poderá ser realizado em futuros estudos. 


\section{CONCLUSÃO}

A influência de células mesenquimais e seu meio condicionado levou a modificações no comportamento celular de células MCF-7 em:

- Mudança de marcadores por avaliação por imunocitologia de E-caderina, b-catenina, ausência de expressão de n-caderina e vimentina;

- $\quad$ Mudança de perfil de marcadores CD44+/CD24-;

- Considerável aumento do potencial migratório de células tumorais MCF-7;

- Aumento do potencial de invasão de células tumorais MCF-7;

- $\quad$ Aumento do número de mamoesferas e mudança de perfil CD44+/CD24- em células MCF-7;

- $\quad \mathrm{MSC}$ e seu meio condicionado influenciaram no crescimento e tamanho das colônias observados em 2D e em 3D;

- $\quad$ MSC e seu meio condicionado auxiliam no aumento da viabilidade celular por MTT;

- $\quad$ MSC e seu meio condicionado forneceram proteção a apoptose a partir da proteção contra produção de radicais livres e espécies reativas de oxigênio;

- A célula MSC e seu meio condicionado oferecem maior estabilidade celular sobre quebra e reparação de DNA;

- Dados insuficientes para conclusão de mudanças marcadores relacionados a EMT in vivo. 
Referências Bibliográficas

Abraham, B. K., P. Fritz, M. McClellan, P. Hauptvogel, M. Athelogou and H. Brauch (2005). "Prevalence of CD44+/CD24-/low cells in breast cancer may not be associated with clinical outcome but may favor distant metastasis." Clin Cancer Res 11(3): 1154-1159.

Al-Hajj, M., M. S. Wicha, A. Benito-Hernandez, S. J. Morrison and M. F. Clarke (2003). "Prospective identification of tumorigenic breast cancer cells." Proc Natl Acad Sci U S A 100(7): 3983-3988.

Albini, A. and M. B. Sporn (2007). "The tumour microenvironment as a target for chemoprevention." Nat Rev Cancer 7(2): 139-147.

Ali, R., E. A. Rakha, S. Madhusudan and H. E. Bryant (2016). "DNA damage repair in breast cancer and its therapeutic implications." Pathology.

Beerling, E., D. Seinstra, E. de Wit, L. Kester, D. van der Velden, C. Maynard, R. Schafer, P. van Diest, E. Voest, A. van Oudenaarden, N. Vrisekoop and J. van Rheenen (2016). "Plasticity between Epithelial and Mesenchymal States Unlinks EMT from Metastasis-Enhancing Stem Cell Capacity." Cell Rep 14(10): 2281-2288.

Bhowmick, N. A., E. G. Neilson and H. L. Moses (2004). "Stromal fibroblasts in cancer initiation and progression." Nature 432(7015): 332-337.

Blanco, M. J., G. Moreno-Bueno, D. Sarrio, A. Locascio, A. Cano, J. Palacios and M. A. Nieto (2002). "Correlation of Snail expression with histological grade and lymph node status in breast carcinomas." Oncogene 21(20): 3241-3246.

Brabletz, T., A. Jung, S. Reu, M. Porzner, F. Hlubek, L. A. Kunz-Schughart, R. Knuechel and T. Kirchner (2001). "Variable beta-catenin expression in colorectal cancers indicates tumor 
progression driven by the tumor environment." Proc Natl Acad Sci U S A 98(18): 10356-10361.

Burdall, S. E., A. M. Hanby, M. R. Lansdown and V. Speirs (2003). "Breast cancer cell lines: friend or foe?" Breast Cancer Res 5(2): 89-95.

Calvi, L. M., G. B. Adams, K. W. Weibrecht, J. M. Weber, D. P. Olson, M. C. Knight, R. P. Martin, E. Schipani, P. Divieti, F. R. Bringhurst, L. A. Milner, H. M. Kronenberg and D. T. Scadden (2003). "Osteoblastic cells regulate the haematopoietic stem cell niche." Nature 425(6960): 841-846.

Calza, S., P. Hall, G. Auer, J. Bjohle, S. Klaar, U. Kronenwett, E. T. Liu, L. Miller, A. Ploner, J. Smeds, J. Bergh and Y. Pawitan (2006). "Intrinsic molecular signature of breast cancer in a population-based cohort of 412 patients." Breast Cancer Res 8(4): R34.

Campbell, L. L. and K. Polyak (2007). "Breast tumor heterogeneity: cancer stem cells or clonal evolution?" Cell Cycle 6(19): 2332-2338.

Chao, Y., Q. Wu, C. Shepard and A. Wells (2012). "Hepatocyte induced re-expression of E-cadherin in breast and prostate cancer cells increases chemoresistance." Clin Exp Metastasis 29(1): 39-50.

Charafe-Jauffret, E., C. Ginestier, F. lovino, C. Tarpin, M. Diebel, B. Esterni, G. Houvenaeghel, J. M. Extra, F. Bertucci, J. Jacquemier, L. Xerri, G. Dontu, G. Stassi, Y. Xiao, S. H. Barsky, D. Birnbaum, P. Viens and M. S. Wicha (2010). "Aldehyde dehydrogenase 1-positive cancer stem cells mediate metastasis and poor clinical outcome in inflammatory breast cancer." Clin Cancer Res 16(1): 45-55.

Cowin, P., T. M. Rowlands and S. J. Hatsell (2005). "Cadherins and catenins in breast cancer." Curr Opin Cell Biol 17(5): 499-508. 
Djouad, F., P. Plence, C. Bony, P. Tropel, F. Apparailly, J. Sany, D. Noel and C. Jorgensen (2003). "Immunosuppressive effect of mesenchymal stem cells favors tumor growth in allogeneic animals." Blood 102(10): 3837-3844.

Dominici M, Le Blanc K, Mueller I, Slaper-Cortenbach I, Marini F, Krause D, Deans R, Keating A, Prockop Dj, Horwitz E. Minimal criteria for defining multipotent mesenchymal stromal cells. The International Society for Cellular Therapy position statement. Cytotherapy. 2006;8(4):315-7.

Ginestier, C., M. H. Hur, E. Charafe-Jauffret, F. Monville, J. Dutcher, M. Brown, J. Jacquemier, P. Viens, C. G. Kleer, S. Liu, A. Schott, D. Hayes, D. Birnbaum, M. S. Wicha and G. Dontu (2007). "ALDH1 is a marker of normal and malignant human mammary stem cells and a predictor of poor clinical outcome." Cell Stem Cell 1(5): 555-567.

Gumbiner, B. M. (2005). "Regulation of cadherin-mediated adhesion in morphogenesis." Nat Rev Mol Cell Biol 6(8): 622-634.

Hanahan, D., Weinberg, R. A. (2000). The hallmarks of cancer. Cell, 100(1): 57-70.

Huang, M., Y. Li, H. Zhang and F. Nan (2010). "Breast cancer stromal fibroblasts promote the generation of CD44+CD24- cells through SDF-1/CXCR4 interaction." J Exp Clin Cancer Res 29: 80.

Hugo, H., M. L. Ackland, T. Blick, M. G. Lawrence, J. A. Clements, E. D. Williams and E. W. Thompson (2007). "Epithelial--mesenchymal and mesenchymal--epithelial transitions in carcinoma progression." J Cell Physiol 213(2): 374-383.

Ito, T., B. Zimdahl and T. Reya (2012). "aSIRTing control over cancer stem cells." Cancer Cell 21(2): 140-142.

Jemal, A., R. Siegel, J. Xu and E. Ward (2010). "Cancer statistics, 2010." CA Cancer J Clin 60(5): 277-300. 
Ji J, Zhang Y, Redon CE, Reinhold WC, Chen AP, Fogli LK, et al. (2017) Phosphorylated fraction of H2AX as a measurement for DNA damage in cancer cells and potential applications of a novel assay. PLoS ONE 12(2): e0171582.

Kang, Y. and J. Massague (2004). "Epithelial-mesenchymal transitions: twist in development and metastasis." Cell 118(3): 277-279.

Karlsson, M.C., Gonzalez, S. F., Welin, J. Fuxe, J (2017).Epithelial-mesenchymal transition in cancer metastasis through the lymphatic system. Mol Oncol. 11(7):781-791.

Kasimir-Bauer, S., O. Hoffmann, D. Wallwiener, R. Kimmig and T. Fehm (2012). "Expression of stem cell and epithelial-mesenchymal transition markers in primary breast cancer patients with circulating tumor cells." Breast Cancer Res 14(1): R15.

Kidd, M. E., D. K. Shumaker and K. M. Ridge (2014). "The role of vimentin intermediate filaments in the progression of lung cancer." Am J Respir Cell Mol Biol 50(1): 1-6.

Kwok, W. K., M. T. Ling, T. W. Lee, T. C. Lau, C. Zhou, X. Zhang, C. W. Chua, K. W. Chan, F. L. Chan, C. Glackin, Y. C. Wong and X. Wang (2005). "Up-regulation of TWIST in prostate cancer and its implication as a therapeutic target." Cancer Res 65(12): 5153-5162.

Lee, T. K., R. T. Poon, A. P. Yuen, M. T. Ling, W. K. Kwok, X. H. Wang, Y. C. Wong, X. Y. Guan, K. Man, K. L. Chau and S. T. Fan (2006). "Twist overexpression correlates with hepatocellular carcinoma metastasis through induction of epithelial-mesenchymal transition." Clin Cancer Res 12(18): 5369-5376. 
Leptin, M. (1991). "twist and snail as positive and negative regulators during Drosophila mesoderm development." Genes Dev 5(9): 1568-1576.

Liu, S., C. Ginestier, S. J. Ou, S. G. Clouthier, S. H. Patel, F. Monville, H. Korkaya, A. Heath, J. Dutcher, C. G. Kleer, Y. Jung, G. Dontu, R. Taichman and M. S. Wicha (2011). "Breast cancer stem cells are regulated by mesenchymal stem cells through cytokine networks." Cancer Res 71(2): 614-624.

Massagué, J., Batlle E., Gomis , R. G. (2017) Understanding the molecular mechanisms driving metastasis. Cancer metastasis 11(1):3-4.

Mani, S. A., W. Guo, M. J. Liao, E. N. Eaton, A. Ayyanan, A. Y. Zhou, M. Brooks, F. Reinhard, C. C. Zhang, M. Shipitsin, L. L. Campbell, K. Polyak, C. Brisken, J. Yang and R. A. Weinberg (2008). "The epithelial-mesenchymal transition generates cells with properties of stem cells." Cell 133(4): 704-715.

Mitchell, K. E., M. L. Weiss, B. M. Mitchell, P. Martin, D. Davis, L. Morales, B. Helwig, M. Beerenstrauch, K. Abou-Easa, T. Hildreth, D. Troyer and S. Medicetty (2003). "Matrix cells from Wharton's jelly form neurons and glia." Stem Cells 21(1): 50-60.

Moons, K. G. M., Royston,P., Vergouwe, Y., Grobbee, D. E., Altman, D. G., Prognosis and prognostic research: what, why, and how? BMJ 2009;338:b375.

Mueller, M. M. and N. E. Fusenig (2004). "Friends or foes - bipolar effects of the tumour stroma in cancer." Nat Rev Cancer 4(11): 839-849.

Nowell, P. C. (1976). "The clonal evolution of tumor cell populations." Science 194(4260): 23-28. 
Orimo, A., P. B. Gupta, D. C. Sgroi, F. Arenzana-Seisdedos, T. Delaunay, R. Naeem, V. J. Carey, A. L. Richardson and R. A. Weinberg (2005). "Stromal fibroblasts present in invasive human breast carcinomas promote tumor growth and angiogenesis through elevated SDF-1/CXCL12 secretion." Cell 121(3): 335-348.

Radisky, D. C., D. D. Levy, L. E. Littlepage, H. Liu, C. M. Nelson, J. E. Fata, D. Leake, E. L. Godden, D. G. Albertson, M. A. Nieto, Z. Werb and M. J. Bissell (2005). "Rac1b and reactive oxygen species mediate MMP-3-induced EMT and genomic instability." Nature 436(7047): 123-127.

Razzak, A. R., N. U. Lin and E. P. Winer (2008). "Heterogeneity of breast cancer and implications of adjuvant chemotherapy." Breast Cancer 15(1): 31-34.

Reya, T., S. J. Morrison, M. F. Clarke and I. L. Weissman (2001). "Stem cells, cancer, and cancer stem cells." Nature 414(6859): 105-111.

Rubin, M. A., N. R. Mucci, J. Figurski, A. Fecko, K. J. Pienta and M. L. Day (2001). "E-cadherin expression in prostate cancer: a broad survey using high-density tissue microarray technology." Hum Pathol 32(7): 690-697.

Russo, J. and I. H. Russo (2004). "Development of the human breast." Maturitas 49(1): 2-15.

Sheridan, C., H. Kishimoto, R. K. Fuchs, S. Mehrotra, P. Bhat-Nakshatri, C. H. Turner, R. Goulet, Jr., S. Badve and H. Nakshatri (2006). "CD44+/CD24- breast cancer cells exhibit enhanced invasive properties: an early step necessary for metastasis." Breast Cancer Res 8(5): R59.

Soon, P. S., E. Kim, C. K. Pon, A. J. Gill, K. Moore, A. J. Spillane, D. E. Benn and R. C. Baxter (2013). "Breast cancer-associated fibroblasts induce epithelial-to-mesenchymal transition in breast cancer cells." Endocr Relat Cancer 20(1): 1-12. 
Sorlie, T., Y. Wang, C. Xiao, H. Johnsen, B. Naume, R. R. Samaha and A. L. Borresen-Dale (2006). "Distinct molecular mechanisms underlying clinically relevant subtypes of breast cancer: gene expression analyses across three different platforms." BMC Genomics 7: 127.

Soule, H. D., J. Vazguez, A. Long, S. Albert and M. Brennan (1973). "A human cell line from a pleural effusion derived from a breast carcinoma." J Natl Cancer Inst 51(5): 1409-1416.

Thiery, J. P. (2002). "Epithelial-mesenchymal transitions in tumour progression." Nat Rev Cancer 2(6): 442-454.

Troyer, D. L. and M. L. Weiss (2008). "Wharton's jelly-derived cells are a primitive stromal cell population." Stem Cells 26(3): 591-599.

Uccelli, A., L. Moretta and V. Pistoia (2008). "Mesenchymal stem cells in health and disease." Nat Rev Immunol 8(9): 726-736.

Wang, Y. K. and Z. Q. Huang (2005). "Protective effects of icariin on human umbilical vein endothelial cell injury induced by $\mathrm{H} 2 \mathrm{O} 2$ in vitro." Pharmacol Res 52(2): 174-182.

Watters, G. P., D. J. Smart, J. S. Harvey and C. A. Austin (2009). "H2AX phosphorylation as a genotoxicity endpoint." Mutat Res 679(1-2): 50-58.

Wells, A., C. Yates and C. R. Shepard (2008). "E-cadherin as an indicator of mesenchymal to epithelial reverting transitions during the metastatic seeding of disseminated carcinomas." Clin Exp Metastasis 25(6): 621-628. 